\title{
La hidalguía a fines del Antiguo Régimen. Los Apuntamientos del granadino Antonio de Orejón y Haro: estudio y edición
}

\author{
LUIS Díaz dE LA GUARDIA Y LÓPEZ* \\ Universidad de Granada
}

\begin{abstract}
The Hidalguía at the End of the Ancien Régime. The Apuntamientos by Granada-born Antonio de Orejon y Haro: Study and Edition
\end{abstract}

\section{RESUMEN}

La finalidad principal de este artículo es el estudio y la edición de un raro libro, por sus escasos ejemplares conocidos - tres señaló F. Aguilar Piñal en su Bibliografía del siglo XVIII-y quizá también singular por su contenido: un tardío formulario de hidalguía (1795), que siguiendo el estilo de la Real Chancillería de Granada es un breve compendio, pero muy completo, en el que se otorga especial importancia a la práctica más común entre la jurisdicción

chancilleresca granadina del XVIII: el llamado pleito sumario de hidalguía -expediente instruido para, sin contencioso, en una localidad o comarca, dar legítimamente estado de hidalgo a un sujeto. Pero relevancia que no fue excusa para desarrollar en él, también, el proceso que vino a denominarse pleito pleno de hidalguía, el verdadero litigio que buscó, en Derecho, demostrar o no la nobleza castellana. Una obra completa en su formulario, breve y singular, cuyo autor fue don Antonio de Orejón y Haro y que tiene por título el de Apuntamientos sobre la hidalguía y colección de fórmulas para

\section{ABSTRACT}

The purpose of this paper is to study and publish a book that is a rarity due to the limited number of existing copies -three, stated F. Aguilar Piñal in his Bibliografía of the 18th Century - and also, perhaps, due to its unique content: a late collection (1795) of legal forms on matters pertaining to hidalguía, or the status of hidalgo, the lowest form of Spanish nobility in the Middle Ages. It is a brief but very detailed compendium which, in the judicial style of the Real Chancilleria of Granada, gives particular importance to the court practice most commonly performed by that higher court in the 18th Century: the so-called summary hidalguía proceeding; -a prior hearing, without litigation, in a locality or region, to give an individual the legitimate status of hidalgo. Notwithstanding its relatively minor interest, the compendium also develops a process known as the full hidalguía proceeding, the actual litigation by which Castilian nobility was proven in Law. It is a very complete work, brief and unique, by Antonio de Orejón y Haro, entitled Apuntamientos sobre la hidalguía

* Universidad de Granada. Facultad de Derecho. Depto. Derecho Internacional Privado e Historia del Derecho. Plaza de la Universidad, 1. 18071-GRANADA. e-mail: Idiazdelaguardia@ugr.es 
todos los recursos de esta naturaleza, con la instrucción que debe dirigir los de los extranjeros, conforme a la práctica que observa la Sala de los señores Alcaldes de los Hijosdalgo de la Real Chancillería de Granada. Artículo, pues, que busca la reedición, pero también el estudio del autor, de la obra y de la temática de este

libro.

PALABRAS CLAVE: Literatura jurídica española / Corona de Castilla / Real Chancillería de Granada / siglo XVIII / Nobleza / Hidalguía / Pleitos de hidalguía / Antonio de Orejón y Haro y colección de fórmulas para todos los recursos de esta naturaleza, con la instrucción que debe dirigir los de los extranjeros, conforme a la práctica que observa la Sala de los señores Alcaldes de los Hijosdalgo de la Real Chancillería de Granada. This paper, therefore, seeks the publication of a new edition of the book, and also further research on the book's author, his work and the topic involved.

\section{KEYWORDS:}

Spanish legal literature / Crown of Castile /Real Chancillería of Granada / 18th Century / Nobility / Hidalguía / Hidalguía proceedings / Antonio de Orejón y Haro

Se presenta en este artículo una obra jurídica menor y casi desconocida, los Apuntamientos sobre la hidalguía y colección de fórmulas para todos los recursos de esta naturaleza, con la instrucción que debe dirigir los de los extranjeros, conforme a la práctica que observa la Sala de los señores Alcaldes de los Hijosdalgo de la Real Chancillería de Granada (editada en 1795), aunque ha sido citada recientemente por algunos estudiosos de la Chancillería de Granada. Obra menor y que, sin embargo, reúne en sí una serie de peculiaridades que la hacen digna de estudio y edición ${ }^{1}$.

Quizá sea uno de sus valores más destacados, a través de su concreción, el que aún hoy pueda ser útil a historiadores, nobiliaristas y genealogistas, en fin, útil a todos aquéllos que se acerquen a la nobleza española moderna y quieran comprender su importante vertiente jurídica -casi su esencia- sin necesidad de espigar entre discursos, con frecuencia enrevesados y fantasiosos, las verdades fundamentales del objeto de estudio².

\footnotetext{
1 La primera noticia que hallé de esta obra fue en Francisco AGUILAR PIÑAL: Bibliografía de autores españoles del siglo XVIII. Tomo VI, CSIC, Madrid, 1991, p.177. Y lo utilicé ya en Luis DÍAZ DE LA GUARDIA LÓPEZ: «Aburguesamiento de la nobleza media y baja en Castilla: los pleitos de hidalguía», en Luis Miguel ENCISO RECIO (coord.): La Burguesía Española en la Edad Media, tomo I, Fundación Duques de Soria / V Centenario del Tratado de Tordesillas / Universidad de Valladolid, Valladolid, 1996, pp. 517-531. De igual modo la obra de Orejón y Haro que nos ocupa ha sido citada por Inés GÓMEZ GONZÁLEZ.: La justicia, el gobierno y sus hacedores. La Real Chancillería de Granada en el Antiguo Régimen, Editorial Comares, Granada, 2003, p.165. De los tres ejemplares conocidos y citados por Francisco Aguilar Piñal, el que este autor sitúa en Málaga ha desaparecido, mientras que el de la Universidad de Granada está incompleto y sólo se encuentra en perfectas condiciones el custodiado en la Biblioteca de El Escorial. De la utilización de ambos ejemplares, el granadino y el escurialense, se ha servido el presente estudio y edición.

2 Archivo Histórico Nacional (en adelante AHN), Consejos, Leg. 5558, pz. 108. Pese a la semejanza y monotonía de los discursos tradicionales sobre la nobleza, algunos sorprenden aún, como el realizado por el doctor don Bernardo del Campo, catedrático de Filosofía en el seminario conciliar de San Jeróni-
} 
Con lo dicho no se afirma aquí que obras como las de Arce de Otalora, García de Saavedra o Tiracquel (nuestro Tiracuelo) hayan sido superadas por la que se edita ahora, ni que ellas sean desde Orejón obras secundarias con respecto a ésta y que su lectura pueda ser evitada con los Apuntamientos. Ni Antonio de Orejón lo pretendió, ni estaba entre sus fines, ni, seguramente, entre sus posibilidades. Es más, olvidando por ahora obras y estilos y comparando unos y otros discursos, la calidad y profundidad que se puede hallar en Saavedra, Otalora, etc., no se encontrará nunca en Orejón, pero sí estará en él, por contra, la presentación límpida, casi sin comentario alguno, de las distintas fórmulas jurisdiccionales que acompañan a la hidalguía española ante la justicia regia, de modo que a través de una rápida lectura de las mismas, tanto antaño como ogaño, se puede comprender sin duda la realidad jurisdiccional de la hidalguía española, cuando menos bajo la Casa de Borbón, hasta el inicio del reinado de Isabel II en el que desaparecieron estas prácticas forenses que tenían como fundamento el reconocimiento o no de un individuo como hidalgo.

\section{EL AUTOR}

Fue don Antonio de Orejón y Haro uno de los abogados, de entre muchos, que se criaron y nacieron alrededor de la Universidad y de la Chancillería de la ciudad de Granada durante la Edad Moderna. Uno entre muchos y así, anónimamente, hubiera pasado su vida si no fuese por su vertiente de autor, pues quizá lo único que lo singulariza sea su afán de escritor de temas jurídicos y especialmente el haber escrito el que ocupa el presente trabajo: Apuntamientos sobre Hidalguía.

El autor de esta breve obra, don Antonio de Orejón, nació el año de mil setecientos treinta y cuatro. Era el fruto del matrimonio habido entre don Domingo Orejón Dávila Haro y Arce y doña María Josefa de Almendros y del Bosque, que por entonces tenían casa en la parroquia de la Encarnación de Granada (más tarde conocida como Santos Justo y Pastor) ${ }^{3}$.

mo de Burgos, obra de fines del XVIII titulada Plan de educación para la juventud noble hasta los 25 años. En la que se contenían tales afirmaciones, como las referentes a la búsqueda del nacimiento de buenos y dignos nobles, que al censor de la obra, el licenciado Manuel Joaquín de Condado, no le quedó otro remedio, ante ellas, que escribir: «Más ridículo es todavía, señalando los remedios para prevenir este mal, aún antes que los niños salgan a la luz del mundo y previniendo que se observen al tiempo de la procreación aquellas leyes que la naturaleza prescribe a los consortes, y poner como una de ellas atender particularmente a la acción del tiempo en que sopla el cierzo y el cielo está despejado. Célibe por mi estado, no he podido experimentar quánto influxo tenga el soplo de cierzo en la generación de los hijos. Pero bien sé que ésta y semejantes lecciones ni son propias del siglo en que vivimos, ni bastante decentes, ni dignas de otra acogida, que la de la fábula rancia y vulgar de que las yeguas se empreñaban del viento».

3 Archivo de la Parroquia de los Santos Justo y Pastor, Bautismos, libro 14, fol. 16: «En la ciudad de Granada, en diez y nueve días del mes de abril de mil seteçientos y treinta y quatro años, yo el padre Françisco Luengo, del Señor San Gregorio, de permiso de don Benito Rodríguez Blanes, baptizé a Antonio Esmerejildo Joseph, hixo de don Domingo Orejón y doña Josepha (digo doña María Josepha) de Almendros. Abuelos paternos don Juan Orejón y doña Clara Franzisca de Arze y maternos don Blas de Al- 
Pertenecía don Antonio de Orejón y Haro y de Almendros a una familia oriunda de Granada, de calidad noble, y enclavada en lo que se podría denominar como la clase media de la ciudad. Familia que poco a poco iría introduciéndose en el mundo de los pleitos y de la abogacía ${ }^{4}$.

Ya el padre de don Antonio, Domingo de Orejón y Haro, un hidalgo nacido también en la ciudad del Genil en $1711^{5}$, estudió leyes en la Universidad de Granada, para, más tarde, ejercer varios años de pasantía. Así lo atestigua la certificación expedida en 1745 por el licenciado y abogado granadino don Francisco Sánchez Navas, en la que se declara lo siguiente de Domingo Orejón Dávila y Haro:

«[...] había asistido en su estudio más tiempo de ocho años. Y algunos de ellos ha servido la pasantía de pluma. Y que en año en uso se está ejercitando de presente, y también que ha concurrido a la Academia de práctica que presido, consiguiendo en uno y en otro grande adelantamiento» ${ }^{6}$.

Miembro del Colegio de Abogados granadino desde 23 de mayo de $1746^{7}$, no parece que su carrera en esta Corte fuera muy sobresaliente pues tras varios años

mendros Salazar y doña Manuela del Bosque y Cisneros. Fue su compadre don Antonio Montalvo, alcaide de la fortaleça de Torres Mermejas [sic]. Y testigos el lizenziado don Franzisco Sánchez, lizenziado don Juan Diego Matheos y don Antonio Pablos Ximénez, veçinos de Granada. Don Benito Rodríguez Blanes (Firmado y rubricado). Franzisco Luengo, de los clérigos menores (Firmado y rubricado)».

${ }^{4}$ AHN, Consejos, Leg. 10004. Sirva como ejemplo de su antigua nobleza y de la ligazón de este linaje y familia con Granada, el siguiente documento a nombre del padre del autor de los Apuntamientos: «Sacra Real Magestad. Señor. Don Domingo Orejón Dávila y Haro, abogado de los del llustre Colegio de la Real Chancillería de Granada, vezino de la ciudad de Loxa, de aquel Reyno, puesto a las Reales plantas de Vuestra Majestad, con el más profundo rendimiento, dice: que para sus intereses nezesita que el archivista de Simancas le dé zertificazión de la merced que Sus Magestades Cathólicas se sirvieron hazer a Hernando Orejón Dávila, su sexto abuelo, que de capitán de Guardas Viejas de Castilla vajó de la ciudad de Ávila de los caballeros en servizio de dichas Magestades a la conquista de Granada. Heredándole en el término de Santa $\mathrm{Fe}$, al pago de Barrasa, con diferentes marxales de tierra en el año de mil quatrocientos noventa y dos, en los meses mediatos al de henero en que se entregó dicha ciudad. Cuia merzed pasó ante Hernando de Zafra, su secretario. Y para conseguirlo, ocurre el suplicante a la piedad de Vuestra Magestad, a quien suplica se sirva mandarle despachar su Real Cédula para que dicho archivista le dé la expresada certificazión. Fabor que espera de la piedad de Vuestra Magestad, por cuia importante vida queda el suplicante pidiendo a Dios la dilate por siglos para amparo de sus vasallos y bien de la Monarquía. Loxa y marzo, 21 de 1784. Domingo Orejón y Haro (Firmado y rubricado)", petición que, por cierto, obtuvo la satisfactoria aprobación el 30 de marzo de 1784.

5 Archivo de la Real Chancillería de Granada, (en adelante ARChG), Real Acuerdo, 321-4295-4. «En dos días del mes de marzo de mil setezientos y onze años, a mi ruego, el padre fray Joseph Bernardo de Granados, religioso de su convento de Capuchinos de esta ciudad, baptizó en esta parrochia del señor San Andrés, a Domingo Bernardo Joseph, hixo de don Juan de Orejón y Haro y doña Clara Franzisca de Arze, su muger, naturales de esta ciudad. Abuelos paternos don Fernando Orejón, natural de esta dicha ciudad, y doña Petronila de León y Santillán, natural de Alhendín. Maternos don Domingo de Arze y Arizcum, natural de la villa de Arizcum, Reino de Navarra y valle de Basteri, y doña Beatriz de Siles y Morales, natural de la villa de Guadahortuna. Fueron compadres el dicho don Domingo de Arze, su abuelo, y doña Luisa de Orejón y Arze. Y testigos don Franzisco de Andújar y Toledo, don Cristóbal Ximénez y don Franzisco Gómez Freyle, vezinos de esta ciudad. Don Luis Ximénez de la Zerda, (Firmado y rubricado). Fray Joseph Bernardo de Granados, (Firmado y rubricado)».

6 Ibídem.

7 ARChG, Real Acuerdo, 321-4295-4. En marzo de 1745, don Domingo Orejón de Haro solicitó la recepción de abogado al Real Acuerdo de la Real Chancillería de Granada, lo que pasó a consideración del entonces oidor don José de Hita. Transcurridos los trámites pertinentes el Real Acuerdo, con fecha 
de residencia en Granada, el padre del autor terminaría avecindándose en la cercana ciudad de Loja, en donde transcurrió el resto de su vida ejerciendo la abogacía y otras ocupaciones públicas y privadas.

La elección de Loja no fue arbitraria. La familia Orejón tenía relación con la expresada ciudad al menos desde 1731, pues desde ese año, uno de ellos, llamado Juan de Orejón y Haro, era escribano de Cabildo y del número ${ }^{8}$. En Loja, el padre del autor, don Domingo de Orejón abrió su bufete y pasó a convertirse en el abogado de referencia de la ciudad, llegando a ser el propietario de los cortijos -nada despreciables en cuanto a capacidad- de Escalona y Tajarilla, sitos en el término jurisdiccional lojeño. De su acomodada posición da también cuenta el que en 1757 aparezca habitando una casa principal en la calle de Montoya, en la parroquia de Santa Catalina ${ }^{9}$.

Junto a sus actividades particulares como labrador y como abogado, don Domingo asesoró a su concejo e incluso vino a ocupar oficios en él como el de síndico procurador de Loja, lo que fue varios años, entre ellos en 1775, 1776 ó $1781^{10}$.

No es de extrañar que en un ambiente ligado a la jurisprudencia, don Antonio de Orejón y Haro, el autor que nos ocupa, decidiera seguir los pasos de su padre y se dedicase al cultivo del Derecho en la Universidad de Granada. Allí, no como colegial sino como simple manteísta, estudiará leyes:

«Nos los chatedráticos de Cánones y Leyes de esta Ynperial Universidad de Letras de esta ciudad, zertificamos que don Antonio Orejón, natural de ésta y vezino de la de Loxa, ha asistido a nuestras chátedras el tiempo prevenido por las Constituciones de dicha Universidad. Argüiendo y defendiendo las questiones que se le han puesto y encargado. Y para que conste, damos la presente en Granada en quinze días del mes de octubre de mil setezientos cinquenta y uno. Doctor don Jo-

de 20 de mayo de 1746, le admitió a examen, dándole por tema -a sugerencia del oidor decano don Antonio de Hinojosa- el pleito del que era relator el licenciado Molina, que versaba sobre el enfrentamiento judicial existente entre el veinticuatro de Sevilla don José Badillo, como marido y conjunta persona de doña Teresa Enríquez, y don Juan Torres Enríquez López de Padilla, vecino de Jerez, sobre el vínculo de tercio y quinto que fundara Rafael Enríquez. Superado positivamente este fielato, el Acuerdo de la Real Chancillería acogió y juramentó como abogado de su Colegio a Domingo de Orejón y Haro el 23 de mayo de 1746, el cual pagó al día siguiente por su título la cantidad de sesenta y seis reales de media anata.

8 Archivo Municipal de Loja (AML), Varios, Leg. 121, pz. 37 . El 17 de marzo de 1731, don Juan de Feloaga, oidor de la Real Chancillería de Granada y del Consejo, así como juez privativo de la Comisión de Oficios Titulares del Reino de Granada, hacía saber al concejo de la ciudad de Loja que ante él se había presentado «Juan Orejón y Haro, escribano de Su Magestad, haciendo relación de que ya tenía noticia del despacho que se le avía librado para el uso y el exercicio de los oficios de Cabildo y del Número de la dicha ciudad de Loxa, que avían bacado por muerte de Manuel Martínez Sillero [...] [por lo que se ordenaba por Feloaga que] Pongan y hagan poner a el dicho Juan de Orejón en la posesión de los oficios de cavildo y número de la dicha ciudad». El teniente de corregidor de Loja, don Pedro José del Rosal, hizo cumplir el despacho antecedente por lo que fue recibido como escribano de la ciudad el 20 de marzo de 1731.

9 AML, Padrones, Leg. 10.

10 AML, Varios, Leg. 140; Leg. 141; y Leg. 145. 
seph de Cuéllar y Morales (Firmado y rubricado). Doctor don Francisco Antonio de Olea (Firmado y rubricado) ${ }^{11}$.

El 21 de octubre de 1751 solicitó del Rector Magnífico se le concediera el grado de bachiller ${ }^{12}$. Cinco días más tarde, vistos certificado e instancia, el 26 de octubre de 1751, el secretario don Nicolás de la Fuente Galindo puso en consideración del rector la petición cursada por don Antonio. Atendiendo la petición el entonces rector, doctor don Luis Sánchez de Molina, ese mismo día, mandó que se le confiriera «el suso dicho grado de bachiller en dicha Facultad que pretende. Y que para ello se zite al señor decano para mañana a las tres de la tarde» ${ }^{13}$. Conseguido este requisito, Antonio de Orejón y Haro dedicose al ejercicio de diferentes pasantías, siendo la última de ellas la que realizó con el abogado don José Ramón Moreno:

«Don José Ramón Moreno, abogado de esta Corte, en el mejor modo que puedo, oy, en toda forma zertifico y juro que el bachiller don Antonio de Orejón y Haro, vezino de esta ciudad, ha asistido con frequenzia diaria a mi estudio y despacho desde principio del año pasado de mil setecientos y zinquenta y cinco hasta de prezedente. En cuio tiempo he advertido su aplicación a la facultad de Leyes y cuidado en desempeñar los varios asumptos de ella que he encargado. Y para que conste doy la presente a su instancia, que firmo en Granada a veinte y dos de febrero de mil setezientos cinquenta y nuebe. Licenciado don Joseph Ramón Moreno (Firmado y rubricado) ${ }^{14}$.

La intención de don Antonio de Orejón no era otra en 1759 que la de ser recibido por la Chancillería como su abogado, al igual que lo había sido en su tiempo su padre:

«Muy poderoso señor. Don Antonio de Orejón y Haro, vezino de esta ciudad, digo: que como consta de la fe de baptismo, título de bachiller y zertificazión de pasantía que presento en devida forma, me hallo graduado de tal bachiller y con la competente edad y pretendo rezevirme por abogado de esta Real Chanzillería. En cuia atenzión a Vuestra Alteza suplico se me admita y reziva, y que para hazer mi lección y oposición se me mande dar pleito en la forma acostumbrada, en que reziviré merzed, etc. Don Antonio Orejón y Haro (Firmado y rubricado)»15.

El 28 de mayo de 1759 se pasaba la documentación presentada por Orejón al oidor de la Chancillería don José María de Alfaro. Por el oidor Hita se le dio para el

11 Archivo de la Universidad de Granada (en adelante AUGr), L-1659-036.

12 AUGr, L-1659-036. «Don Antonio Orejón, natural de esta ziudad y vezino de la de Loxa, ante vuestra señoría como más aia lugar, parezco y digo: que io he estudiado en la Facultad de Sagrados Cánones en esta Ymperial Universidad, el tiempo prevenido por las Constituziones de ella, como consta de esta zertificazión, que presento con el juramento nezesario, dada por los catedráticos de dicha Universidad. Y mediante a hallarme apto para rezivir el grado de bachiller en dicha facultad, a vuestra señoría suplico: que haviendo por presentada dicha zertificazión se sirva de mandar se me confiera dicho grado en la forma que es costumbre. Que es justicia que pido, etc. Don Antonio Orejón y Haro (Firmado y rubricado).

13 Ibídem.

14 ARChG, Real Acuerdo, 321-4295-4.

15 Idem. 
examen el pleito de don Cristóbal de Soto Sandoval y Ríos que versaba sobre la sucesión al vínculo fundado por Rodrigo de Soto y del que a la sazón era relator el licenciado Pérez. Llevado a cabo el examen ante el Real Acuerdo el 19 de junio de 1759, por el presidente y oidores, el candidato fue «hallado hávil, capaz y sufiziente por lo que le admitieron y rezivieron por abogado de esta Real Chanzillería y le dieron lizenzia y facultad para que lo pudiese usar y exercer en todo lo a él tocante y subir a los estrados de todas las Salas de ella y a los de los demás tribunales y juzgados". Juramentado y habiendo abonado la cantidad de 106 reales, don Antonio de Orejón y Haro comenzó su carrera de letrado, soñando seguramente no sólo con ocuparse con pleitos sino también con alcanzar puestos de mérito al servicio del Rey ${ }^{16}$.

No se ha encontrado relación entre el cabildo de Loja, su ciudad, y don Antonio de Orejón, lo que induce a pensar que dedicó toda su vida al desempeño de la práctica jurídica en los diferentes tribunales del reino de Granada: perteneció al Colegio de Málaga, igualmente al Colegio de Abogados de la Real Chancillería de Granada y al fin consiguió titularse de abogado de los Reales Consejos.

\section{PRIMEROS INTENTOS LITERARIOS}

Tardará don Antonio de Orejón y Haro en decidirse a escribir y publicar, no será hasta 1785 que esto ocurra. Es pues un hombre maduro, de 51 años, un abogado experto que está imbuido en las corrientes jurídicas de su época, corrientes que impulsan -en cuanto se tenga casi la menor inquietud-a publicar, a reformar por medio de libros, a corregir lo pasado y gracias a ello a actualizar ${ }^{17}$.

16 ARChG, Real Acuerdo, 321-4295-4. Juramento que realizó ante el Real acuerdo, comprometiéndose «por Dios y una señal de Cruz, en forma de Derecho, de defender el misterio de la limpia y pura conzepción de María Santísima nuestra Señora. Usar vien y fielmente el ofizio de abogado, guardar las leyes y pregmáticas de Su Magestad, ordenanzas, autos acordados y resultas de visita de esta Real Chancillería. No llevar derechos demasiados y, a los pobres, ningunos. Y en todo cumpla con el referido empleo y si lo hiziese Dios nuestro Señor le aiudase y si no se lo demandase».

17 AHN, Consejos, Leg. 5558, pz. 73. Sirvan de muestra de estos sentimientos, de estas actitudes comunes a muchos letrados de fines del siglo XVIII, las palabras que el conde de la Cañada, presidente del Consejo, dirigía a sus subordinados que debían otorgar la licencia de publicación: «Muy poderoso señor La necesidad del estudio de las leyes del Reyno en los que han de juzgar y administrar justicia, la dificultad de adquirir cumplidamente sus conocimientos por los difusos volúmenes en que están recopiladas sin el buen orden sucinto y claro que debía desearse, la imposibilidad de recivir estas enseñanzas en las Universidades como está mandado y la mayor que concevía yo en el uso práctico de lo que disponen las leyes, me hicieron pensar muchos días en los medios que pudieran ser más oportunos para facilitar a los letrados y a los jueces el conocimiento más exacto de las mismas leyes reales y el uso práctico de sus disposiciones y elegí con estos objetos escrivir esta obra que tengo el honor de presentar al Consejo, dividida en tres partes, que comprehenden treinta y un capítulos, como manifiesta su índice y en ellos se trata por su orden de los juicios civiles en todos sus trámites ordinarios y extraordinarios hasta acabarlos en su execución. Aunque empecé a escrivir esta obra con unas ideas pribadas que asegurasen la instrucción de que yo necesitaba para llenar en lo posible los ministerios y encargos con que la piedad del Rey se dignó honrarme, me excitaron otros respetos a que la imprima y publique por la utilidad que producirá según y en los términos que explican los autores de las censuras que presenté al Consejo y en que fundó la licencia que se dignó concederme para imprimir el tratado de las Fuerzas en un tomo, con 
Preciso, Orejón no es un ilustrado, tampoco un personaje con grandes intenciones reformadoras, no es un revolucionario o un individuo que pueda estar en cierta forma 'contaminado' de lo que empezaba a filtrarse de allende nuestras fronteras. Él no buscó reformas sorprendentes, ni sus escritos son diatribas directas que aborden los grandes temas políticos. Él optó por campos más modestos sobre los que escribir y corregir, más concretos, aunque dentro de su concreción, muy amplios.

Es, en definitiva, un modestísimo heredero de la jurisprudencia española y castellana. Orejón, como otros del siglo XVIII está influido por estos dos vectores, el de la reforma desde arriba, propia de las ideas políticas del momento que le tocó vivir y por otro lado está influenciado y sumergido en otro, un vector complejo, sí, pero uno que no es otro que el conformado por la herencia y evolución de la jurisprudencia española.

Presente y envuelto en esta coyuntura, buscando fama, honra y quizás, también, mayor riqueza, Antonio de Orejón y Haro ideó una obra completa destinada a aquéllos que se acercaren a los estrados. Pretendió crear un gran cuerpo teóricopráctico que fijase los procesos y su práctica. Una obra que sirviera en todos los tribunales, obra, por tanto, destinada a constituirse en una referencia fundamental. Escrito que tituló Jurisprudencia universal teórico práctica. Compendio útil y formulario completo de los juicios civil ordinario, ejecutivo y criminal en todas instancias y recursos. Con el de la segunda suplicación, el de fuerza, el de nulidad de elecciones y algunos provisionales.

Terminado su libro, su Jurisprudencia universal, pidió la preceptiva licencia de publicación. Para ello y en su nombre, el procurador José Antonio Sanz solicitaría ante el Consejo el imprimatur. Las cosas no saldrán como apetecía Orejón y Haro. El 19 de agosto de 1785 comienza su particular calvario cuando se manda que su obra sea remitida a la censura del Colegio de Abogados de la villa y Corte. Hasta el 2 de marzo de 1786 no se llevará a efecto la orden. Habían pasado ya casi siete meses cuando Antonio Orejón y Haro por medio de nuevo procurador, Antonio de Parga, pregunta al Consejo por el destino de su obra, de la que no había obtenido todavía la licencia de impresión.

El autor carecía de apoyos. El Consejo no hizo nada hasta que el 22 de febrero de 1786 recordó al Colegio de Abogados la orden que se le había dado sobre la Jurisprudencia Universal. No hay respuesta. Temiendo Antonio Orejón que la censura no se llegara a dar, cayendo el encargo en el olvido, o que la respuesta del Colegio fuera negativa, por medio de su procurador Parga, solicitó que los ori-

las formalidades que contiene la certificación de don Pedro Escolano de Arrieta, dada en tres de diciembre del año próximo, y deseando hacerlo al mismo tiempo de la enunciada obra, con el título de Apuntamientos y observaciones prácticas de los juicios civiles, que mereció la misma aprobación y censura que la anterior de las Fuerzas. A vuestra alteza suplico se digne a concederme su permiso y licencia para imprimir y publicar conforme a las leyes esta nueba obra en que reciviré especial gracia. Madrid, 17 de enero de 1793. El conde de la Cañada». La licencia de publicación se dio el 21 de enero de 1793. 
ginales le fueran devueltos ya que como adujo el procurador «su parte desea adicionar la obra que tiene presentada con el título de Jurisprudencia Universal teórica y práctica, a fin de que salga al público como corresponde» ${ }^{18}$. El silencio es lo que obtiene, de nuevo el Consejo dilató su respuesta ${ }^{19}$.

No será hasta el 26 de noviembre de 1787 cuando actúa el Consejo exigiendo al Colegio de Madrid que devuelva la obra y que ésta se le entregue a Orejón. Ante la nueva orden el Colegio respondió. Y lo hizo el 15 de enero de 1788, gracias a una carta dirigida a don Pedro Escolano de Arrieta y firmada por don Juan Antonio Avella Menéndez.

«Muy señor mío: en Junta de 13 del corriente di cuenta del papel de primero de diziembre próximo anterior en que usted me participa haber acordado el Consejo que éste mi Colegio debuelba por su mano la obra que de su real orden remitió a censura en 25 de agosto de 1785, titulada Jurisprudencia Universal Teórica y Práctica. Y aviéndoos dado cuenta también en ella de la que avían formado y dirigido en el día 3 de este mes los yndividuos comisionados por el Colegio, convencida la Junta de que si se dedicase a reconocer por sí la obra y corregir o adicionar según la costumbre la referida censura, faltaría a la pronta ejecución de esta real orden, ha acordado debolver al Consejo en su obedecimiento la censura original de los comisionados con dicha obra y que pidiese yo a usted, como lo hago, a su nombre, que quiera ponerlo a todo en la superior consideración de Su Alteza. Nuestro Señor guarde a usted muchos años. Madrid 15 de enero de 1788. Don Juan Antonio Avella Menéndez (Firmado y rubricado). Señor don Pedro Escolano de Arrieta» 20 .

18 AHN, Consejos, Leg. 5551-3.

19 AHN, Consejos, Leg. 11277, pz.18. La necesidad de apoyos era fundamental, es evidente, y esto tanto para superar censores como para obtener ayudas económicas. Del goce de ayudas se sirvieron muchos juristas españoles para conseguir publicar obras meritorias que sin auxilio nunca hubiesen visto la luz. Por ejemplo Bartolomé Agustín Rodríguez de Fonseca, autor del apreciado y muy divulgado Digesto teórico-práctico o Recopilación de los Derechos común, real y canónico por los libros y títulos del Digesto, una vez comenzada la publicación de su obra y viéndose falto de recursos, primero solicitó al conde de Floridablanca, en 1786, un oficio y esto en virtud de la buena recepción de su obra incial: «En atención a que esta obra ha sido y es de la aceptazión pública y del Consejo, como aparece de haver consultado a Su Majestad en favor del suplicante [...] Las gacetas de Ytalia y Olanda hacen honrosa memoria de esta obra y generalmente se desea su conclusión de su impresión por considerarse muy útil a público». Segundo, más tarde, conseguido el favor del conde, Floridablanca mismo escribía lo siguiente al Jefe de la Imprenta Real don Francisco Fernández de Rávago: «Dígame vuestra señoría si se podrá auxiliar a don Bartolomé Rodríguez de Fonseca para la publicación de su obra del Digesto teórico-práctico por el medio que propone en la representación adjunta. Sin perjuicio de la regla bajo que se maneja la Real Imprenta. Y no siendo posible indíqueme vuestra señoría medio equivalente. Dios guarde, etc». Falto otra vez de dinero volvía en 1789 a solicitar fondos del conde de Floridablanca: «Excmo. Señor. Don Bartolomé Rodríguez de Fonseca, autor del Digesto Teórico Práctico que se imprime en la Ymprenta del Rey de quenta de sus fondos con calidad de reintegro de la venta de la obra, debiendo quedar el sobrante a beneficio del autor, pide a vuestra excelencia que se sirba mandar construyan cuanto antes la impresión y que atendiendo al gran número de subscriptores que han en esta obra, a la qual los gremios esperan en conclusión para tomar el número de exemplares que importe 2.000 pesos, para remitirlos a América, a que su hermano don Alfonso Rodríguez afianza 200 ducados por en el caso de que la imprenta no pueda hacerse pago de los gastos. Y ya que ha consumido más de 10.000 pesos en la impresión de los tres primeros tomos y alimentos en 18 años que ha empleado en escribir la obra, se le den desde ahora trescientos ducados anuales a quenta de la misma obra».

20 AHN., Consejos, Leg. 5551-3. 
La obra de Orejón y Haro fue ambiciosa. Su Jurisprudencia estaba dividida en dos partes:

Una primera, más teórica y doctrinal, en donde el autor desarrolló todos sus conocimientos sobre litigios y procedimientos, sobre el arte del foro, así como expresó sus opiniones, unas propias y otras formadas en base a autores y, como no, igualmente fundamentadas en la ley. Autores ya clásicos como Gregorio López, Covarrubias, Hevia Bolaños, Bovadilla, Larrea, Cevallos, Sarmiento, Gutiérrez, González, Gómez, Acevedo, etc., así como padres y doctores de la Iglesia, por tanto nada distinto a las corrientes clásicas de la jurisprudencia española insertas en la metodología del mos italicus.

La segunda parte, por contra, entraba a fondo en la práctica y los formularios, desarrollando proceso por proceso, en busca de facilitar su uso por los prácticos del Derecho. Era en fin una obra planteada en la conjunción de la doctrina y los hechos ${ }^{21}$.

Pese a la premura que exigía el Consejo, la obra estuvo en manos del Colegio de Abogados de la Corte para la censura desde 1785 hasta 1788, censura que no se realizó de forma íntegra por el Colegio, el que - no sin cierto descaro tras tres años- consideró que de realizar una revisión profunda se demoraría el cumplimiento de las órdenes del Consejo, dada la extensión de la Jurisprudencia y de lo mucho que tenía por corregir.

Lo cierto es que la obra de don Antonio de Orejón, su gran obra a la que había dedicado tanto y que era la culminación de su madurez profesional, soportó una única censura y un examen poco detenido, sólo el que practicaron los colegiados don Antonio de las Peñas Vigo y Cortés, doctor en Derecho, y el licenciado don Andrés de la Rica, en diciembre de 1787. No fueron benevolentes, ningún elogio o condescendencia: los letrados comisionados se dispusieron «con claridad y dis-

21 Parte práctica no menos importante y fundamental e incluso me atrevería a afirmar que quizá más decisiva que la parte teórica, pues como demostrará en su obra sobre la hidalguía, Orejón es un práctico del Derecho y ése es su enfoque, el del práctico. Como otros muchos juristas españoles de los siglos XVI, XVII y XVIII buscará el perfeccionamiento de la jurisprudencia desde la práctica, desde el día a día del Derecho. Prácticos criticados antes y ahora y seguramente con buenas razones, pero de los que no se debe apartar, al enjuiciarlos, su afán depurador, su afán renovador de realidades obsoletas, y esto por medio precisamente de la práctica. En este sentido diría el consejero y abogado José de Covarrubias «La práctica como algunos se persuaden no es la rutina de lo que hacen frequentemente los jueces, escribanos y demás subalternos de los tribunales, que obran sin principios, sino la exacta aplicación de las leyes a los casos y circunstancias de las especies que se controvierten, ya sea para averiguar la verdad o evitar que se obscurezca, ya sea después de averiguada, terminar en definitiva las contiendas de los litigantes, aplicando la ley al hecho que se disputa. La práctica general abraza la observancia y aplicación de todas las leyes a quantos litigios pueden ofrecerse en los tribunales para su decisión. Pero en particular se limita a las leyes que reglan los trámites y formalidades en el orden judicial para la averiguación de la verdad de los hechos que se niegan o ponen en duda por los litigantes. Esta parte de la legislación es la que trata de asegurar la vida, la honra, la hacienda de cada uno de nosotros y de nuestros conciudadanos. El orden o desorden, la justicia o injusticia, saca su origen de la observancia o inobservancia de estas leyes. Y toda transgresión en ella es la señal precursora de la injusticia o de la tiranía de los tribunales", José de COVARRUBIAS: Plan de disertaciones sobre práctica de tribunales aprobado por la Real Academia de Derecho Español y Público con el título de Santa Bárbara, por don Blas Román, impresor, Madrid, 1792, p.1. 
tinción a expresar los defectos, que en cada una de ellas (de las partes) notamos „22. Así lo hicieron.

En la censura se acusa al autor, en primer lugar y reiteradamente, de una cualidad que no sólo era propia de sus escritos sino de muchos que alcanzaron la publicación: de haber copiado demasiado al pie de la letra a determinados juristas. Pero además se le acusa de hacerlo mal. Así en diferentes epígrafes de su capítulo segundo, dicen los censores

«[...] son hasta quatro, que son copia de lo que expresa el autor de la Curia Filípica [...] pero con la diferencia de que el autor de la presente obra omite especies, que aquél trahe y es útil y aún necesario saberse. Con lo que concurre que siendo la materia de bastante extensión y exigiendo lata explicación, ninguna hace nuestro autor. De modo que por su obra se sabe de la misma materia menos que por la Curia, que dice bien poco de lo que en el asunto conduce saberse ${ }^{23}$.

No fue la única vez que se le acusó de esto. Hablando sobre la inmunidad afirman los comisarios «que todo está copiado del político Bovadilla, libro 2, capítulo 14, desde el número 1 y señaladamente desde el 3 . Y con leer a este autor y al señor Covarrubias [...], se instruie cualquiera a fondo de si la inmunidad local es o no de Derecho Divino, y del origen y principio que tuvo, sin necesidad de impender mucho trabajo y tiempo en buscar y leer los que cita el de la obra que comentamos ${ }^{24}$.

${ }^{22}$ AHN, Consejos, Leg. 5551-3. Defectos que no sólo atañían al estilo o a la jurisprudencia más estricta sino también a las intenciones políticas y religiosas del escritor, y así lo afirma, por ejemplo, don José Miguel de Flores, asesor de Guerra de la plaza y comandancia general de Madrid, en una frase contenida en la cesura de 21 de junio de 1785 relativa al libro que el licenciado José Ledo de Pozo, párroco de Carrecedo en Ponferrada y catedrático de Filosofía, pretendía publicar. En este sentido decía José Miguel de Flores: «la principal obligación de un censor es ver si la obra que se le confía contiene algo contra la religión, las regalías y buenas costumbres», AHN, Consejos, Leg. 5550-26.

${ }^{23}$ AHN, Consejos, Leg. 5551-3.

${ }^{24} \mathrm{AHN}$, Consejos, Leg. 5551-3. Algunas acusaciones más de este tipo están presentes en la censura de 1787. Por ejemplo, al hablar Orejón sobre los mayorazgos se le espeta que todo es «trasunto o copia de lo que en la materia escrivió el señor Roxas de Almansa». AHN, Consejos, Leg. 13382, pz. 17. Acusaciones de asuntos como el plagio, lo innecesario de las citas o la vulgaridad de las mismas son muy comunes incluso en obras que llegaron a publicarse, por ejemplo el autor del Corregidor Perfecto -obra que vio la imprenta y que gozó de cierta fama- el licenciado don Lorenzo Guardiola sufrió la siguiente censura al presentar el manuscrito a las autoridades: "Señor. De orden de Vuestra Majestad y con fecha del día 12 de este mes, pasó el secretario don Juan Francisco Lastriti a esta Real Academia por mano de su presidente don Miguel de Gálvez, vuestro ministro en el Supremo Consejo de Guerra, la disertación de don Lorenzo Guardiola y Sáez, que trata de la Justicia y sus Especies, elogios y virtudes, y cómo deba administrarse en las causas criminales, sin falta a la piedad, con expresión de los daños que es capaz de causar la injusticia y medios de precaverla, a fin de que la Academia informe con exactitud a Vuestra Majestad de su mérito. Y, haviendo examinado atentamente el dictamen de los individuos que comisionó para reconocerla, halla que la disertación referida es una pieza compuesta en la mayor parte de doctrinas generales de autores comunes, vertidas a veces sin discernimiento y otras con oscuridad, hasta el extremo de incidir en la proposición de que el Rey negligente en hacer justicia puede ser privado de la administración del reyno, que sin duda ha sentado copiándola inconsideradamente de Bovadilla. Algunas de las pruevas con que el autor pretende sostener sus proposiciones son mui débiles y tal vez ridículas. Usa principios vulgares para satisfecer varios puntos que se propone tratar. El modo por exemplo de administrar la justicia en las causas criminales, sin faltar a la conmiseración, lo reduce a decir que el corregidor debe ser justo y al mismo tiempo piadoso. Y los medios de precaver la satisface diciendo que el corregidor ha de estar adornado de ciencia y de las virtudes morales y civiles que previenen nuestras le- 
Junto al plagio se recrimina a Orejón y Haro la cita innecesaria de autores, como se acaba de ver, sobre todo se le acusa de esto cuando ya la ley explicita suficientemente bien las materias que trata sin que fuese necesario mayor abundamiento, pero además se le acusa, igualmente, de lo contrario. Es decir, de falta de citas de autoridades en donde las circunstancias, a fe de los censores, lo hacían obligatorio, o cuando menos aconsejable. Pero es que además se le hace reo de o bien citar erróneamente o de inventar citas y testimonios inexistentes, tanto derivados de la doctrina y jurisprudencia como de las mismas leyes.

Finalmente no se considera adecuado su estilo y se aprecian algunas lagunas de escritura. Tal es el siguiente caso: «omite el autor la cita que señala la letra A, y al final del mismo número faltan palabras para hacer sentido». Su estilo es tachado de poco apropiado en diversas partes de su obra, principalmente se le acusa de generalidad, pero además, también, del uso indebido de expresiones como «más haya lugar en Derecho», etcétera ${ }^{25}$.

Sin quitar fuerza a estas correcciones de los comisarios, subyacen otras tachas más importantes que sin dejar de tener un cariz jurídico tienen una esencial y eminente naturaleza política o corporativa. Censura corporativa cuando Orejón critica los excesivos salarios y derechos que solían llevar los abogados. Y censura política cuando critica importantes instituciones, o más bien, los comportamientos de determinadas instituciones de la Monarquía o de la Iglesia.

En este sentido, don Antonio de Orejón acusa a la iglesia española de admitir siempre, por la excesiva bondad de sus ministros, en la inmunidad de sus casas y templos a cualquier tipo de criminales por muy execrables que fueran sus delitos, sustrayéndoles de esta manera de la jurisdicción regia, «porque comúnmente se llevan de un falso e indiscreto zelo de piedad los juezes eclesiásticos». Pero es que además, según Orejón, los ministros del Rey aceptaban esto al ser España una «nación extremadamente religiosa e imitadora del respeto y veneración de sus Reyes a la Yglesia».

Afirmaciones que los censores no admiten, pese a encontrarse en el siglo en donde las regalías se enfrentaron de forma más contundente a los derechos eclesiales y pontificios:

«Estimamos por ofensiva a los mismos jueces (eclesiásticos) estas expresiones, y tanto más dignas de haver devido omitirse quanto la experiencia nos acredita cada día que declaran en infinitos casos no gozar el reo del derecho de asilo, no obstante que en los tiempos en que escrivía el político Bovadilla, a quien el autor cita, sucediese lo que el mismo Bovadilla expresa»²6.

\footnotetext{
yes, bien que refiere las sabias providencias que se han tomado sobre el particular últimamente. $Y$ en quanto al estilo no tiene la maior exactitud y usa de algunas voces impropias como la de consuena en lugar de conforme. Es quanto la Academia puede informar, en cumplimiento de orden superior de Vuestra Majestad, que acordará lo que tuviere por conveniente. Madrid y marzo, 30 de 1784».

25 AHN, Consejos, Leg. 5551-3.

26 Ibídem. A veces podía resultar muy caro a personas y carreras el atreverse a criticar y solicitar reformas. La cita que en la nota 24 hacíamos de la censura de Guardiola y su Corregidor Perfecto y en es
} 
Pero no sólo fue la Iglesia víctima de críticas por parte de don Antonio de Orejón sino que, de la misma manera, los más altos estadíos de la Monarquía como lo eran el Consejo y la Cámara de Castilla, también sufrirían su análisis y sus propuestas de reforma. Por ejemplo para el autor resultaba inconcebible que los consejeros pudieran determinar los contenciosos que se les presentaban sin estar sujetos, ni atender, a las diligencias, sentencias, informaciones, etc., realizadas en instancias inferiores. Rompiendo así una natural cadena que partiendo de lo más cercano permitiese a lo más lejano al hecho, la Cámara y el Consejo, determinar sobre seguro. El ataque, aunque mesurado, a la práctica diaria de uno de los órganos más destacados de la Monarquía debía sin duda corrección, una censura que permite vislumbrar temor y servilismo, pero también el absolutismo que no admite la discrepancia en un simple práctico provinciano y menos que ésta se ponga por escrito. La respuesta censora a sus leves intentos de reforma procesal del más alto tribunal fue la siguiente:

«[...] Crehemos que no ha devido tocar esta questión, porque sobre ser bastantemente delicada, saben muy bien los señores ministros cómo se han de manejar para las decisiones. Y a los demás no nos incumbe tener ciencia de ello»27.

pecial la cuestión relativa al derrocamiento del rey que usase negligentemente de la justicia, pudo resultar el fin de la incipiente carrera política de su autor. Este, queriendo ocupar alguna vara de corregimiento, solicitó su examen, pero por entonces estaba su Corregidor en imprenta. Vistas sus teorías sobre los reyes negligentes, el gobernador de la Sala de Alcaldes de la Casa y Corte incoó una investigación reservada sobre las actitudes políticas del escritor jurista, de la que no resultó, en beneficio del interesado, un informe escabroso y sí, por el contrario, totalmente favorable. Tras ese fielato y comprobadas las bondades y descartadas las sospechas, Lorenzo Guardiola sería nombrado el 10 de septiembre de 1784 abogado de Pobres de los Tribunales Reales de Madrid. Iniciaba su carrera política aunque no todavía como corregidor. AHN, Consejos, Leg. 13382, pz.17.

27 AHN, Consejos, Leg. 5551-3. El caso de Orejón no es el único. Uno más, como ejemplo de esta cotidianeidad, el acontecido al licenciado Manuel Rodríguez Conde, vecino de Allariz en Galicia y abogado de la Real Chancillería de Valladolid, el que el el 1 de septiembre de 1785 solicitó ayuda y licencia para publicar su primer tomo de una obra titulada Astrea en su trono o España felizmente gobernada en la administración de Justicia. En la censura dada por el decano y miembros de la junta del Colegio de Abogados de la Corte, con fecha de 2 de mayo de 1786, se le dice que debe enmendarla si quiere que se publique pues: «Los dos puntos que toma el autor por objeto de sus discursos con que intenta persuadir por el primero lo conbeniente que sería desterrar de la universidades el Derecho romano y formar en ellas jurisperitos españoles y por el segundo la reintegración a la corona de los juzgados enajenados y probeerlos de letrados pueden mirarse con dos respectos harto diferentes: o como duda práctica propia del tiempo y de España o como una questión abstracta indiferente. Mirados en el primer concepto se fixa la vista en las providencias que por nuestros Soberanos y Vuestra Alteza, como supremo senado de la nación, hasta los más cercanos a nuestros días, cree el Colegio ser una materia la del primer discurso que la potestad pública la ha tenido siempre sobre sus primeras atenciones y que el no haberse dado ya un nuebo código español consistirá sin duda en que Vuestra Alteza, que vela incesantemente sobre todos los puntos interesantes de la causa pública y a la mayor ilustración, habrá conocido que tal vez no ha llegado este tiempo. Y por lo que hace al segundo discurso le juzga como una materia de Estado y reservada y que por lo mismo debe abstenerse de proponer su dictamen o censura en razón de si será más útil darle al público que conveniente el que esté reservado, y también porque sería dar lugar al fomento de escritores partidarios y con sus opiniones se intentase debilitar los derechos y regalías inherentes a la potestad pública del Soberano [...] La materia o asunto del segundo discurso es de la mayor consideración y mui propia para el ejercicio de la autoridad del Soberano sobre los personajes de quienes el autor habla y supone ser causa de los males que infieren a los pueblos, jueces y oficiales de república que eligen aquéllos, pero no para que se dé a la estampa y publique, por no ser justo dar con ello 
La censura y los censores -el doctor Antonio de las Peñas Vigo y Cortés y el licenciado Andrés de la Rica- que buscaron la depuración de la práctica en toda ella y desde luego la eliminación de puntos de crítica al poder, concluyeron del siguiente modo el 20 de diciembre de 1780:

«[...] Con atención a todos los explicados defectos, tanto más notables, quanto la obra por su título de Jurisprudencia Universal Theórica y Práctica devía ser de grande instrucción, adecuando a estas voces el contexto de ella lo que de ningún modo se verifica, aún quando fuera posible prescindirse de los mencionados defectos, nos parece que lejos de ser útil el darse a luz, será muy perjudicial a los jóvenes que se dediquen a su lectura» ${ }^{28}$.

Y así fue. La obra jamás vio la luz. El 29 de enero de 1788, la Sala de Gobierno, habiendo estudiado y visto la censura, Sala que estaba formada por los señores Velasco, Bendicho, Espinosa, Vallejo y Colón, digo que la Sala en esa fecha decidió la no publicación de la obra con un lacónico y final «escúsese».

\section{LOS APUNTAMIENTOS SOBRE LA HIDALGUÍA}

En 1788 los deseos de ver publicada su obra quedan rotos y no será hasta 1795 cuando don Antonio de Orejón consiga dar al público sus escritos. En relación con este último año, se puede afirmar que hacía ya tiempo que la Chancillería de Granada había dejado de ser objeto de la preocupación de escritores jurídicos de peso, cosa que salvo por los escritos de Juan Bautista Larrea y Elizondo y Álvarez nunca tuvo la suerte de soportar en demasía ${ }^{29}$.

Si esa era la tónica general, más lo era en cuanto a los procesos de hidalguía. En el siglo XVI y también, en parte, en el XVII e inicios del XVIII fueron tema de agitados debates en muchos y diversos ámbitos: estatales, municipales y particulares. Sobre todo en el siglo XVI. Tanto bajo Carlos I como bajo Felipe II las discusiones sobre estos pleitos y la preocupación por ellos fue relevante: ya por

ocasión a que se forme idea menos decorosa de la nación, por la que puedan imprimir los defectos de sus principales próceres», AHN, Consejos, Leg. 5550-62.

28 AHN, Consejos, Leg. 5551-3.

29 No obstante, hacen falta estudios, que nunca se han emprendido, para analizar hasta dónde hay que mantener lo aquí dicho, aunque ante la escasez de noticias, se puede aventurar casi con certeza que la Chancillería de Granada, frente a Valladolid, sufrió una pobreza mayor -cuantitativa y cualitativa- por lo que respecta a literatura jurídica y práctica que versase sobre ella. Últimamente se están revitalizando los estudios sobre la Chancillería de Granada y junto con los trabajos por ejemplo del director de su Archivo, David Torres Ibáñez o de la profesora Inés Gómez González, ya citada, destaca la edición del manuscrito de la práctica de la Chancillería granadina, muy útil para comprender las actuaciones del tribunal, José Antonio LÓPEZ NEVOT: Práctica de la Real Chancillería de Granada. Estudio preliminar y edición del manuscrito 309 de la Biblioteca Nacional de Madrid, Comares, Granada, 2005, y también sobresale el magnífico libro editado con motivo del centenario del traslado de la Chancillería a Granada con capítulos de Bartolomé Clavero, Carlos Garriga, Ignacio Henares, Miguel Ángel Ladero y Fernando Martínez, me refiero a Javier MOYA MORALES; Eduardo QUESADA DORADOR; y David TORRES IBÁÑEZ (eds.): Real Chancillería de Granada. V centenario 1505-2005, Junta de Andalucía, Sevilla, 2007. 
cómo debían llevarse, ya por qué remedio elegir para atemperar sus consecuencias sociales y políticas. De ahí que aparezcan en ese momento dos obras que se van a convertir en emblemáticas y las dos escritas por oficiales de justicia de la Real Chancillería de Valladolid y Granada: Arce de Otalora y Juan García de Saavedra.

El éxito de estas dos obras fue decisivo durante toda la modernidad e incluso después. Las obras están realizadas por dos servidores de la Corona y por dos hidalgos y cristianos viejos que son exponentes claros de la ideología más conservadora - sobre todo Otalora- y que, en consecuencia, son defensores de las más arraigadas y establecidas teorías nobiliarias, algunas no ajustadas a Derecho, lo que ellos mismos destacan cuando, a veces, exponiendo sus pensamientos reconocen que hubieron de actuar de otra forma en el ejercicio de sus oficios y esto con el único objeto de guardar las leyes.

En definitiva y contando con el francés Tiracquel, nombrado anteriormente, se debe reconocer que Otalora y García-Gallego o, lo que es lo mismo, García de Saavedra, se convirtieron en autoridades sobresalientes y fundamentales en materias tocantes a la nobleza española. Rara será la obra posterior en que no se nombre a alguno de ellos — seguramente más a Otalora - para fundamentar cualquier manifestación sobre estos temas.

Que Otalora, García de Saavedra y Tiracquel sean figuras señeras no impide que se puedan encontrar, en los siglos XVII y XVIII, otras obras de cierta calidad $-\mathrm{y}$ algunas exitosas - que aborden estos mismos temas y problemáticas, si bien también es cierto que en ellas la vertiente jurídica, estrictamente jurídica, suele ser tratada en menor cuantía y con menor calidad en favor de discursos que tienen un hondo contenido tradicional, a veces muy despegado de la realidad de su tiempo, y en los que se prima la exaltación de valores prototípicos de la nobleza. Sin olvidar que otros tratados, revisionistas y didácticos a la vez, contienen nuevos asuntos o, también, tratamientos nuevos para viejos problemas: la decadencia de la nobleza y de sus valores -siempre con respecto a los idílicos tiempos pasados-, los hidalgos pobres y vagos, la mala educación de todos ellos, su inactividad económica y social, etc. y, por último y sobre todo para el XVIII surge un tema realmente novedoso como lo sería la ampliación legal de la honra a determinadas dedicaciones profesionales en las que debía ocuparse la nobleza y, no sólo eso, sino ser ellas mismas causa de nobleza.

Para los siglos XVII y XVIII, desde la literatura estrictamente jurídica, no nobiliaria, el tratamiento que se da a la nobleza, si ocurre, suele encontrarse en ligeras puntualizaciones por ejemplo al describir, dentro de los sujetos de Derecho, las distintas clases de persona, $y$, también, al referirse a procesos y jurisdicciones, pero resulta obvio que no son el argumento central de las obras y de los autores. Lo dicho no impide la existencia de excepciones y así aunque sea en obras de naturaleza enciclopédica, como lo es la Práctica Universal Forense de Elizondo, se pue- 
den encontrar incluso a fines del siglo XVIII tratamientos más que dignos de la nobleza como institución jurídica ${ }^{30}$.

Elizondo no es un mero ejemplo. Francisco Antonio de Elizondo y Álvarez dedica numerosas páginas de alta calidad tanto a la nobleza como institución, como a la nobleza y su relación con el foro y el Derecho procesal. No en vano fue fiscal durante varios años en la Real Chancillería de Granada y como tal hubo de participar en todas las actuaciones que en esa Corte se vieron de hidalguía. Es sin duda, Elizondo con su Práctica Universal, quien pudo hacer de todo modo innecesario el trabajo de Orejón y Haro. Sin embargo Elizondo no llega a presentar un formulario completo de la práctica forense de hidalguía y ahí se encierra la oportunidad, fundamento y razón de ser de Los Apuntamientos de Orejón y Haro, pues como dice él mismo:

«[...] No se conoce algún compendio de fórmulas que contenga los recursos sumarios de hidalguía, los expedientes que corresponden a las demandas de propiedad, y la substanciación legítima de todos estos negocios: y como los pasos y movimientos peculiares de ellos difieran mucho de los que son comunes en los juicios civiles ordinarios, resultan muchas equivocaciones y tropiezos, aún entre los mismos que hacen profesión de la jurisprudencia, y una general ignorancia en todos los demás, por muy precioso que sea el fondo de su erudición. Y para que esto cese y qualquiera vea prácticamente cómo se entablan las pretensiones sobre el goce de la hidalguía y la dirección progresiva de cada uno de estos expedientes conforme a su naturaleza; me ha parecido poner en orden este formulario y agregar los apuntamientos que bastan a que cada uno entienda por sí mismo, qué diligencias deben executarse para que la Sala apruebe los recibimientos y condescienda a las continuaciones: tocando antes, aunque de paso, aquellos puntos que deben calificarse como conocimientos preliminares de la materia» ${ }^{31}$.

Por ello en la ciudad de Málaga, donde era también colegiado, el abogado don Antonio de Orejón publicará su obra en 1795 y será en la imprenta propiedad de don Luis de Carreras, impresor de la muy ilustre ciudad de Málaga, de su Dignidad Episcopal, de la Santa Iglesia Catedral y del Real Colegio de San Telmo, donde nazcan estos Apuntamientos sobre la Hidalguía y Colección de Fórmulas para todos los Recursos de esta Naturaleza. Con la instrucción que debe dirigir la de los extrangeros, conforme a la práctica que observa la Sala de los señores Alcaldes de los $\mathrm{Hi}$ josdalgo de la Real Chancillería de Granada. Obra útil para toda clase de personas.

Apuntamientos que a mi juicio deben mucho a su Jurisprudencia, nunca publicada, ya que es muy posible que sean, en cuanto a los formularios que aportan, parte individualizada del segundo tomo que tenía la Jurisprudencia, que como se mencionó era el destinado a una colección de fórmulas procesales. Es más, frente al aparato teórico, acertado o no, pero extenso, que tenía esta primera obra de Orejón, en sus Apuntamientos sobre la Hidalguía queda todo reducido a una bre-

30 Francisco Antonio de ELIZONDO Y ÁLVAREZ: Práctica Universal Forense de los Tribunales de España y de las Indias, 8 vols., Joaquín Ibarra impresor, Madrid, 1746- 1783.

31 Antonio de OREJÓN: Apuntamientos ..., pp. 5-6 
ve introducción de 27 páginas, muy general, sin entrar en grandes disquisiciones teóricas sobre la nobleza o sus procesos. Realmente a él le interesa la práctica, como práctico del Derecho que es, así que inmediatamente se introduce de lleno en las fórmulas, según él, siguiendo el estilo de la Real Chancillería de Granada, fórmulas que, como ya he dicho, posiblemente estuviesen recogidas en su inédita Jurisprudencia Universal.

De los Apuntamientos, sin duda y en primer lugar, destaca su muy largo nombre, a la usanza de la época, y destaca más aún ante las pocas páginas que contiene bajo tan extensa denominación: 142. Pero además cuartillas, no folios, con amplios márgenes y letra espaciosa y grande. En realidad una pequeña obrita pero no por ello poco densa, sobre todo en su segunda parte.

La obra publicada en 1795 -de la que no hubo nuevas ediciones- con el nombre de Apuntamientos sobre la Hidalguía y Colección de Fórmulas, especifica ya en su mismo título las dos partes claramente diferenciadas de las que se compone. Una teórica, los «Apuntamientos», breve, de no más de 27 páginas. $Y$ frente a ella una totalmente práctica basada en formularios y que realmente, como se aprecia al leer el libro, es la verdadera aportación que pretende hacer Antonio de Orejón y Haro.

Los Apuntamientos no buscan ser un tratado nobiliario, sino que siendo el todo una práctica procesal, se limitan a mostrar una serie de premisas de las cuales partir. Así está dividido este pequeño discurso en varios apartados que a continuación se reseñan:

- Hidalguía y sus especies

- Si puede el hijo ser hijodalgo siendo plebeyo su padre y al contrario

- Si los que traen origen de judíos o sarracenos pueden obtener la hidalguía, probando posesión conforme a la pragmática

- Si los extranjeros pueden ser hidalgos en España

- Oficios mecánicos. Cuáles sean y si se opone su ejercicio al goce de la hidalguía

Tal división, al igual que los asuntos tratados por Orejón en la parte teórica de su obra, estrictamente en los Apuntamientos, no son novedad alguna, pero cabe intuir, repito, que tampoco era éste el fin.

Ciertamente era necesaria la aproximación a la definición de hidalguía, pero sin decorados y barroquismos propios de los nobiliaristas y juristas del pasado y algunos de su presente y también de ahora, no hay que olvidar que se trata de un jurista muy apegado a la realidad. Por otro lado, aunque discusión no nueva, también es acorde con el tiempo en que escribe su preocupación por el ejercicio de oficios mecánicos y su compatibilidad con el goce de la nobleza. Discusión que ha brotado con fuerza entre todos sus coetáneos y que se va a ver amparada por leyes y por sentencias del alto tribunal, si bien Orejón no es muy partidario, aunque su pro- 
nunciamiento es tibio, a que se compatibilicen oficios mecánicos y nobleza. Lo que le aleja, como es evidente, de las teorías ilustradas de su época.

En cuanto a los otros tres restantes apartados son todos puntos que se repiten entre juristas y nobiliaristas siglo tras siglo, una vez ya realizadas las grandes aportaciones legales del XV-XVI sobre el desarrollo de este tipo de procesos.

En el texto, en el punto primero que versa sobre la definición de hidalguía y sus diferentes clases, Orejón se atiene a la típica, tópica, pero jurídica frase de Alfonso $\mathrm{X}$ por la que se dispone que «hidalguía es nobleza que viene a los hombres por linaje». No hay más, huye Orejón de circunloquios entre conceptos como nobleza espiritual o divina (los santos), la nobleza moral (los virtuosos) y la nobleza jurídica o política (los hidalgos), no le preocupa cuál es mejor o peor, ni las cualidades de cada una. A él sólo le importa la última que es la que se dirime de una u otra forma en los tribunales regios. Es más, llega a llenarla sucintamente de su contenido o por lo menos de sus efectos, pero desde el Derecho, no desde otro prisma. Dice así que es «una qualidad accidental que hace a la persona honrada y privilegiada sobre los plebeyos ${ }^{32}$. En cierto modo es casi una vanalidad decirlo, pero no se debe olvidar la parafernalia teórica que suele acompañar a los tratados sobre el tema y no sólo de nobiliaristas, sino igualmente de pensadores políticos y juristas. Obviada por Orejón, reconoce que la calidad nobiliaria es accidental, no debida a ningún tipo de origen moral, espiritual o divino.

Sólo es noble quien es reconocido por el Estado como tal y esa posibilidad de serlo radica en un puro accidente de nacimiento o, lo que es más, en la posibilidad -nunca segura para la gran mayoría- de demostrar tener derecho a tildarse de tal —de hidalgo - con el amparo del ordenamiento jurídico.

Desde su definición, apoyándose en crónicas - que no especifica-y en Partidas viene a intentar delimitar el origen de la nobleza española, de los hidalgos a los que retrotrae en su existencia aunque de manera no definitiva a la época de don Pelayo. En cualquier caso termina aseverando esa antigüedad y a la vez la imposibilidad de conocer su cierto principio, siguiendo a Arce de Otalora:

«[...] Así este nombre hidalgo, con que en España se distingue al noble de los demás, es tan antiguo en ella, que a la verdad no se descubre su principio»33.

\footnotetext{
32 Antonio de OREJÓN: Apuntamientos ..., p. 7

33 Antonio de OREJÓN: Apuntamientos ..., p. 10. Por otro lado de esta forma evita, igualmente, el entrar en una discusión, que ya viene de Las Partidas, consistente en distinguir al hidalgo del noble —entendido éste último como el que es hijo de padre y madre hidalgos_-, pues en la realidad resulta difícil de explicar por la práctica, por la común apelación de hidalgo utilizada por el pueblo para denominar al noble castellano, y por otra parte es difícil igualmente de aceptar en el fondo para toda la teoría nobiliaria hispana que el hidalgo no sea jurídicamente noble, cuando es hijo de noble y recibe la nobleza de su progenitor. Y por último sería desde todo punto inaceptable para los mismos hidalgos — todos se precian de su nobleza- y para la sociedad en donde existían y en la que jugaban un papel ciertamente importante. En definitiva es una huida de discusiones interminables que poco importaban para la realidad y para el jurista y menos al práctico.
} 
Por lo que atañe a los tres temas restantes, recordemos: Puede el hijo ser hijodalgo siendo plebeyo su padre y al contrario; Si los que traen origen de judíos o sarracenos pueden obtener la hidalguía, probando posesión conforme a la pragmática; Si los extranjeros pueden ser hidalgos en España. Digo, que estas cuestiones, que habían sufrido muy diversas contestaciones a lo largo del tiempo, son aquí resueltas sin hondas contemplaciones teóricas, aunque es obvio que Orejón las considera esenciales al traerlas a colación.

Sobre la cuestión de la ascendencia hebrea o musulmana y la nobleza, Orejón responde de diverso modo, pero siempre dentro de un no velado recelo. Para los últimos la admite con ciertas condiciones y reservas y para ello se acoge a Otalora, al igual que para el colectivo de ascendencia judía, pero en éste no hay duda, aquí es categórico: no pueden ser nobles por el crimen que cometieron con el Rey de Reyes. Lo cual no se ajustaba ni ajustó con la realidad ni con el Derecho castellano, pues muchos e importantes fueron los tornados cristianos que alcanzaron nobleza bien por medio de la verdadera gracia regia, bien por la adquisición de hidalguías, sin olvidar, claro, a los que consiguieron hacer olvidar sus pasados y se dieron por nobles.

En cuanto a los extranjeros, se aparta del muy conservador Otalora y considera a los nobles extranjeros perfectamente válidos para ser reconocidos por tales en España y gozar así de la posesión o la propiedad de la hidalguía, esta vez dándole la razón a García de Saavedra.

Nada más, el discurso teórico acaba, y con plena satisfacción expresa el motivo sincero de la publicación realizada al presentar la segunda parte: «[...] Basten ya los apuntamientos, y vamos a lo que es el objeto principal de este papel [...] (el formulario, la práctica)».

Orejón divide esta segunda parte a su vez en dos grandes grupos en virtud del carácter sumario o plenario de los juicios. El primer grupo estará compuesto por la solicitud de Estado, por la solicitud de la continuación de Estado, y en tercer lugar por una variante de ella por el recurso de continuación de Estado por comarca. El segundo grupo desarrolla por completo el juicio plenario, el verdadero de naturaleza contenciosa y que es el pleito de hidalguía por excelencia.

La obra en ésta, su segunda parte, está centrada, como formulario, en los ejemplos a modo de depuradas plantillas, en total 50 y no sólo de las partes sino también de actuaciones del tribunal, para que tanto el ejerciente como el profano puedan atender al desarrollo perfecto, eficaz y cronológico del pleito de hidalguía o de los recursos de hidalguía. 


\section{EL TRATAMIENTO PROCESAL DE LA HIDALGUÍA A FINES DEL ANTIGUO RÉGIMEN Y SUS PRECEDENTES HASTA EL AUTO ACORDADO DE FELIPE V DE 1703}

Cuando Orejón publica sus Apuntamientos, a fines del Antiguo Régimen, la hidalguía y, más aún, su tratamiento procesal había perdido la importancia jurídicopolítica que tuvo cuando menos hasta mediados del siglo XVII.

Muchas eran las voces contemporáneas a Orejón que ya clamaban, en base a la razón, contra la existencia de estos privilegios: Jovellanos, Cadalso, Fernández de Moratín, en la pintura Goya, etc., voces significadas que no dudaban en criticar y solicitar la anulación de estos privilegios, beneficios y exenciones en muchos casos fáctica y simbólicamente sostenidos por las ejecutorias, antiguas o modernas, expedidas por las Reales Chancillerías. Pero se estuviera de acuerdo o no con ellos lo cierto es que existían, persistían ${ }^{34}$.

En sus más oscuros orígenes la demostración procesal de la hidalguía no estuvo obligatoriamente ligada ex lege a causas económicas. Así, bien podía ser la causa metajurídica del comienzo de un litigio una cuestión de habladurías contra la nobleza de una determinada persona o familia, la oposición a que un individuo actuara como hidalgo o cualquier tipo de ofensa contra la situación jurídicamente noble de alguien, etc ${ }^{35}$. Si esto es cierto, no lo es menos que la vertiente económica del pleito de hidalguía se fue imponiendo en la práctica, siendo con frecuencia desde los siglos XIV y XV la única causa a través de la cual se solía llegar a entablar un litigio de esta naturaleza. Y, al fin, serían los Reyes Católicos gracias a su pragmática de Córdoba de 1492 los que definitivamente ex lege fijaran como única causa metajurídica que diera lugar a un verdadero pleito de hidalguía el prendimiento de bienes por negación a contribuir en pechos de pecheros o por la simple negación de contribuir en cualquier servicio ${ }^{36}$.

${ }^{34}$ AHN, Consejos, Leg. 5558, pz. 108. Esa existencia legal de la nobleza que tan inamovible y permanente en apariencia se mostraba, era para muchos en el siglo XVIII algo ya no imperecedero sino susceptible de desaparecer y estos pensamientos no eran sólo propios y exclusivos de los ilustrados más sobresalientes sino también de otras muchas gentes. La siguiente frase del ya citado modesto censor y clérigo Manuel Joaquín de Condado, escrita en 1792, refleja, hablando sobre la distinciones entre la educación de nobles y plebeyos, que para muchos estas distinciones eran ya no tan rotundas y que en cualquier momento terminarían por desaparecer: «Yo comprehendo que en quanto dure en una nación la diferencia de nobleza y estado llano o general, debe variar en ciertas cosas la educación de estas dos clases".

${ }^{35}$ La simple contradicción de la calidad personal sin más requisitos, está ya explicitada en nuestras antiguas leyes y ella es reconocida por causa metajurídica suficiente para dar lugar a pleito, así lo recoge por ejemplo el Fuero Viejo: «Esto es Fuero de Castiella: Que si algund ome contradijier que no es Fijodalgo, e aquél a quien contradice, dijier que lo es, dévese facer Fijodalgo con cinco testigos, los tres Fijosdalgo e los dos labradores, o con dos Fijosdalgo e tres labradores, sin jura. E este dicho que ellos dirán, dévelo oir el Fiel, que es dado de ambas las partes, estando amas las partes delante; E este Fiel debe tornar los dichos de los testigos al Alcalle, que judga el pleito, e para esto an nueve días de plaço», Fuero Viejo, 1, 5,18.

${ }^{36}$ Nueva Recopilación (en adelante $N R$ ) 2, 11, 8. «Y otrosí, porque no es fecha relación que muchos que se dizen estar en posesión de hijosdalgo y no son prendados por los Concejos donde viven, ganan de los dichos nuestros alcaldes de los Hijosdalgo y notario de la Provincia, nuestras cartas de emplaça- 
Lo dicho no quiere fundamentar que tan sólo por esta causa se discutiera procesalmente la hidalguía de alguien, sino que sólo por esa causa se podía entablar un proceso pleno de hidalguía. Incidentalmente existían procesos o acciones en los que se dirimía o se pretendía demostrar la condición de hidalgo o no, pero en ellos no era el centro del litigio esto sino otro derecho alegado por alguna de las partes. Me explico. Existían y existieron otros pleitos en donde se hacía aconsejable o necesario demostrar nobleza, por ejemplo en quiebras y deudas y éstas en relación con los bienes de un noble y los privilegios por él alegados, igualmente en contradicciones para gozar de la titularidad de un determinado oficio, en recibir penas infamantes, etc. Pero en ninguno de estos casos ni en otros similares, la cuestión de fondo era si se era noble o no, ya que en realidad lo que se discutía era si se podía gozar singularmente y para ese pleito del privilegio o fin exigido, como podía ser la inmunidad frente a los acreedores, ser alcalde por el Estado Noble o cualquier otro oficio que exigiera nobleza, etc., pues el fin deseado, la finalidad real de todas las actuaciones era ocupar ese cargo, ser inmune, etc., no el ser declarado noble. Es más, esto último sería indiferente si, en cada caso concreto, declarada y reconocida la hidalguía, por ejemplo no se le terminaba designando para el oficio deseado o no se respetaba en base a Derecho la alegada inmunidad que pretendía la parte al derivarse ésta de ser noble, etcétera ${ }^{37}$.

El pleito de hidalguía que en sí y desde la jurisdicción puede denominarse tal era aquél en donde el fondo del proceso no era otro que la determinación de la titularidad de la posesión o de la posesión y propiedad de la nobleza de una persona o de un conjunto de personas emparentadas -litisconsorcio- independientemente, primero, de la causa que lo originase y después con los Reyes Católicos, con una exclusiva causa metajurídica fundada en relaciones fiscales ${ }^{38}$.

miento contra los Concejos donde viven, y les hazen gastar sus dineros en seguimiento de los emplaçamientos, reçelándose que los harán pechar y hazen sus conciertos con los que goviernan los Concejos, para que no se siga el emplaçamiento y así han más ligeramente las sentencias de sus hidalguías. Por ende mandamos, que de aquí adelante los dichos alcaldes no den, ni libren cartas de emplaçamiento, ni escrivano alguno se las dé a librar contra ningún Conçejo sobre causa de hidalguía, sobre posesión ni propiedad, salvo si se le huviere ya prendado el Concejo por pechero al que se dize hijodalgo, y que ansí lo declaren en las cartas de enplaçamiento, y si de otra guisa se dieren que no valgan».

37 Existe una gran y diversa casuística, tanto cualitativa como cuantitativa, así y como ejemplo singular, el litigio que sufrió la hechicera y bruja de Jaén Leonor de Utrera, que aduciría su condición de hidalga, primero, para exculparse pues las artes mágicas no eran propias de nobles y cristianos viejos, y, en segundo lugar, para no recibir penas infamantes cuando fue condenada en Jaén y después en apelación por la Chancillería de Ciudad Real, véase Luis DÍAZ DE LA GUARDIA Y LÓPEZ: «La actividad jurisdiccional regia en primera y segunda instancia y la hechicería: Jaén y Ciudad Real en 1502", en Boletín del Instituto de Estudios Giennenses, 176-2 (2000), pp. 867-908. No obstante los aconteceres suelen ser más comunes, como cuando se buscaba la protección en cuestiones de deudas: así lo hizo en 1630, por ejemplo, el regidor perpetuo de Plasencia, don Francisco de Melo y Cabreros, cuando estando en la cárcel real por deudas, su procurador elevó un memorial al alcalde mayor que lo había aprisionado afirmando que «debe mandar soltar a mi parte de la prisión en que está, declarando a mi parte no poder estar preso por deuda ni por otra alguna que no desçienda de delito, por ser como es mi parte caballero hixodalgo de sangre», AHN, Consejos, Leg. 27837. No insistiré más en este aspecto pues aunque se sepa, carece de un trabajo concreto, pero sí está referenciado por la mayoría de los autores españoles que han tratado de la sociedad, el comercio o la nobleza castellana en la Edad Moderna.

38 Siendo por ley la única causa metajurídica para iniciar un pleito pleno de hidalguía la cuestión fiscal y como garantía exigida de ella la toma de prenda, en las ciudades y territorios en que o eran 
Cierto que para los no juristas la diferencia, en este caso, entre el fondo del litigio y su causa metajurídica resulta a veces difícil de discernir, no obstante es relevante y no sólo desde el punto de vista jurídico. Primero restringe de forma decisiva el amplio abanico que hasta entonces permitía el inicio de estos litigios y segundo se evidencia que para la Monarquía, para el Estado Moderno que nacía, necesitado siempre de recursos, la faceta más incómoda y por tanto más importante en su relación con la nobleza, no era otra que las pretendidas inmunidades tributarias de los hidalgos y también aquéllas relativas a los obligatorios servicios y cargas debidos a la Corona, de cuyo incumplimiento o negación se derivaba la toma de prenda, siendo valuables en dinero estos servicios y decantándose de ellos un perjuicio económico, no sólo político, para la Monarquía ${ }^{39}$.

exentos o todos contribuían la cuestión de salirse con su hidalguía en pleito resultó a veces muy difícil e incluso en el siglo XVI se tuvo que elevar a las Cortes de Valladolid de 1555 lo siguiente: «Petición CV. Otrosí, dezimos que muchos naturales de las montañas y de otras partes destos reynos tratan pleytos en las audiencias reales de Valladolid y Granada sobre sus hidalguías y so color de la pregmática hecha por los reyes cathólicos en la ciudad de Córdova o de otras leyes destos reynos, los oydores y alcaldes de los hijosdalgo de las dichas audiencias ponen duda en pronunciar por hijosdalgo a naturales de las dichas montañas y de otras partes, aunque prueban ser hijosdalgo de solar conocido, dando a entender que tal probança se ha de hacer con testigos pecheros, e que los que litigan sobre sus hidalguías han de probar haber bivido, o tenido bienes en lugares de pecheros, e haver estado en ellos en posesión de hijosdalgo ellos, e sus padres e abuelos, la qual probança e imposible de haçer muchos, aunque sean notorios hijosdalgo, e de solar conosçido por no haver bivido ni tenido bienes en lugares de pecheros. Y pues es notorio la nobleça antigua destos reynos tienen sus casas y solares conosçidos en cada parte, y es de creer que la intençión de los reyes que hicieron la dicha pregmática e leyes no fue obligar a los dichos hijosdalgo a provar cosa imposible ni quitarles su nobleza ni derecho, ni que lo proveydo para los hijosdalgo que viven en tierras de pecheros se estendiese a los vezinos de las dichas montañas e de otras partes destos reynos donde ay franqueza y libertad de no pechar porque sería indirectamente hazerlos pecheros. Suplicamos a V.M. por el remedio desto como cosa tan importante al real serviçio e bien universal destos reynos, y conservaçión de la nobleça antigua dellos: e que mande declarar e se declare por tales hijosdalgo de solar conocido a los naturales de las dichas montañas y de otras partes que han bivido en lugares libres y essentos de pechos aunque no lo prueven con testigos pecheros ni ayan bivido ni tenido bienes ellos, ni sus padres ni abuelos en lugares de pecheros: de manera que quedare por tales hijosdalgo de solar conoscido, ansí en possessión como en propiedad, sin los obligar a provar cosa imposible, ni que se les hagan sobre ello las dichas molestias y vexaciones. A esto vos respondemos, que se guarden las leyes y pregmáticas de nuestros reynos", Cortes de Castilla, Madrid, Congreso de los Diputados, 1903, p. 686.

${ }_{39}$ AHN, Consejos, Leg. 7046. Que no se trataba solamente de no servir en ningún repartimiento fiscal sino también en otros no menos importantes y que se mantienen durante casi toda la Edad Moderna, es muestra la siguiente consulta de 3 de febrero de 1581 motivada por las diferencias entre los pecheros y nobles de Casarrubio del Monte: «Pasqual Esteban y consortes, veçinos de Casarrubios del Monte, piden provisión para que cada y quando que a la dicha villa fueren soldados y hombres de armas a quien se ubiere de dar alojamiento y bagajes se haga el repartimiento entre todos los vecinos así hijosdalgo, familiares e ofiçiales del Ayuntamiento, como se haçe entre los demás pecheros. Porque quando a la dicha villa ban los dichos huéspedes e criados de Su Magestad se hesimen del repartimiento y de darles bagajes e alojamiento los hijosdalgo, familiares e ofiçiales del Ayuntamiento queriendo lo paguen todo los pecheros y pobres como se hiço en el mes de mayo pasado de 80 . Que yendo a la dicha villa la cavallería de Su Magestad, se hiço el repartimiento entre los veçinos pecheros quedándose fuera los hijosdalgo e familiares e ofiçiales del Ayuntamiento, lo qual no hera pecho, ni en servir a Su Magestad se avía de libertar ninguno. Presentan la comisión que se dio al alcalde de Tejada sobre lo de los carros, que manda que nadie se hesima de ella. Y también un mandamiento que dio el señor dotor Villafañé por abril de 79 a pedimiento de çiertos veçinos de la dicha villa para que el repartimiento que se avía de haçer en ella de las personas que avían de traher el pan a la Corte, que estava en Guadarrama, y de él no se esimiese sino que se hiciese entre todos los veçinos esentos y no esentos. Los hijosdalgo de Casarrubios por sí solos y no por los familiares ni otros salen a la causa y contradiçen la proviçión que piden los pe- 
Si estos son ejemplos que se pueden alegar para resaltar la importancia del establecimiento por los Reyes Católicos, como única causa metajurídica del pleito de hidalguía castellano, la cuestión fiscal, no lo es menos que este caso de Corte y su causa previa sea el único que según la tradición jurisdiccional castellana permite en un contencioso discernir la calidad noble o no de un individuo, pues esto y no otra cosa es el fondo que se discute y dirime en un pleito de hidalguía, no que se sea inmune, sino que por ser hidalgo se goza de esa inmunidad en esa circunstancia específica y en todas las demás que ocurran o pudiesen ocurrir y que además se goza de cualesquier otros privilegios y exenciones que corresponden a estos nobles en Castilla y su Corona, hayan tenido o no alguna relación con la causa metajurídica que dio pie al litigio, sin olvidar que en principio lo sentenciado es expresamente transmisible a sus herederos, siempre que en estos concurran determinadas exigencias jurídicas (legitimidad, línea de varón, etc. $)^{40}$.

Así mientras que en un expediente gubernativo concreto y accesorio a una cuestión principal, en el que se declare a una persona acreedora a cierta inmunidad, oficio o privilegio en base al reconocimiento de su hidalguía, lo que se pretende es utilizar la nobleza como instrumento a través del cual se establece la aptitud de una persona para un fin concreto en el que la nobleza es un puro accidente o requisito más o menos fundamental, mientras esto acontence de esta forma, por

cheros y diçen que es pecho llano y anejo de pagar ellos y no los hijosdalgo que jamás lo pagaron ni contribuyeron en semejantes repartimientos por ser esentos de ellos y aver estado en tal posesión y lo que piden es odio y enemistad que tienen a los hijosdalgo y que ellos están aparejados de yr a servir a Su Magestad en todas las ocasiones y se ofresçieron a probar. Los pecheros los contradiçen y piden se les dé la dicha provisión. Los hijosdalgo piden se deniegue y que ni la comisión de Tejada ni el mandamiento del señor doctor Villafañé no les para perjuiçio ni habla con ellos. Visto en Consejo se mandó poner a consulta y de ella salió decretado para otra y de la otra salió lo acordado. Agora los pecheros piden se declare qué quiere deçir lo acordado y tórnanse a querellar de nuebo de que quando se trujo el cuerpo de la reyna, nuestra señora, tanbién se les repartió huéspedes y se resistieron y no los quisieron resçivir. Presentan informaçión fecha por el alcalde de los Pecheros y de ella resulta que los hidalgos y otros requirieron que no se les hechase huéspedes y que dijo un Juan Gónçalez que si se le hechavan los resçiviría con un arcabuz y que en casa de un Françisco Bustamante no quisieron abrir la puerta y la derribaron para entrar. Visto en Consejo por los señores don Lope Rivadeneyra y don Fernando Mardones, se mandó poner en consulta. Después de esto presentan petiçión los hidalgos que se mandó juntar con lo demás, y por ella diçen que no resistieron los huéspedes quando el cuerpo de la reyna nuestra señora, que antes lo tubieron y regalaron e así se ha de haçer como tienen pedido. Ofresçen provar y contradiçen el castigo que piden los pecheros".

40 Se puede mantener que existían otras formas de demostrar nobleza y con mucha mayor honra que por medio de un pleito, en donde las partes se solían atacar con cierta crueldad. Es cierto, por ejemplo cuando un individuo pertenecía a una corporación nobiliaria y además exhibía su pertenencia a ella a través de hábitos, etc. Pero no se trataba de una vía contenciosa a través de la que hubiese demostrado su nobleza, ni siquiera cuando se ingresaba en una de las grandes Órdenes Militares. Es cierto que se realizaban instrucciones para demostrar y averiguar la legítima nobleza del individuo en cuestión y por lo general por sus cuatro ramas o costados, pero aunque podían intervenir fiscales que controlaban las gestiones y resultados, no existía un verdadero litigio, y, menos, cuando mayoritariamente el futuro cruzado ya había hecho las diligencias previas y usado de las influencias que tuviese para conseguir una recompensa política, al fin no era otra cosa, como era ser caballero de Santiago, Calatrava, etc. Pues, es más, en todas estas actuaciones la nobleza era requisito a cumplimentar no un fin, el fin no era otro que cruzarse y para ello, por lo usual, siempre habrá excepciones, su ingreso estaba más o menos preconcebido, establecido y consensuado por miembros, no necesariamente todos, de ahí los casos cruentos o cuestionados, de las Órdenes y de su Consejo. 
el contrario, en el llamado pleito de hidalguía pleno la excusa es el avasallamiento de una facultad y lo que es el verdadero objetivo es determinar la titularidad o no de la posesión o de la posesión y propiedad de la nobleza de una persona y en virtud de ello establecer la protección o no de la facultad presuntamente atacada y no sólo de ella, sino universalmente de todas las que pertenecen a los nobles de Castilla, facultades pero también obligaciones.

Causa metajurídica fiscal y naturaleza de caso de Corte, calidad que alcanza este litigio gracias a Juan I en 1379 (Era 1417), pues hasta entonces cualquier tribunal - verbi gratia los alcaldes de un concejo- podían entender y eran jueces naturales de estos pleitos ${ }^{41}$. Pero caso de Corte que hasta entrado el siglo XVI no fue de facto realmente un proceso reservado en exclusiva a las dos Cortes, Audiencias y Chancillerías de Valladolid y Granada, pues por un lado diversos privilegios medievales otorgados a determinados tribunales pugnaban con la ley antedicha y ejercían legítimamente su jurisdicción y, por otro lado, otros, por su propia voluntad y sin legitimación alguna, siguieron entendiendo de pleitos de hidalguía plenos, actuaciones estas últimas perseguidas por la Monarquía, anulables y mayoritariamente anuladas tanto en sí como en sus efectos mediante la intervención del Consejo y fundamentalmente de las Chancillerías. Pues la implantación de éstas y sobre todo el poderío y eficacia que toman con la Modernidad harán que sus mandatos y prohibiciones - existiendo siempre la excepción — fuesen acatados y cumplidos con mayor o menor prontitud, por lo que se puede aseverar que entrado el siglo XVI en adelante la naturaleza de caso de Corte reservado a las Chancillerías aunó lo legítimo con lo fáctico ${ }^{42}$.

41 Respuesta a la petición XIX de las Cortes de Burgos y que quedó recopilada como NR 2, 11, 12: «Ordenamos que el Fijodalgo que no fuere dado en nuestra Corte y Chancillería y con el procurador del lugar donde mora, y con nuestro procurador por Fijosdalgo, que la sentencia que por él fuera dada sea ninguna: y si después de dada la sentencia contra nuestro procurador, el Concejo del lugar donde viviere, opusiere no ser verdadero Fijodalgo, que lo debe de poner en nuestra Audiencia: y mandamos que sea oído y le sea administrada justicia, porque nuestros derechos sean guardados».

42 Un caso legítimo de esta contradicción de la ley regia a través del gozo de estos privilegios puede verse en la trascripción completa de una sentencia de 1435 dada en Murcia por un alcalde ordinario, en Luis DÍAZ DE LA GUARDIA Y LÓPEZ: «El deber de fidelidad al rey como justificación de hidalguía en la nobleza de España e Indias», en Anuario Mexicano de Historia del Derecho, XV (2003), pp. 103-168 (en concreto páginas 139-140). Sobre la persecución por parte de las Chancillerías al conocimiento de los pleitos plenos de hidalguía por concejos o otras instituciones también pueden verse ejemplos, entre otras obras, en mi artículo «Linajes nobles de Villarrubia de los Ojos del Guadiana en el siglo XVI y la Real Chancillería de Granada», en Cuadernos de Investigación Genealógica, Número extraordinario (1999), pp. 143-163. Sobre el caso de Corte en exclusiva reservado a las Chancillerías de Valladolid y Granada, no para las de Indias que no podían conocer del pleito pleno de hidalguía, me remito a mi artículo del Anuario Mexicano ... arriba citado, si bien quiero manifestar que ni en él se quiere defender, ni se indica en ningún modo, que las Audiencias y Chancillerías americanas y no sólo ellas — también otras instituciones coloniales - no pudieran entender incidentalmente sobre asuntos de hidalguía, cosa que sí ocurría y lo expreso, pues por vía gubernativa, sin contencioso, estaban facultados estos organismos para señalar estados y en concreto el de hidalgo y tampoco manifiesto en el referido artículo que siendo tan costosos y difíciles de realizar los pleitos plenos en la Península para todos los que residían en las coIonias, estas probanzas de nobleza expedidas por las instituciones coloniales, estos expedientes, no terminaran - rozando lo legal- sirviendo para demostrar nobleza no sólo para el caso en especial que los había motivado. Sobre este tipo de instrumentos y probanzas, véase Luis LIRA MONTT: «Provisiones ju- 
Los años finales del Medievo y los de casi íntegramente el siglo XVI, sobre todo en su primera mitad, son años de pleitos plenos de hidalguía para las Reales Chancillerías. La Corona, los mismos tribunales regios y el Consejo sopesarán la suspensión de los mismos o cuando menos los medios para evitar su inflación.

En esos tiempos no existen apenas instrumentos, documentos que atestigüen noblezas, salvo las grandes casas y algún que otro afortunado, la hidalguía se fundamenta en el comportamiento de su titular y de su familia y en la aceptación de ésta por la sociedad. Las filiaciones y su legitimidad, faltando en casi todas las iglesias libros registros de sacramentos hasta Trento, se demuestran únicamente por los hechos cotidianos y las memorias de las gentes, difícilmente retrotraibles a más allá de tres generaciones. Los padrones, en los lugares y momentos en donde se reservan o se tildan a los hidalgos, muchas veces se pierden por la mala custodia de los archivos municipales - custodia que vino a imponerse con mayor o menor fortuna por los Capítulos para Corregidores-, en definitiva para el $\mathrm{XV}$ y la primera mitad del siglo XVI, cuando menos, el fundamento de hecho de estos litigios quedaba y quedó mayoritariamente en manos de los testigos, en las probanzas hechas unas veces por receptores, otras por los alcaldes de los $\mathrm{Hi}$ josdalgos o los notarios de Provincia, y otras, incluso, por las justicias locales, por comisión y con poca supervisión de instancias superiores menos interesadas en la discusión ${ }^{43}$.

Sin olvidar, aunque sorprenda a muchos autores actuales que lo consideran erróneamente corruptela, que como es lógico y legítimo, hoy y ayer, las partes hacían testificar únicamente a los que podrían hablar en su favor y bien se guardaban, a través de los memoriales de tachas, de desvirtuar y descalificar a toda clase de testigos y testimonios que hablaran en su contra. Y digo partes, ambas, tanto las que querían salirse con la hidalguía como las que la contradecían. Pues en estos pleitos plenos de hidalguía, no sólo se discutían calidades y pasados, sino presentes y futuros. Eran cosa de importancia para las partes actoras, para las localidades y sus bandos, y, cómo no, para la Monarquía en general ${ }^{44}$.

diciales de amparo de noble dictadas por la Real Audiencia de Chile (1643-1807)", en Hidalguía: la revista de genealogía, nobleza y armas, 316-317 (2006), pp. 521-538.

${ }_{43}$ Esta preocupación y esta problemática ocupó a la Monarquía durante todo la Edad Moderna y no sólo a sus Chancillerías sino al Rey y al Consejo, tema ya tratado, aunque a veces minusvalorando la preocupación de la Monarquía, y tema que necesita igualmente de una monografía pero que no sólo alcance a los pleitos de hidalguía sino a todo tipo de probanzas. Ejemplos legislativos y consultas que se pueden alegar sobre esta preocupación son múltiples, tanto publicados o recopilados como inéditos. Sirva de muestra, una entre miles, la real provisión dada en Madrid el 2 abril de 1592 dirigida «Al presidente y oidores de la Chançillería de Granada para que en su acuerdo traten y confieran el remedio que puede aver para que no ayan fraudes en las provanças e ynformaçiones que se hazen por los reçeptores en cosas de ydalguías y enbíen razón al Consejo», AHN, Consejos, Lib. 640 E.

${ }^{44}$ AHN, Consejos, Leg. 7046. Que era importante y que no matemáticamente había connivencia de los concejos para hacer o reconocer por hidalgos a sus próceres, sino según los juegos políticos y las ambiciones del poder de cada momento, son muestra por ejemplo las numerosas consultas que solicitan no sólo ayuda económica sino reforzamiento de los componentes de los tribunales para asegurar la limpieza y corrección de los juicios plenos de hidalguía, valgan las dos siguientes. La consulta vista el 16 de junio de 1581 establece: "La villa de Belmonte dize que trata pleytos en Granada contra Pedro Delgado 
Las leyes como los Capítulos para Corregidores, la era que nace con la imprenta, Trento y sus registros sacramentales, la conservación de los documentos oficiales en archivos más o menos custodiados, la falibilidad —intencionada o no- del testimonio, la debilidad de lo oral frente a lo escrito que parece inamovible ante la historicidad, la proliferación de lo escrito tanto en la vida oficial como en ciertos sectores de la vida privada, en fin el nacimiento de una nueva época a la que no en poco contribuyó la actividad de las Chancillerías de Valladolid y Granada permitieron la existencia de un corpus documental nobiliario lo suficientemente abrumador como para que desde el último cuarto del siglo XVI en adelante, el fundamento de hecho reposara con solidez sobre lo escrito, frente a la probanza, frente a lo oral y memorístico, que sin dejar de existir hasta los fines de este tipo de litigios, fue sin duda perdiendo importancia en el seno de los procesos de los pleitos de hidalguía, y, en general, de los pleitos de naturaleza civil ${ }^{45}$.

De este modo los pleitos de hidalguía plenos y no sólo ellos sino también el resto de actuaciones de las que entendía la Sala de los Alcaldes de los Hijosdalgos, desde fines del XVI hasta el fin de la Edad Moderna, descansaron sus fundamentos de hecho esencialmente en lo escrito. Traslados de partidas de bautismo, matrimonio y defunción, copias de testamentos y de otras disposiciones notariales, copias o extractos de documentos oficiales de todo tipo, sobre todo - dada la obligatoria causa metajurídica - padrones de repartimientos - la moneda forera por excelencia al sur del Tajo- y cualesquier otros documentos que fueran pruebas indiciarias o plenas de filiaciones y nobleza, no de cualquier situación privilegiada, por ejemplo un privilegio de caballería o de excusado, etc., sino única y exclusivamente de la hidalguía y dentro de esto último, lo idóneo, acreditar

y el liçençiado Morales y consortes sobre su hidalguía y porque se reçela que no se berá con el cuydado que conbiene si el presidente de la dicha Audiençia no se alla presente a la vista de los dichos pleytos, suplica se le dé çédula para ello». La otra de 1 de diciembre de 1581: "Juan Gómez de Bedoya en nombre de la çiudad de Chinchilla sin presentar poder dize que el fiscal y el conçejo, su parte, tratan pleito en la Chançillería de Granada con Juan de Barrionuevo y Clemente de Barrionuevo y otros sus consortes, veçinos de la dicha çiudad, sobre su ydalguías y por ser pleito de muchas importançia y calidad pide se mande dar çédula real para que se vea por dos Salas». También es cierto que la Monarquía no era muy favorable a admitir estas peticiones, de concejos o de particulares, refrendado de este modo la actividad de sus Audiencias y sus jueces, y dejando para otros derroteros las medidas correccionales como la habida y conocida contra el fiscal Duque de Estrada o la de los alcaldes de los Hijosdalgos: doctor don Luis Mexía y el licenciado Ponce de León. Ambas medidas correctoras dadas en Valladolid en 1549, AHN, Consejos, Lib. 1414-E. Estas circunstancias y su abundante número, escasamente reflejadas por la historiografía pueden llevar a equilibrar la balanza que hasta ahora da a entender una corrupción generalizada en estos asuntos y una dejadez y desinterés por parte de la Monarquía.

${ }_{45}$ De ahí las probanzas ad perpetuam rei memoria, los expedientes que sin litigio se realizaban a petición de la parte hidalga para poner por escrito los hechos y nobleza de sus pasados, salvaguardados tan sólo en las memorias de sus convecinos y allegados, que de morir, llevarían al olvido su hidalguía y más concretamente acarrearían la desaparición de los únicos modos probatorios para casos de pleitos futuros de hidalguía o para cualquier otra circunstancia en donde hubiesen de alegar su nobleza. Era un buen método para salvar noblezas, pero también para ponerlas en peligro, pues debiendo el fiscal de la Chancillería supervisar las probanzas, podía y casi estaba obligado por la pragmática de Córdoba de 1492, podía, digo, denunciar la falsedad de la nobleza que se pretendía conservar y dar así inicio a un verdadero pleito pleno de hidalguía que en ningún modo era lo perseguido por quienes habían promovido la incoación del primigenio expediente. 
la conexión por línea recta de varón con un ascendiente que hubiese poseído ya una ejecutoria de alguna Corte declarándolo hidalgo, mejor aún si había sido expedida por la que en ese momento, nuevamente, discutía la nobleza de un linaje.

Muchos y habituales serán los pleitos plenos de hidalguía, en los siglos XVII, XVIII y XIX, que se ganen por los que se decían nobles al acompañar a filiaciones, probanzas y documentos, la acreditación de ser descendientes legítimos, por varón, de quienes fueron titulares siglos atrás de ejecutorias de hidalguía, me atrevería a decir que la mayoría y más aún conforme nos acercamos a los siglos XVIII y XIX.

Pero pese a que lo escrito, el documento, posea, para la actividad jurisdiccional y quizá también para cualquier otra, una mayor verosimilitud que lo testimonial, esto no es obstáculo para coincidir en que desde casi el nacimiento de la misma escritura nacieron con ella falsificadores y falsificaciones. Así pues en los pleitos de hidalguía, como en los motivados sobre vinculaciones de todo tipo y sus titularidades, en fin como en casi cualesquier otros, las falsificaciones abundaron. Unas fueron detectadas por los tribunales y otras se dieron por buenas. Cierto es que hay una presunción historiográfica a considerar casi todas las pruebas nobiliarias en especial en los pleitos de hidalguía y menos en los de vinculaciones, como fraudulentas. Pero no se puede ser tan absoluto ni apriorístico y menos aún se puede sugerir connivencias generales por parte de las Audiencias y Chancillerías que de la hidalguía entendían.

La Corona, desde siempre, y esto se evidencia en la legislación y en la documentación, fue consciente de que tanto los instrumentos como las probanzas eran susceptibles de mentir, de estar falsificadas o falseadas. En consecuencia intentó establecer cauces que aseguraran en la mejor manera posible la veracidad de lo aportado en los procesos.

Los cauces no fueron todo lo eficaces que se anhelaba y pretendía, esto es notorio, pero tampoco podemos por principio pensar mal de todo y en todo, haciendo común y general para todas las generaciones y administraciones pasadas la perfidia, la malicia, la corrupción, la ambición desmedida por el poder, en fin la falta de cualquier resquicio moral o ético, dando credibilidad sólo a aquellos testimonios teóricos o fácticos que denuncian o parecen evidenciar la escasa credibilidad de estos litigios y expedientes y menos aún se puede, por la historiografía, suponerlos fáciles fielatos para los aspirantes a que se les reconociera por nobles - la documentación, los procesos, sus probanzas, sus memoriales, sus costosas cargas económicas, etc.-, demuestran lo contrario de forma rotunda.

La debilidad fundamental de todo este entramado jurisdiccional y legal, reside, a mi juicio, en que pese a que se declaró caso de Corte, en que pese a que esto dejó de ser virtual para convertirse en real en la Edad Moderna, la Corona no pudo, no podía con sus medios, evitar que los fundamentos de hecho, las pruebas - que junto a los fundamentos de Derecho aportan por medio de la sentencia la realidad, 
la verdad jurisdiccional- digo que no pudo evitar que la mayoría de las fuentes probatorias escaparan al férreo control de los tribunales superiores, de la Corona misma que estos encarnaban.

Generalmente en los municipios, en los con frecuencia desordenados, mal custodiados y maltratados archivos concejiles -en esos arcones o armarios generalmente de tres llaves- se conservaba una gran proporción, por no decir la mayoría, de los instrumentos que atestiguaban, al sur del Tajo, la calidad jurídica de las personas: pecheros o hidalgos, por resumen, pues también constaban otros tipos de privilegiados, circunstanciales o definitivos, en origen normalmente de sangre cristianovieja y pechera.

Esta circunstancia debilitaba la fiabilidad de lo en ellos custodiado. Los municipios y sus concejos y cabildos de la Edad Moderna, como le es propio, eran instituciones con potestad tanto jurisdiccional como gubernativa, destinados a impartir justicia, por una u otra de esas vías. Pero en ellos y esto es muy conocido, y propio no sólo de la Edad Media y de la Modernidad, existía un factor muy influyente: el factor político, entendido, si se me permite, desde nuestra óptica actual.

Esa custodia y, también, esa fuente de creación municipal de instrumentos nobiliarios, unida a la vertiente política de los mismos concejos y cabildos propició definitivamente, en unos casos, las falsedades de difícil comprobación por autoridades superiores, y en su inmensa mayoría propició las sospechas y maledicencias generales.

Sobre los concejos y sus oficiales recaen, sin duda, las mayores sospechas pero no son los únicos, los escribanos y sus protocolos, las parroquias y sus registros sacramentales, todos ellos y su posible -más de una vez efectiva- manipulación y falsificación contribuyeron igualmente a propagar la sensación de poca seriedad de estos modos probatorios.

Pero no se debe olvidar que la manipulación -y la documentación lo avalano sólo jugaba en favor de los que querían ser tenidos por nobles sino que también jugaba en favor de sus oponentes y a éstos también se les acusaba e incluso condenaba por los tribunales, como reos de haber realizado tachas, borrones y cualquier artimaña que esparciese la sospecha y la duda sobre la verosimilitud de las pruebas de la parte hidalga. Al fin muchas cosas se jugaban: honras, ascensos 0 descensos sociales, envidias, odios, enemistades, etcétera. Por esto afirmaba don Antonio de Elizondo en 1783, entre lo cierto y también cierta exageración quizá:

«[...] La experiencia ha hecho ver, con dolor el más sensible, el grado de malicia a que han llegado los hombres en esta casta de negocios, donde abundan las falsedades de instrumentos de recibimientos, aún de los mismos libros capitulares, de actos positivos y la substracción de los legítimos. De modo que se presentan estos procesos en el territorio de nuestra Chancillería con tales coloridos que apenas pueden darse recibimientos y continuaciones comprensivos de tacha que merezcan ejecutoriarse. Cuyos desórdenes empeñaron mucho nuestro oficio para pedir a la Sala de Hijosdalgo una providencia general a fin de contenerles, la que con efecto 
se tomó, mandado: «remitan las justicias por la mano del fiscal testimonio del padrón de Hijosdalgos o negativo de no haberlo. Otro, de cuantos padrones para repartimientos de contribuciones, cargas concejiles, alojamientos, bagajes, alistamientos para milicias, quintas, sorteos y demás que en cada uno haya habido y actualmente haya, con expresión de los que se hubieren exceptuado o exceptúen los nobles o se les haya puesto o ponga la nota de tales. Especificándose el año de que es cada uno y de cuántas hojas se compone. Certificando no haber de los dichos ni otras clases. Y otro referente a los mismos documentos y a los libros capitulares de la distinción de estados que se ha observado y observa en cada uno de ellos, entre hijosdalgos y pecheros o absoluto de no haberla habido, ni haberla, ni otra de la que se certifique. Cuyos testimonios se pongan con asistencia de los ayuntamientos de cada uno de los dichos pueblos y concurrencia de los diputados del Común y síndico personero" (Carta circular impresa de 9 de febrero de 1782). Nosotros repetimos hoy, con la autoridad de uno de los grandes ministros de España (D. Amaya), que deben ser quemados, como reos de Lesa Majestad, los escribanos que den testimonios de inmunidades de tributos por favor, malicia o ambición. Lo que advertimos en este lugar, para que teniendo presente los señores ministros los muchos instrumentos falsos que se traen a estos juicios, impongan a sus autores, sin epiqueyas, el condigno castigo por un delito que al mismo tiempo incluye en sí muchas ofensas. Los recibimientos deben colocarse entre los papeles de esta clase y no de los de la otra, como hemos visto muchos en libros de apeos, repartimientos de haciendas y otros. Cuya sola circunstancia induce la presunción de falsedades (3 Larrea, alegato $96, n^{\circ} 29$ ). Notamos otros libros, donde se halla un pliego, que comprende un recibimiento con números duplicados y diferentes puntadas, que manifiestan haber estado anteriormente cosidos con otros papeles, cuyas circunstancias son motivo suficiente de falsedad. En algunos recibimientos observamos no tienen los números de sus folios similitud con otros iguales del libro en que se encuentran con una tinta antigua y diferente de la otra en que se extienden los demás documentos, siendo distinta la marca del papel y éste sucio, trasudado, con manchas y agujeros o puntadas, cuyos argumentos son nada equívocos de falsedad» 46 .

$Y$ es que el ser noble o no, mejor, el estar reconocido jurídicamente o no como tal, era en cualquier pequeña sociedad rural, también en las grandes localidades, pero quizá en éstas con menor impacto, un hecho de cualitativa importancia política en el territorio de la Real Chancillería de Ciudad Real y Granada, sobre todo en los siglos XV, XVI y XVII.

La historia política de nuestros concejos - poco estudiada en realidad, salvo desde el prisma del acaparamiento del poder por los bandos de poderosos u oligarcas- como es sabido fue en muchos casos y en muchos momentos si no violenta sí muy complicada. El poder económico, el poder jurisdiccional, el poder de decisión que influye en cada uno de los vecinos, la reputación social, etc., etc., etc., hacían, no siempre, pero sí en su mayoría muy apetecibles los oficios que componían cabildos y concejos, es algo sabido, pero al sur del Tajo, cuando menos, estos concejos en un principio estuvieron desde las sucesivas conquistas destinados, los medianos y más importantes, a los caballeros y, el resto, con excep-

${ }^{46}$ Francisco Antonio de ELIZONDO Y ÁLVAREZ: Práctica Universal ..., tomo III, pp. 212-214. 
ciones, a labradores pecheros. Si asimilamos caballeros con nobles, el resultado es que desde el principio de la reconquista del sur del Tajo, los municipios estuvieron en manos de nobles, pero esto no es asumible. La inmensa mayoría de los caballeros eran villanos, caballeros de premiá o alarde, frente a un menor número de los llamados caballeros de linaje (nobles). Caballeros de cuantía entonces privilegiados, pero de origen pechero y condición villana y recompensados, como también es sabido, por su actividad guerrera, con el poder local de cada una de sus villas y lugares. A fines del siglo XV, mayoritariamente, los concejos bajo lo que sería territorio de la Chancillería de Granada estaban pues en manos de concejos de caballeros villanos o de labradores pecheros, pocas localidades habían dado el paso que conducía a la nobleza al dominio absoluto de sus concejos y más bien los caballeros de linaje se insertaban en el sistema de cabildos de caballeros, pero por lo menos inicialmente con más abundancia de oficiales villanos ${ }^{47}$.

Es cierto que muchos de los de esta última categoría fincaron en concejos nobiliarios, por arrogación de la hidalguía por parte de los caballeros villanos, unas veces legalmente y otras subrepticiamente, unida, ésta, con su mezcolanza y asimilación con los caballeros de linaje de sus localidades, verdaderos hidalgos. Pero, pese a la generalización historiográfica de este patrón, no es menos evidente -la documentación lo señala - que en los siglos XV y XVI, en la zona de nuestro estudio, la tradición villana, connatural al medieval concejo castellano, estaba presente y muy arraigada ya fuese por vía del concejo de caballeros villanos, ya fuese por el de labradores pecheros. En esa coyuntura, y desde el último cuarto del siglo XV, pero fundamentalmente en el siglo XVI, durante todo ese siglo, se produce la petición primero y después el acceso al gobierno municipal por medio de la mitad de oficios de los estados de Hidalgos de esos lugares y villas que hasta entonces habían sido concejilmente pecheros. Quedando la mitad o parte de los oficios para los hidalgos y la otra para los caballeros de cuantía o los pecheros.

Esta búsqueda del poder local, que pretendía, cuando se pudiera, amoldar a los intereses políticos de los hidalgos las actuaciones municipales, no sólo dio lugar a una verdadera plaga de procesos, ante diversas jurisdicciones, para determinar las estructuras concejiles, sino que también produjo una verdadera inflación

47 La cuestión llegó reiteradamente a las Cortes de Castilla durante todo el siglo XVI — de una u otra manera- de este modo el capítulo XLII de las Cortes de Toledo de 1525 dice: «Otrosý, porque en algunos pueblos de estos reynos no consienten que los hijosdalgos entiendan en las cosas del pueblo, ni tengan alcaldías, ni alguacilazgos, ni regimientos, ni otros ofiçios, ni entren en sus ayuntamientos, suplicamos a Vuestra Magestad que, pues los hijosdalgo son de mejor condiçión que los pecheros, mande que sean admitidos en los dichos ofiçios syn que ninguna cosa lo ympida. A esto vos respondemos que mandaremos a los del nuestro Consejo hablar y platicar para que se provea lo que sea de justiçia», Cortes de los Antiguos reinos de León y Castilla, Real Academia de la Historia, Madrid, tomo IV, fol. 424. Para esta temática en general, aunque la historiografía nobiliaria y social ya se ha referido a esto en mayor o menor medida y desde diferentes perspectivas, me remito a mi tesis: Litigios de poder en concejos de la Real Chancillería de Granada: pecheros e hidalgos. La mitad de oficios en los siglos XV y XVI, (tesis doctoral inédita, dirigida por el catedrático Dr. Blas Casado Quintanilla), UNED, 2004. 
de procesos de hidalguía, pues en muchos de los pleitos de mitad de oficios no necesariamente casos de Corte y en ningún modo, cuando menos en Granada, competencia de la Sala de Hijosdalgo sino de la de lo Civil, las partes contrarias al establecimiento de esas nuevas estructuras municipales que conllevaban la pérdida o el reparto del poder solían exigir a sus oponentes, para reconocerlos partes legítimas en el litigio, la presentación de instrumentos - privilegios, provisiones, ejecutorias y a veces solamente admitían éstas últimas para no tacharlos como partes ilegítimas del proceso y por ende sin derecho a lo solicitado y exigido.

La introducción de la nobleza en el siglo XV y sobre todo en el XVI en los oficios concejiles fue sin duda un factor determinante en la producción del gran número de pleitos plenos de hidalguía que se llevaron por la Chancillería de Granada. No fue la única causa es evidente que para otros pleitos, sin más motivaciones, lo único que produjo su realización fue la toma de prendas por la negación a pagar impuestos o por el incumplimiento de cualesquier otros servicios, como alojamiento de soldados, bagajes, etc. Pero todo el conjunto produjo que la Sala de los Hijosdalgos y en apelación los oidores y el presidente tuvieran abundante trabajo en torno a la demostración de la calidad hidalga, abundante trabajo que desciende en el siglo XVII por dos causas: las guerras de Felipe IV y la existencia, ya comentada de abundante material escrito que acreditaba nobleza.

Las guerras de Felipe IV y la política nobiliaria del gobierno del conde-duque de Olivares retrotrajeron a la pequeña y mediana nobleza y esto pese a la ley que expresamente prohibió a los hidalgos abandonar su hidalguía y convertirse en pecheros, acto hasta entonces admitido y amparado por el Derecho tradicional y consuetudinario castellano. Pero en realidad muchos no acudieron a los llamamientos o consiguieron zafarse de los empadronamientos de corte militar, la mitad de oficios en muchos lugares decae, unas veces por la actividad de los pecheros, otras por la desaparición del Estado hidalgo. Sólo en los actos positivos económica o políticamente se permiten, y no todos, constar como nobles. En Granada y en su vega esto es evidente, pero también en Murcia, por ejemplo ${ }^{48}$.

$\mathrm{Y}$, al fin, decaen las celebraciones de litigios plenos de hidalguía porque existiendo tal cúmulo de material escrito —oficial u oficioso, legítimo o ilegítimo, verdadero o falso-, éste es utilizado por los hidalgos o por los que se dicen tales para que, presentándolo en las localidades de su vecindad, los concejos los recibieran por nobles dándoles tal estado. Cosa, ésta última, que también, siendo legítima, era favorable a los municipios y a sus munícipes que se intitulaban de la potestad de decidir quién era quién y a qué estado pertenecía, sin más instancia superior $y$, ya en litigio, que la Real Chancillería.

48 Lo señalé para Granada y su territorio en «Aburguesamiento de la nobleza ...». Para Murcia y de forma más detenida llegan a las mismas conclusiones Sebastián MOLINA PUCHE y Juan HERNÁNDEZ FRANCO: «El retraimiento militar de la nobleza castellana con motivo de la guerra franco-española (1635-1648): el ejemplo contrapuesto del reino de Murcia», en Cuadernos de Historia Moderna, 29 (2004), pp. 111-130. 
La abundancia de estas últimas actividades de recibimientos sin previo contencioso, su reiteración a fines del reinado de Felipe IV y durante el reinado de Carlos II motivaron que la Corona se decidiera a intervenir, pues con muy poca frecuencia estos actos eran supervisados por las Chancillería o incluso, a petición de parte, por el Consejo. Y será con Felipe $\mathrm{V}$ y en consonancia con la política de este Rey de reforzar el poder monárquico, cuando se promulgue un auto en 1703, que recogiendo en su seno una pragmática medieval de Enrique III, busque y lo consiga mayoritariamente, que los recibimientos sean supervisados por las Audiencias y Chancillerías, en este caso por la de Granada.

No hay litigio, pero puede dar lugar a él. En principio sin contencioso alguno se conjuga la actividad de la parte del que quiere ser dado por hidalgo, con la actividad del concejo que lo ha de recibir y ambas actividades son supervisadas al fin por el fiscal de la Chancillería que determinará, por un parecer, si hay duda o no en lo alegado, correspondiendo a los Alcaldes de los Hijosdalgo al fin dictar una real provisión en la que se mandase dar oficialmente el estado de hidalgo al peticionario. Claro está, siempre que no hubiese habido oposición por parte del concejo o por parte del fiscal, pues en ese caso la real provisión no facultaría al hidalgo a constar jurídicamente como tal y sólo le quedaría la vía del contencioso, previa prenda, para poder, ganándolo, ser admitido por noble.

Ésta fue la última gran aportación legislativa realmente eficaz que soportó o estructuró el pleito de hidalguía castellano hasta su desaparición. Y frente a la caída cuantitativa muy clara en el siglo XVIII y XIX para el pleito pleno de hidalguía, resulta igualmente nítido el auge de estas actividades de otorgamiento o recibimiento de estado por la Sala de los Hijosdalgos granadina ${ }^{49}$.

De ahí que buena parte del formulario de Orejón se decante por la explicación y la presentación de plantillas relativas a los recibimientos y otorgamientos o continuidades de estado de hidalgo a un vecino de cualquier localidad. Ése es posiblemente su mayor mérito pues se presenta así este libro como un formulario completo que al letrado y al litigante de entonces y al historiador de ahora, muestra el repertorio fundamental del tratamiento jurisdiccional de la hidalguía por la Sala de los Hijosdalgos de Granada para toda la Edad Moderna hasta el fin del Antiguo Régimen.

\section{CRITERIOS DE EDICIÓN}

Para la edición de esta obra de Antonio de Orejón y Haro, el que realmente, aunque de forma más depurada, supo plasmar el estilo de la Chancillería de Granada, como se ha dicho al inicio de este artículo, han sido utilizados los ejemplares

49 Destacar la labor aquí del conde de Borrajeiros, recientemente desaparecido, como gran estudioso de la legislación nobiliaria española, y señalar que fue, en la revista Hidalguía, si no el primero sí uno de los primeros en abordar los juicios sumarios de hidalguía de forma directa. 
custodiados en la Biblioteca Universitaria de Granada y en la Real Biblioteca de El Escorial.

En la edición se ha respetado estructura y ortografía original de la impresión de 1795 y tan sólo me he permitido, en ocasiones, puntuar o acentuar para una mejor inteligencia del discurso.

En cuanto al aparato de autoridades y citas y su forma, utilizado por Orejón, propio de la época en que editó este libro, igualmente ha sido respetado sin hacer en él corrección alguna.

\section{EDICIÓN}

\section{APUNTAMIENTOS SOBRE LA HIDALGUÍA Y COLECCIÓN DE FÓRMULAS PARA TODOS LOS RECURSOS DE ESTA NATURALEZA CON LA INSTRUCCIÓN QUE DEBE DIRIGIR LOS DE LOS EXTRANJEROS, CONFORME A LA PRÁCTICA QUE OBSERVA LA SALA DE LOS Sres. ALCALDES DE LOS HIJOSDALGO DE LA REAL CHANCILLERÍA DE GRANADA

\author{
OBRA ÚTIL PARA TODA CLASE DE PERSONAS
}

\section{PRIMERA PARTE \\ JUSTIFICACIÓN Y APUNTAMIENTOS SOBRE LA HIDALGUÍA}

El modo de dirigir prácticamente los recursos contenciosos de hidalguía es bastante obvio y sencillo; porque las reglas principales que versan en esta materia se encuentran explicadas con claridad en la pragmática de Córdoba ${ }^{50}$ de mil cuatrocientos noventa y dos y en el auto acordado ${ }^{51}$ de mil setecientos y tres.

Y aunque se ofrezcan, tal vez, dificultades y dudas, pueden fácilmente dirimirse con los escritos de D. Juan Arce de Otalora, Juan García, y Tiracuelo, que son los que más se han detenido sobre la nobleza de España.

Pero es de notar, que, sin embargo estos tres dejaron correr la pluma en cuestiones y puntos de pura especulación, son muy escasos los documentos que Otalora apuntó prácticamente, contentándose con extender las demandas del hidalgo contra el concejo, y de éste contra aquél; y los modelos de la contestación y de la sentencia definitiva en juicio ordinario. De modo que Juan García y Tiracuelo estuvieron remisos en esta parte, y ninguno habló del recibimiento al estado de los hijosdalgo, de la continuación en éste, y de aquellos otros recursos que suelen ser más frecuentes en las dos Chancillerías, únicos tribunales destinados por las leyes para el conocimiento de estos asuntos.

50 L.8, tit 11, lib. 2 Recop.

51 Aut. 5. eod. tit. 
No me olvido que el Sr. D. Francisco de Elizondo tocó algo en su Práctica Universal Forense, más no prosiguió, porque no conducía a su propósito. Y así no se conoce algún compendio de fórmulas que contenga los recursos sumarios de hidalguía, los expedientes que corresponden a las demandas de propiedad y a la substanciación legítima de todos estos negocios. Y como los pasos y movimientos peculiares de ellos difieran mucho de los que son comunes en los juicios civiles ordinarios, resultan equivocaciones y tropiezos aún entre los mismos que hacen profesión de la jurisprudencia, y una general ignorancia en todos los demás, por muy precioso que sea el fondo de su erudición.

Y para que esto cese y cualquiera vea prácticamente como se entablan las pretensiones sobre el goce de la hidalguía, y la dirección progresiva de cada uno de estos expedientes conforme a su naturaleza, me ha parecido poner en orden este formulario, y agregar los apuntamientos que bastan a que cada uno entienda por sí mismo, qué diligencias deben ejecutarse para que la Sala apruebe los recibimientos y condescienda a las continuaciones. Tocando antes, aunque de paso, en aquellos puntos que deben clarificarse como conocimientos preliminares de la materia.

\section{HIDALGUÍA Y SUS ESPECIES}

No es otra cosa la hidalguía que una cualidad accidental, que hace a la persona honrada y privilegiada sobre los plebeyos. Y según la ley de Partida ${ }^{52}$ «es nobleza que viene a los hombres por linaje». La cual es antiquísima, pues, omitiendo si la hubo en España antes de la irrupción general de los sarracenos, no es dudable que desde el principio de su restauración se hizo uso del nombre de hijosdalgo en los que quedaron con el infante D. Pelayo y le ayudaron en sus conquistas. Porque dicen las crónicas: «que entonces se juntaron con él los hijosdalgos».

En tiempo de Mauregato consta se pagaba a los moros en cada año el tributo de cien doncellas nobles e hidalgas, y otras tantas de baja suerte. En el reinado de Bermudo II, se lee: «hubo grandes disensiones entre los hidalgos y el conde de Castilla García Fernández, sobre los fueros y privilegios de sus hidalguías». Y más adelante floreciendo D. Borrel, cuarto conde de Barcelona, cuando fue menester llamar gente para defenderse de los moros, «se juntaron mil hombres de guerra bien aparejados, con los cuales se consiguió la victoria y, en galardón, el mismo conde armó caballeros a los que no eran hijosdalgos». Posteriormente, el Sr. D. Alonso el VIII «cargó a los hijosdalgos el pecho de cinco maravedíes, por consejo que le dio D. Diego López de Haro, a quien, porque redujese a efecto la imposición, ofreció en casamiento a su misma hermana». Y al darse la batalla de Alarcos hizo el Rey la expresión: «que tanto valía un villano como un hidalgo. Y entonces con trescientos de estos se retiró el D. Diego a un otero y no quiso pelear. Por lo que quedó el Rey vencido y él retado. Y habiendo respondido que mientras el Rey honrase a los hidalgos, sería honrado, volvió a la gracia de los hijosdalgos, con quienes estaba mal desde que dio el consejo para el tributo de los cinco maravedíes».

52 L.3, tít. 21, Part. 2. 
En las edades del Cid Rui Díaz, y del Sabio Rey D. Alonso nadie duda que hubo hidalgos, porque consta de muchas leyes de las Partidas. Así de este nombre hidalgo con que en España se distingue el noble de los demás, es tan antiguo en ella que a la verdad no se descubre su principio ${ }^{53}$.

\section{PUEDE EL HIJO SER HIDALGO SIENDO PLEBEYO EL PADRE, Y AL CONTRA- $R I O$}

De la hidalguía de privilegio no hay que dudar, pues si el príncipe concede éste al hijo, y no a su padre, aquél será hidalgo, y el otro quedará pechero. Cuando hablamos de la hidalguía de sangre repugna, al parecer, que el padre y el hijo sean personas de diversa condición y estado en la República. Pero si hemos de estar al pensamiento de D. Juan de Otalora ${ }^{54}$, debe hacerse distinción entre nobleza de sangre y la que se adquiere por cuasi posesión y prescripción conforme a la pragmática.

En la primera especie, causa dificultad creer, que estimándose al padre por hombre llano, pueda el hijo obtener ejecutoria de hidalguía. Más esto suele suceder en dos casos: uno, cuando el hijo, separando la persona de su padre, manifiesta título del abuelo, bisabuelo, u otros más antiguos ascendientes. Y el otro, cuando ese mismo hijo litiga y gana el recurso de su hidalguía, y después el padre provocando o siendo provocado a juicio sobre su nobleza, pierde la instancia y queda declarado por hombre llano contribuyente.

En la hidalguía de posesión o prescripción, puede muy bien acontecer que la Sala, al tiempo mismo que estime al padre por pechero, declare al hijo por hijodalgo, cuando demandados ambos juntamente, éste prueba su intención, y aquél no la ejecuta. Y esto mismo se verificará (considerando el caso contrario) siempre que el padre justifique la cuasi posesión de su hidalguía, y el hijo no pruebe suficientemente la suya. Pero si aquél litigó con separación y obtuvo la cosa juzgada, obra en favor de éste y le aprovecha. De manera que tendrá derecho a pedir sobrecarta de la ejecutoria despachada al padre e intentar con ella el recurso que le sea útil.

Entre hermanos, no hay quién dispute que al mismo tiempo que los unos gocen los privilegios y las exenciones de la hidalguía, sufran los otros las cargas y las contribuciones de los hombres llanos pecheros. Porque esto procede de mantenerse o no la cuasi posesión de hidalgos y ser o no tratados como nobles en los pueblos de las naturalezas y vecindades de cada uno.

\section{SI LOS QUE TRAEN ORIGEN DE JUDIOOS O SARRACENOS PUEDEN TENER LA HIDALGUÍA, PROBANDO POSESIÓN CONFORME A LA PRAGMÁTICA}

Muchas razones apunta Otalora ${ }^{55}$ en apoyo de que los que traen origen de judíos o sarracenos pueden, sin embargo, obtener los fueros de la hidalguía en España, como prueben los requisitos contenidos en la pragmática. Pero su dictamen es contrario y

53 Otalor. part.2, cap. 4, n.3.

54 Id. Otalor. cap. 8 secund. part. terc. princip.

55 Secund. part. terc. princip. cap. 7. 
añade que mientras que sirvió el empleo de fiscal en la Real Chancillería de Granada, hizo la observación que semejantes personas siempre perdieron los recursos que intentaron, no obstante que algunos produjeron una larga cuasi posesión de hidalguía y muchos indicios de antigua nobleza.

Lo cual, aunque en la opinión de algunos presenta un cierto aire de rigor, es ajustado a las leyes de la razón y la equidad, especialmente respecto a los descendientes de hebreos, porque a la verdad las cualidades de hidalgo y confeso pugnan entre sí de tal manera que no pueden reunirse en un propio sujeto y hacer buena comparsa.

Por otra parte, esta clase de personas tiene contra sí la presunción de no poder probar título apreciable de nobleza, puesto que sus autores fueron desde el principio infectos y muy opuestos a los Reyes de España. Por lo que no sólo se les expelió de estos dominios sino que se crearon contra ellos los Tribunales de la Fe.

A que se llega que el crimen de lesa majestad borra toda nobleza y dignidad y degrada de tal suerte al delincuente, que éste y sus hijos y descendientes quedan absolutamente excluidos de honores, oficios y distinciones de la república ${ }^{56}$. Y como el delito más execrable que el mundo ha visto, cometido en la Divina Persona de la Majestad de Majestades, Cristo Señor nuestro, es una nube espantosa que cubre a los recién convertidos y a sus padres. Ninguno de estos puede gozar en España los fueros y los privilegios de la hidalguía.

En orden a los que descienden de moros o sarracenos, aunque no sean susceptibles para estos los recursos de estado y continuación, pueden obtener en el juicio de la propiedad, como prueben una ascendencia limpia, noble y distinguida ${ }^{57}$. $Y$ así cita Otalora ${ }^{58}$ un cierto caso ejecutoriado en la Chancillería de Valladolid a favor de descendiente de sarracenos.

\section{SI LOS EXTRANJEROS PUEDEN SER HIDALGOS EN ESPAÑA}

Confiesa el mismo Otalora ${ }^{59}$ que a los extranjeros que residen en estos reinos, con motivo de la negociación y el comercio, favorecen graves fundamentos para que se les conceda el goce de la hidalguía. Aunque al propio tiempo, dice que en el tiempo que fue fiscal defendió siempre lo contrario, y deja al fin sin resolver esta cuestión, deduciendo varias conclusiones y permitiendo por la tercera de ellas, que en el juicio posesorio puede obtener el extranjero, más en la propiedad no lo concede, aún probando la inmemorial en toda su extensión.

Juan García ${ }^{60}$ discurre de otra manera, y sostiene que así en posesión como en propiedad pueden los extranjeros gozar en España los privilegios de la hidalguía, con tal que la hagan ver haber sido admitidos al uno de los oficios nobles acostumbrados a poner en personas de esta calidad y además justifiquen ser sujetos nobles, por nobleza

56 L. Quisquis. Cod. Ad Leg. Jul. Majest. signater \$. filiis. L. 2, tít. 2, Part. 7.

5 Garc. de nobilit. Glos. 7. subn. 19.

8 Otalor. loc. ult. cit. subn. 27. 19.

59 Cap. 5. Secund part.

60 De nobilit. Glos. 7. n. 18. 
heredada de sus mayores. Y así se practica.

\section{OFICIOS MECÁNICOS. CUALES SEAN Y SI SE OPONE SU EJERCICIO AL GOCE DE LA HIDALGUÍA}

San Isidoro, arzobispo de Sevilla, Ricardo y Hugo de San Víctor, con Aristóteles y otros de mucha antigüedad, dicen ${ }^{61}$ : que todas las artes mecánicas no exceden el número de siete.

Llaman a la primera Lanificio: la cual comprende cuanto puede conducir al adorno del cuerpo humano. $Y$ así se reducen a ella los ejercicios de tejer, bordar, coser, torcer y disponer todo lo que se hace con la mano y fabrica con la aguja, huso, telar u otros instrumentos en cualquier materia de lino, lana, seda y semejantes.

En las mujeres muchos de estos oficios son dignos de los elogios de los poetas, historiadores y filósofos, que pintan a las diosas, a las emperatrices y a las reinas, hilando, bordando, torciendo, cosiendo y tejiendo. $Y$ en los hombres aquellas mismas ocupaciones se estiman mecánicas, porque se ejercitan en ellas por pura flojedad, debiendo aplicarse a cosas más propias de su sexo y más útiles al Estado.

La segunda arte mecánica se dice Armadura, porque hacen instrumentos bélicos, unos para cubrir el cuerpo, como escudos, petos y viseras. $Y$ otros para defenderse, como lanzas, saetas, dardos y demás armas blancas y de fuego. Aquí se comprende también todo lo que es fundición u obra de martillo y lo que se fabrica con hachas, cepillos, escoplos y otros laboratorios en cualquier materia de barro, ladrillo, piedra, yeso, arena, cal y greda.

La tercera arte mecánica es la Navegación. Y ésta contiene en sí las ventas, compras, cambios y negociaciones. $Y$ de ella es miembro muy principal la marinería.

La cuarta es la Agricultura. Con sus cuatro extremos de arar y sembrar, apacentar ganados, plantar árboles y vides, y cultivar jardines y flores.

La quinta es la Venatoria. Reducida a cazar fieras y aves, y pescar en ríos y mares. Usando de redes, pértigas, lazos, arcos, tiros, perros, halcones, ligas, anzuelos y nasas.

La sexta es la Medicina. Que abraza todos los misterios necesarios para conservar la salud y para recuperar la que hizo atrasar la enfermedad, aplicando medicamentos por medio de operaciones, ya interiores ya exteriores.

Y la última es la Teatral. A la que pertenecen los juegos y espectáculos públicos de máscaras, versos, danzas, luchas, músicas y otras semejantes demostraciones de alegría.

Pero es de entender, que en esta materia obran eficazmente y sirven de regla la costumbre, la reputación y el concepto general, ayudado de la aceptación de los príncipes y magistrados. Así en Grecia fue muy autorizado el oficio de carpintero (que en España se ha tenido siempre por uno de los humildes y bajos) por cuya razón Homero ${ }^{62}$

61 Div. Isidor. lib. 15. Orig. cap. 2. usq. ad ro. Lib. 17. de reb. rust. Lib 18. de bello et ludis. Li. 19 de nav. edif. et lib. 20. de pen. inst. rustic. et domestic.

62 Lib. 23 de la Odisea.

63 Lib. 7. Var. histor. 
y Elidiano ${ }^{63}$ refieren que Ulises, famoso príncipe y capitán, fabricó naves e hizo camas por sus propias manos.

La ocupación de labrar el hierro, viene a ser igual en España a la de trabajar en la madera. Y entre los gentiles fue tenida por nobilísima, desde que se ejercitó en ella Vulcano, hijo de Júpiter y Juno. San Gregorio Nacianceno ${ }^{64}$ le pinta entre los carbones y oscuridad de las herrerías, como varón ilustrísimo y de suma importancia para lo más gloriosos de la milicia.

La mercadería, el trato y la negociación en tiendas públicas, aunque se haga por medio de cajeros o factores es incompatible con la distinción de los hábitos militares, según las leyes y estatutos de las órdenes. Y en Génova no impide el uso de las primeras honras y dignidades.

La Medicina, entre unos fue ocupación vilísima, testigos Tulio y Virgilio65, y entre otros se estimó como un ejercicio distinguido. Lo que dice Homero cuando habla de aquellos dos famosos príncipes, que fueron médicos, llamados Macaón y Chiraón.

El concepto que tienen en España los cómicos y farsantes a nadie se le oculta. $Y$ en los tiempos de San Agustín eran en Grecia personas ilustres y de suma nobleza y distinción ${ }^{66}$.

En orden a si el ejercicio de los oficios mecánicos se opone al goce de la hidalguía, deducirá con consecuencia el que se instruyere en las leyes del Derecho Común, y las observaciones de Otalora sobre este particular.

En Roma los pobres no eran reputados como nobles, aunque sus padres fuesen los más ilustres, porque la nobleza empezó (bien que no principalmente) por las riquezas, sin las cuales era difícil conservarla ${ }^{67}$. Por eso dijo Otalora ${ }^{68}$ que es en cierto modo injurioso a la hidalguía que gocen de ella los que no viven y se portan como nobles, sino envueltos en oficios y ministerios viles y bajos.

$Y$ en otra parte ${ }^{69}$, que en estos expedientes se deben atender principalmente las cualidades y circunstancias del litigante, las cuales mueven el ánimo judicial. Pues más fácilmente se inclinará éste a favor de aquél que de sí, su padre y su abuelo hace constar que todos fueron tratados en el concepto de nobles, que de aquél que, aunque pruebe su posesión de no haber pechado, no presenta otros indicios de hidalguía, especialmente si ha vivido en pueblos sospechosos y ha ejercido oficios mecánicos y contrarios al lustre de la nobleza.

64 Orat. 4. de Teolog.

65 Tul. in orat. pro Deyorat. Virgil. lib. 12. Encyd.

66 Div. August. lib. 2. de Civit. cap. 12.

67 L. 2. Cod. de prediis Decur. L. 45. Decur.

68 Cap. 7. Cuart. Part. princ. circa finem.

69 Cap. 6. Secund. Part. terc. princ. n. 15. 


\section{SEGUNDA PARTE \\ COLECCIÓN DE FÓRMULAS}

Basten ya los apuntamientos, y vamos a lo que es el objeto principal de este papel. De una de tres maneras puede el hidalgo litigar sobre su hidalguía y distinción. Una, pidiendo estado conforme a su calidad. Otra, pretendiendo la continuación en juicio sumario y breve. Y la última solicitando se le declare hidalgo y se le guarden las libertades y preeminencias que en su clase le corresponden, siguiendo una instancia ordinaria con el concejo.

\section{RECURSO PIDIENDO ESTADO}

En los concejos de las ciudades, villas y lugares de estos reinos es facultativo empadronar a sus vecinos y darles estado conforme a su calidad ${ }^{70}$. Hubo acerca de esto una cierta práctica en España que corrigió el auto acordado de treinta de enero de mil setecientos y tres ${ }^{71}$, ordenando: «que los ayuntamientos no hagan recibimientos de hijosdalgo de personas algunas, sin que preceda la justificación que se dispone por la ley del Dr. D. Enrique, que es la nueve del título once, libro segundo de la Recopilación. Con precisa obligación de dar cuenta dentro de un mes al fiscal de la Chancillería de lo que hubieren hecho, con apercibimiento de proceder contra ellos, y de que se les hará cargo en la residencia que se les tomare, así a los capitulares que se hallaren en dichos recibimientos como a los escribanos de su ayuntamiento. $Y$ de la justificación que precediere a cada uno de los dichos recibimientos, para que vista por el fiscal, siendo legítima y conforme a la ley, no pida cosa alguna. Y no lo siendo, pida se despache provisión con inserción de ella y se proceda conforme a derecho».

Esto supuesto, el pretendiente de estado en cualquier pueblo debe pedirlo como nuevo vecino o hacendado, porque si ha tenido vecindad por diez años, o si, aunque ésta no llegue a tanto tiempo se le ha tratado expresa o tácitamente como hidalgo o como plebeyo no puede intentar este recurso, sino usar de su derecho en juicio ordinario.

Puede acudirse, desde luego, al ayuntamiento y pedirse allí el señalamiento de estado, practicándose las diligencias con el arreglo que dice el auto acordado, y remitiéndose a su tiempo la compulsa a la Chancillería antes de dar la posesión de hidalgo, pero lo común es ocurrir éste derechamente a la Sala y pedir la provisión ordinaria. Y antes de extender el bordón del expediente que para ello se presenta, no deja de conducir por vía de claridad un árbol, que contenga la persona del pretendiente y las de su padre y abuelo.

70 L. 10, tít. 23, lib. 9. Recop. et concord.

71 Aut. 5, tít. 11, lib. 2. Recop. 


\title{
Expediente pidiendo la provisión de estado
}

\author{
M. P. S.
}

F. en nombre de D. Francisco Solís, vecino de la villa de Tarancón, ante V. A. en la forma que más haya lugar digo: Que mi parte es hijo legítimo, nacido de legítimo matrimonio de D. Joseph Solís y Doña Francisca Suárez, su mujer, y nieto con la misma legitimidad de D. Juan Solís y de Doña María Pérez, naturales y vecinos de la ciudad de Toledo, e hijosdalgos notorios de sangre. En cuya posesión de tales han estado y están de tiempo inmemorial, sin cosa en contrario, siendo exentos y libres de todos los gravámenes y contribuciones que sufren y toleran los hombres llanos pecheros. Y gozando y disfrutando cuantas honras, prerrogativas y distinciones corresponden a la nobleza de estos reinos. De manera que a vista de estas circunstancias ha estimado mi parte se le debe recibir al estado noble de cualquier pueblo de su establecimiento. Y para que así se verifique, en la ciudad de Antequera, a V. A. suplico se sirva mandar despachar a mi parte real provisión de estado en la forma ordinaria, por ser así de justicia, que pido, etc. y juro.

Para obtener este real despacho no hay necesidad de producir documento alguno. Con la relación que hace el interesado, la Sala manda expedirlo con inserción del auto acordado. Y aquí es de advertir que se ha de presentar dentro de treinta días contados desde el de la data. Porque pasado este término, no puede hacerse uso de él, ni el concejo debe darle cumplimiento sin nuevo mandamiento de la Chancillería.

El pedimento con que la real provisión se presenta al ayuntamiento es de esta manera.

\section{Pedimento para requerir al concejo con la provisión de estado}

D. Francisco Solís, vecino de la villa de Tarancón, ante V. en el modo que más haya lugar por derecho, digo. Soy hijo legítimo de D. Joseph Solís y Doña Francisca Suarez, su mujer, y nieto con igual legitimidad de D. Juan Solís y Doña María Pérez, naturales y vecinos de la ciudad de Toledo, e hijosdalgos notorios de sangre, en cuya posesión han estado y están, como yo, igualmente de tiempo inmemorial sin cosa en contrario, gozando y disfrutando de cuantas honras, distinciones y prerrogativas son correspondientes a la nobleza de estos reinos. $Y$ siendo libres y exentos de todos los gravámenes y tributos que sufren y toleran los hombres llanos pecheros. De manera que teniendo a la vista la opinión y fama y reputación y posesión vel quasi de la referida nuestra hidalguía, he conceptuado que se me deben guardar los fueros y privilegios de ella en cualquier pueblo de mi vecindad o establecimiento. Y para que así se verifique en esta ciudad con la autorizada solemnidad que corresponde, hice recurso a la Real Chancillería de la de Granada, y he obtenido la provisión que acompaña, con la cual, debidamente hablando, requiero a este ayuntamiento y le suplico se sirva, habiéndose por requerido, nombrar dos caballeros comisarios a quienes se haga saber el nombramiento, a efecto que precedido su juramento y aceptación, 
con su asistencia y la citación del caballero síndico de este Común, por el presente escribano mayor de cabildo se pongan los testimonios siguientes.

Uno de la distinción de estados que se ha observado y observa en esta ciudad. Otro del tiempo que soy tenido y reputado en ella por vecino. Otro del modo y forma con que se me ha tratado, expresándose clara y abiertamente que no he sido gravado con carga ni pecho alguno. $Y$ otro de la distancia que hay entre esta ciudad, Toledo y Tarancón. $Y$ mandar que a aquellos señores jueces y justicias se libren requisitorias, para que, quedando citado el caballero síndico de este Común, por hallarse distantes más de cinco leguas dichos pueblos, los escribanos de sus cabildos extiendan a su continuación los testimonios que se siguen. El primero de la distinción de estados que allí se ha observado y observa actualmente. El segundo de todos los actos positivos y distintivos de hidalguía que aparezcan a mi favor y el de mi padre y abuelo. Con la expresión que nunca estos ni yo hemos sido gravados con pecho ni carga concejil. Compulsándose así mismo las partidas de bautismo mío y de mi padre y abuelo y las de desposorios de estos, con los demás documentos de filiación e hidalguía, que por mi apoderado se señalen. $Y$ así todo evacuado y devuelto a este ayuntamiento, se me señale en su vista el estado noble que me corresponde, suspendiéndose darme posesión para el formal recibimiento, hasta que se apruebe por S. M. y señores alcaldes de los hijosdalgos de la Real Chancillería de Granada, a quienes se consulte con copia íntegra de los autos, por ser todo así de justicia, que pido, etc., y juro.

La serie de diligencias que deben ejecutarse, está bien descubierta en el relato del pedimento antecedente. El cual llevado con la provisión al cabildo, éste da cumplimiento, nombrando a dos de sus capitulares por comisarios con el poder y facultades competentes. De cuyo cargo es asistir a todo lo que se practica dentro del pueblo, y lo de la comarca, a donde deben pasar personalmente con la requisitoria o requisitorias que se despachen, quedando citado el síndico del lugar en que ha de ser recibido. Porque si las diligencias hubieren de hacerse en otros, fuera de las cinco leguas, los despachos requisitorios se entregan a la misma parte, para que los conduzca y devuelva, precediendo siempre la citación del síndico.

Igualmente es del cargo de los comisarios comprobar los instrumentos que se presenten e informarse de su certeza y de la posesión y estado que hubieren tenido el pretendiente, su padre y abuelo en los pueblos de su naturaleza y vecindades. Porque al fin han de poner por vía de informe todo lo que hubiesen advertido, para que al concejo sirva de regla y proceda con acierto a señalar el estado que correspondía.

Suelen estos comisarios, abusando de sus facultades, despachar por sí y a su nombre las requisitorias de diligencias, exhortando a las justicias de los pueblos donde han de practicarse, y usando un aire de jurisdicción que no tienen. Lo cual es opuesto a la misma letra de la provisión de estado, pues hablando ésta con el ayuntamiento dice «Vos el referido concejo despacharéis requisitorias con la dicha citación, para que en virtud de ellas se hagan en cada uno de los pueblos las tales diligencias", y así el mismo cuerpo del cabildo, como comisionado, es el que debe librar los despachos requisitorios que se necesiten. 
El ayuntamiento al requerírsele con la provisión, debe averiguar si el pretendiente ha tenido allí vecindad por diez años, o estado conocido, aunque de menos tiempo, o ya habérsele dado expresa o tácitamente o ya por haberse distinguido a su padre o a su abuelo como nobles o pecheros en los repartimientos, cargas o empleos en que haya sido costumbre hacer separación de las personas de uno y otro estado. $Y$ hallando que es así, no puede usar del real despacho, sino obedecerlo y hacerlo entregar al interesado para que ejercite su derecho como le convenga.

El caso de procederse a las diligencias se han de concluir éstas, en el todo, dentro de sesenta días siguientes al requerimiento de la real provisión. Y si resultan méritos para señalar el estado de los hijosdalgos, se remite a la Chancillería por mano del fiscal de S. M. de lo Civil un traslado o copia de los autos y del recibimiento, dentro de treinta días, sin darse la posesión hasta que éste se apruebe por la Sala, y en el ayuntamiento se presente el real despacho de la aprobación.

Los escribanos de cabildo de cada uno de los pueblos en que se practiquen diligencias deben saber que la Sala de Hijosdalgo tiene mandado que «precisamente certifiquen, además de los actos positivos que solicite el pretendiente, todo aquello que desde el principio haya ocurrido en favor o contra las personas de que se haga mérito, reconociendo para ello los libros capitulares, padrones, repartimientos, alistamientos para quintas y sorteos y demás papeles del archivo y escribanía, que al propósito sean conducentes, con apercibimiento que no ejecutándolo así, se evacuará a costa del que lo contrario hiciere, y que se procederá además contra él a lo que haya lugar».

En orden a los recibimientos de extranjeros, en otros tiempos se tenía por bastante la suplicatoria que por cualquier juez se despachaba a los tribunales de España, en virtud de una sola información de testigos, que declarasen la nobleza del pretendiente y su familia y refiriesen los empleos honoríficos que aquél, y las personas de ésta, habían obtenido. Pero hoy no basta esto. Ni la Chancillería aprecia las providencias que recaen sobre informaciones de testigos y exige como indispensable en estos recursos la prueba de instrumentos.

Por tanto el extranjero que intentare gozar de las exenciones y fueros de la hidalguía en España y obtener la provisión de estado para que se le reciba al de nobleza de aquel pueblo en que se establezca y fije su domicilio, si es inglés ha de ocurrir a los heraldos o reyes de armas. Si es italiano a los pretores. $Y$ así los demás a sus respectivos jueces o magistrados ordinarios, solicitando por sí o por medio de un apoderado, que constituya con sus poderes especiales, que en la forma que sea la práctica del país se le admitan las justificaciones las más solemnes de su ascendencia por línea recta de varón, hasta el grado que sea posible. Y que se compulsen (donde lo permita el Estado) las partidas de bautismos, desposorios, testamentos, escrituras de capitulaciones matrimoniales y otros documentos que justifiquen plenamente la genealogía. De modo que para el enlace de cada grado se verifique la referencia de padres, a lo menos, en dos de los instrumentos.

Debe también solicitar el pretendiente, que los escribanos de cabildo de los pueblos, así de su naturaleza, como de la de sus padres y abuelos (siendo diferentes) pongan los testimonios que se siguen: uno, que acredite la distinción que allí haya entre nobles y 
plebeyos. Otro, que pruebe los honores que haya gozado y lo que gozaron igualmente sus ascendientes por razón de su nobleza. Refiriéndose con toda claridad y explicación de los años y la cualidad de las prerrogativas que los unos y los otros obtuvieron. $Y$ otro que justifique que jamás fueron tratados ni reputados por hombres llanos.

En el caso que la familia tenga sepultura propia y uso de escudo de sus armas, se pasará a reconocer su situación. Se copiarán sus inscripciones o epitafios que se encuentren. Se delinearán las armas y se describirán los blasones, certificándose de todo esto en forma probante.

Además se practicará una información de testigos que declaren la residencia del pretendiente en España y la certeza de la filiación de éste por conocimiento y noticia que tengan de sus ascendientes, contestando la nobleza familiar y las distinciones y honras que han disfrutado. Extendiendo sus dichos los testigos no sólo a lo que resulte de los testimonios precedentes sino también a otras noticias que tengan a tiempos remotos. Y no omitiendo la expresión, de que por ser notoria la hidalguía de la familia los individuos de ella han contraído diferentes enlaces y casamientos con personas de esclarecido origen que refieran.

Para realce de estas justificaciones se indagará si era la capital a que corresponde el pueblo originario hay matrícula de linajes nobles, como en Génova el libro que llaman de Oro. Y habiéndola, y encontrándose allí anotada la familia del pretendiente, se pedirá y agregará a los autos un testimonio de lo que resulte.

Con estas diligencias el pretendiente pedirá su aprobación y que se le declare por hijodalgo de aquel reino y se despachen letras suplicatorias, con inserción de lo actuado, para que por los tribunales de España se le tenga y repute como tal y se le guarden los fueros de su nobleza.

Obtenido el despacho suplicatorio, debe éste presentarse al cónsul de España, que resida en el pueblo de origen o al que halle más inmediato, a fin de que lo reconozca, y tomando los informes que estime convenientes, certifique a continuación, que es cierto y verdadero su contenido, que intervinieron todas las solemnidades observadas en aquellos tribunales y que las justificaciones se hicieron con los mayores requisitos que se acostumbran para dispensar a los nobles las exenciones, poniendo el cónsul en esta certificación el sello propio de su empleo.

Este es el medio único de entablar los extranjeros sus recursos de hidalguía. Y todo lo que ejecuten de otra manera, será siempre inútil e infructuoso.

Remitidas a la Chancillería las diligencias, el fiscal de S. M. la ve y pone su dictamen, con el cual pasa todo al relator para que dé cuenta y estando en su poder, por parte del pretendiente se presenta un pedimento en que si darse por entendido del mérito de lo actuado, se solicita la aprobación del recibimiento en esta forma:

\section{Pedimento en la Sala pretendiendo se apruebe el recibimiento}

$$
\text { M. P. S. }
$$

F. en nombre de D. Francisco Solís, vecino de la villa de Tarancón, como más haya lugar, digo. Se han remitido a esta Corte las diligencias hechas sobre 
el recibimiento de mi parte en la ciudad de Antequera, y mediante que según resultará de ellas, aquél ha justificado su hidalguía y por lo tanto ha tenido el ayuntamiento fundado motivo para señalarle el estado de hijodalgo. Por tanto a V. A. suplico sea servido aprobarlo y mandar se le despache real provisión a efecto que el mismo ayuntamiento le guarde y haga guardar todas las preeminencias que como a tal hijodalgo le corresponden. Por proceder así de justicia, que pido, etc.

Si la Sala encuentra algún defecto sustancial en los autos, para mejor proveer manda se ponga el documento o se practique la diligencia que echó de menos y para esto se despacha provisión. Pero cuando halla corriente y sin reparo el recibimiento, lo aprueba desde luego en sus términos.

\section{Auto de la Sala aprobando el recibimiento}

Legágense [enlegájense] estos autos en la escribanía a que corresponden y despáchese a la parte de D. Francisco Solís, real provisión para que el concejo, justicia y regimiento de la ciudad de Antequera, en conformidad del recibimiento de hijodalgo que le tiene hecho le guarde y haga guardar todas las exenciones, franquezas y preeminencias que es estilo y costumbre en la referida ciudad y en estos reinos guardar a los hijosdalgos de sangre. Exceptuándole de todos los pechos y repartimientos de pecheros, y de las cargas concejiles, anotándole en la misma forma que a los demás hijosdalgo. Le nombre y proponga en los oficios de justicia correspondientes al estado noble, y no le impida ni embarace el uso del escudo y blasón de sus armas en las casas de su morada y demás partes que le convenga, a excepción de las iglesias de este reino de Granada, si no que para ello preceda licencia real. Todo sin perjuicio del Real Patrimonio en los juicios de posesión y propiedad. Y para que siempre conste, el citado concejo haga poner en su libro capitular un traslado de la expresada real provisión y ejecutado vuelva a esta parte la original, con testimonio de su cumplimiento, para guarda de su derecho. Proveído por los señores alcaldes del crimen y de hijosdalgo de la Audiencia y Chancillería de S. M., que lo vieron, mandaron y rubricaron en Granada, etc.

Con este real despacho se requiere al ayuntamiento por una petición que debe ser así:

\section{Pedimento para requerir al concejo con el real despacho de aprobación}

D. Francisco Solís, vecino de la villa de Tarancón, ante V.S. como más haya lugar, digo: que remitidos a la Real Chancillería los autos del recibimiento que esta Iltre. ciudad me hizo al estado de los hijosdalgos, se ha servido la Sala aprobarlo y despacharme la real provisión, con que (debidamente hablando) requiero a este ayuntamiento y le suplico, que en obedecimiento de ella mande cumplir y ejecutar cuanto contiene y que en virtud se me guarden todas las libertades, franquezas y exenciones que en estos reinos es costumbre guardar a los hijosdalgos de sangre. Libertándome de pechos, repartimiento y cargas concejiles. Nombrándome y proponiéndome en los oficios de justicia correspondientes al es- 
tado noble, y no impidiéndome el uso del escudo y blasón de mis armas en las casas de mi morada y demás partes que me convenga. Y para que siempre conste, se coloque en el libro capitular corriente un traslado de la real provisión, devolviéndoseme esta original con testimonio de su cumplimiento para guarda de mi derecho. Pues así procede de justicia, que pido, etc.

\section{RECURSOS DE CONTINUACIÓN}

Son estos unos juicios sumarios o unos interdictos muy semejantes a los de despojo. Y el uso de ellos compete al que hallándose en la posesión de hijodalgo, tenido y reputado como tal, se le grava con alguna carga real o personal correspondiente a los hombres buenos llanos contribuyentes.

Las diligencias que deben ejecutarse son iguales a las que se practican para los recibimientos, pues en las tres personas del pretendiente, padre y abuelo se han de justificar actos positivos apreciables de hidalguía. Se ha de probar la filiación con partidas de bautismos y desposorios y otros documentos que produzcan dos referencias de padre, a lo menos en cada grado. Y se ha de poner testimonio de la distinción de estados con citación del síndico y asistencia de comisarios en lo que se haga en el mismo pueblo o los que estén dentro de la comarca, y en virtud de requisitorias todo lo que se extienda en otros más dilatados.

Solamente versa la diferencia de que los autos obrados en estos expedientes no se compulsan ni se remiten oficio a la Chancillería, si no se entregan originales al interesado a fin que use en ella de su derecho.

El término para reclamar el agravio es sólo un año, pues si ha pasado más tiempo, se hace forzoso entablar la demanda en juicio ordinario, y ésta no tiene lugar cuando las pecherías exceden de veinte años.

El modo es acudir a la justicia el agraviado, relacionar su ascendencia y la posesión en que se halla de hijodalgo. Referir el caso que le ha despojado de ella, pedir se reponga la novedad y cese la causa de la inquietación, y con estas diligencias (si no consigue el intento) acude a la Chancillería, como explican los mismos expedientes.

\section{Expediente pidiendo la real provisión de continuación}

M. P. S.

F. en nombre de D, Antonio Joseph de Mendoza, vecino de la ciudad de Badajoz, como padre de D. Diego de Mendoza, ante V. A. en la forma que más haya lugar en derecho, me querello del concejo, justicia y regimiento de ella y digo: es mi parte hijo legítimo de D. Pedro Antonio de Mendoza y de Doña María Carrión. Nieto con igual legitimidad de D, Félix de Mendoza y de Doña Isidra Narváez. Y segundo nieto de D. Joseph de Mendoza y de Doña Catalina Páez, vecinos todos de la propia ciudad, donde en padrón ejecutado el año de mil seiscientos sesenta y seis, fue anotado el segundo abuelo de mi parte como hijo- 
dalgo: y también lo fueron con la misma nota los demás ascendientes de éste en sus respectivos tiempos, teniéndose a unos y otros, y reputándoseles por nobles, y sujetos de la primera distinción. Pues es así que ahora el capitán de milicias urbanas de la nominada ciudad de Badajoz, habiendo necesitado algunos reemplazos, incluyó en clase de soldado al hijo de mi parte: lo que reclamó éste ante el corregidor, por ser hidalgo, y haberlo sido sus padres y abuelos; en cuya inteligencia se mandó recoger el fusil que se le había dejado en las casas de su habitación, según todo resulta de los documentos que demuestro en debida forma, sacados con las solemnidades competentes: los cuales son prueba de la injuria que a mi parte, y su hijo se ha inferido; por tanto, y para su remedio: a V. A. pido, y suplico se sirva en vista de ellos mandar se despache a mi parte real provisión de continuación, a efecto que el concejo, justicia y regimiento de la citada ciudad de Badajoz, en conformidad de la posesión de hidalgos en que éste y sus ascendientes han estado quieta y pacíficamente: le continúe en ella, le haga guardar, y guarde todas las exenciones, franquezas y libertades; que según leyes de estos reinos, práctica y estilo de aquel pueblo se acostumbra guardar a los hijosdalgos notorios de sangre: no le incluya en carga alguna concejil: le proponga para los empleos propios de la nobleza: no le impida el uso del escudo y blasón de sus armas en sus portadas, y donde le convenga: y haga que para que en lo sucesivo conste se ponga en el libro capitular corriente una copia de la real provisión, devolviéndose la original a mi parte para guarda de su derecho, con testimonio de su cumplimiento por proceder así de justicia, que pido costas y etc. y juro.

Si la Sala advierte algún defecto, o nota algún reparo en los instrumentos que se le presentan, manda pasar el expediente al fiscal de S. M. y con la respuesta de éste toma providencia; pero cuando el recurso va corriente con una justificación clara, desde luego condesciende al despacho que se pide de la real provisión de continuación, por un auto que dice así.

\section{Auto de la Sala mandando despachar la real provisión de continuación}

Despáchese a esta parte la real provisión que solicita, para que el concejo, justicia y regimiento de la ciudad de Badajoz, continuándole el estado y posesión de hijosdalgo que en ella han tenido su padre y abuelos les guarde y haga guardar todas las exenciones, preeminencias y franquezas que es estilo y costumbre guardar a los demás hijosdalgos; anotándole en los padrones y repartimientos que hiciere con la nota correspondiente, y tratándole en todo como a los demás de su clase: y para que siempre coste, el referido concejo haga que en el referido libro capitular corriente se ponga una copia de dicha real provisión, devolviendo a ésta parte la original con testimonio de su cumplimiento, y de lo que en su virtud se obrare para guarda de su derecho. Proveído por los señores alcaldes del crimen, y de hijosdalgo de la Audiencia y Chancillería de S. M. que lo vieron, mandaron y rubricaron en Granada, etc.

Los pedimentos para requerir con estas provisiones deben formarse por el mismo estilo de los que se hacen para presentar las de aprobación de los recibimientos: 
siendo de prevenir que muchas veces los concejos por sí o por medio de algunos de sus capitulares van a la Chancillería, y contradicen el recurso del hidalgo, negando que éste lo sea, y pretendiendo no se expida el real despacho de continuación que pretende, o que se recoja, en el caso de haberse ya librado; cuya oposición corresponde ejecutarse de este modo.

\section{Pedimento de oposición del concejo al recurso de continuación}

$$
\text { M. P. S. }
$$

F. en nombre del concejo, justicia y regimiento de la ciudad de Badajoz, como más haya lugar en derecho, digo: tiene $\mathrm{V}$. A. noticia del recurso introducido en esta Corte por D. Antonio Joseph de Mendoza, de aquella vecindad, en calidad de padre de D. Diego de Mendoza, sobre la continuación de la hidalguía que supone, y de la real provisión que a este efecto le fue librada conforme al proveído de tal día. Y mediante a que la expuesta pretensión fue hecha con un relato incierto y contrario a la verdad; porque el D. Antonio, su padre y abuelo nunca han gozado la posesión de hijosdalgo, antes han sido, y son tenidos y reputados por hombres llanos pecheros, sin que se encuentre que alguno de ellos haya tenido otro carácter en el pueblo, ni haya sido recibido al estado de los nobles. En esta atención, y la de que los documentos que se presentaron no son solemnes, ni contienen méritos relativos a la ascendencia de $\mathrm{D}$. Antonio de Mendoza, y su hijo; pues los actos que se dicen positivos vienen a ser correspondientes a colaterales: por tanto y contradiciendo en forma la solicitud que aquél hizo para que se expidiese el real despacho de continuación: pido y suplico a V. A. se sirva mandar que éste se recoja, y no se use de él en manera alguna: declarando en caso necesario nulo, y de ningún efecto lo que en su virtud se haya ejecutado, y reservando al $D$. Antonio su derecho para que lo ejercite como le convenga; a cuyo fin (debidamente hablando, y sin que sea visto causar instancia) suplico del auto en que se andó despachar la real provisión de continuación, intento el recurso, y formo el expediente que sean más útiles en justicia, que pido costas, etc. y juro.

\section{Decreto}

Pase al fiscal de S. M. Granada, etc.

\section{Respuesta fiscal}

El fiscal de S. M. ha visto el recurso de D. Antonio Joseph de Mendoza pidiendo real provisión, para que el concejo, justicia y regimiento de la ciudad de Badajoz le continúe la posesión de hidalgo, que supone haber gozado con sus ascendientes; cuya pretensión contradice expresa y formalmente por su oficio, a causa de los documentos que D. Antonio produce, lejos de aprovecharle le perjudican.

Por tanto, suplica el fiscal de S. M. al Tribunal se sirva declarar por nulas todas las dichas diligencias, mandando despachar real provisión por su mano, 
para que el ayuntamiento de Badajoz trate, haya, y tenga por pechero a D. Antonio Joseph de Mendoza, y su hijo D. Diego, tildando y borrando las anotaciones, que como hidalgos se les hubiese puesto en los padrones y listas anteriores de orden de la justicia, o con cualquier motivo: o acordará sobre todo la Sala lo más conforme. Granada, etc.

\section{Auto mandando recoger la real provisión de continuación}

Recójase la real provisión de continuación librada a la parte de D. Antonio de Mendoza, el cual use de su derecho como le convenga: y despáchese al fiscal de S. M. la que dice, para que el ayuntamiento de Badajoz trate, haya y tenga como pechero al referido D.Antonio, y su hijo D. Diego de Mendoza, tildando y borrando las anotaciones que como a hijosdalgo se le hubiesen puesto en los padrones, y listas anteriores de orden a la justicia con cualquier motivo. Proveído por los señores alcaldes del crimen, y de hijosdalgo de la Audiencia, y Chancillería de S. M. que lo vieron y rubricaron. Granada, etc.

Esta providencia (como todas las de la Sala de Hijosdalgo) es apelable para la de los señores oidores: y si llevado a ella el recurso de apelación, no obstante se confirma, no queda al hidalgo otro remedio que hacer uso de la reserva, y entablar el juicio ordinario, sufriendo mientras las cargas, y pecherías correspondientes al estado general.

\section{RECURSOS DE CONTINUACIÓN POR COMARCA}

Hay otros recursos de continuación por comarca, cuyo ejercicio es propio de los que estando en la posesión de hijosdalgo en un pueblo, toman vecindad o hacienda en otro que esté situado dentro de las cinco leguas de distancia. Aquí no obra la inquietación ni el despojo, ni el expediente empieza por queja del ayuntamiento, ni tampoco se presentan papeles al principio: solamente se pone en la Sala un pedimento de esta suerte.

\section{Pedimento solicitando la provisión de diligencias en el recurso de continuación por comarca}

$$
\text { M. P. S. }
$$

F. en nombre de D. Francisco Velázquez, vecino de la ciudad de Loja, ante V. A. en la forma que más haya lugar, digo: Que mi parte es hijo legítimo en legítimo matrimonio de D. Miguel Velázquez, y nieto con igual legitimidad de D. Casimiro Velázquez, naturales y vecinos de ella, e hijosdalgos notorios de sangre, en cuya posesión de tales han estado, y están de tiempo inmemorial, sin cosa en contrario logrando y disfrutando cuantas honras, distinciones y prerrogativas corresponden a la nobleza de estos reinos, y siendo exentos y libres de todos los gravámenes y contribuciones que sufren y toleran los hombres buenos llanos pecheros: de modo que en tales circunstancias comprende mi parte le deben ser guardados sus fueros y privilegios en todos los pueblos donde se establezca, y a efecto que así se verifique en la villa de Villanueva de Mesía, en que 
es hacendado nuevamente por medio de una solemne continuación, respecto hallarse este pueblo dentro de la comarca: a V. A. suplico se sirva mandar se despache a mi parte real provisión compulsoria en la forma ordinaria: pido justicia, etc. y juro.

El requerimiento de este despacho se hace al ayuntamiento del lugar en que ha de ser la continuación. Allí se practican las primeras diligencias, se nombran comisarios, y estos pasan después a presenciar las que se ejecutan en el pueblo de la naturaleza y vecindad del pretendiente; más por cuanto el pedimento no es en él todo semejante al que se forma cuando se presenta el real despacho de diligencias para el recibimiento, se apunta aquí su modelo.

\section{Pedimento requiriendo con la provisión compulsoria}

D. Francisco Velázquez, vecino de la ciudad de Loja, como más haya lugar digo: Soy hijo legítimo de D. Miguel Velázquez y nieto de D. Casimiro Velázquez, naturales y vecinos de ella, e hijosdalgos notorios de sangre, en cuya posesión han estado y están de tiempo inmemorial, sin cosa en contrario, logrando y disfrutando cuantos honores, distinciones y prerrogativas corresponden a la nobleza de estos reinos, y siendo libres y exentos de todas las contribuciones y gravámenes que sufren y toleran los hombres buenos llanos pecheros: de suerte que comprendiendo yo debérseme guardar los fueros y privilegios que me competen en todos los pueblos de mi establecimiento para que así se verifique en esta villa, donde soy hacendado nuevamente, por medio de una solemne continuación, respecto hallarse dentro de la comarca, acudí a la Real Chancillería de Granada y he obtenido la real provisión compulsoria, con que (debidamente hablando) requiero a este ayuntamiento; y le suplico se sirva, habiéndose por requerido, nombrar dos caballeros comisarios a quienes se haga saber, a fin de que acepten el nombramiento, y que con su asistencia, y la citación del caballero síndico de este común, por el presente escribano de cabildo se pongan los testimonios siguientes: uno de la distinción de estados que se ha observado, y se observa en esta villa: otro de las escrituras que acreditan mi nueva vecindad, por razón de los arrendamientos que tengo hechos de diferentes tierras de labor en el término de ella: otro del tiempo que soy tenido y reputado como tal vecino: otro del modo y forma en que se me ha tratado, expresándose clara y abiertamente que no he sido gravado con carga ni pecho alguno: y otro de la distancia que hay desde esta villa a la ciudad de Loja; y mandar que los caballeros comisarios pasen a ella quedando citado el caballero síndico de este común, y con su asistencia se coloquen los testimonios que siguen: El primero de la distinción de estados que allí se ha observado y observa: el segundo de todos los actos positivos y distintivos de hidalguía que resulten a mi favor, y el de mi padre y abuelo, con la expresión de que nunca estos ni yo hemos sido gravados con pecho alguno, ni carga concejil: y el último de las partidas de mi bautismo, y los de mi padre y abuelo, y las de los respectivos desposorios de estos, con los demás documentos de filiación e hidalguía que por mí o por mi apoderado se señalen; y todo así ejecutado, se me entregue original para que en uso de mi derecho pueda instruir en la Sala el recurso que me sea más útil en justicia que pido, etc. 
Con estas diligencias en la Chancillería se entabla la pretensión formal, pidiendo la real provisión de continuación por comarca en los términos que siguen.

\section{Pedimento en la Sala pretendiendo la continuación por comarca}

M. P. S.

F. en nombre de D. Francisco Velázquez, vecino de la ciudad de Loja, hacendado en el término de la villa de Villanueva de Messsía, ante V. A. por el recurso que más haya lugar en derecho digo: Que mi parte es hijo legítimo en legítimo matrimonio de D. Miguel Velázquez y de Doña Eugenia Miranda, y nieto con la misma legitimidad de D. Casimiro Velázquez y de Doña María Suárez: los cuales, y todos los demás sus ascendientes fueron naturales y vecinos de la misma ciudad, e hijosdalgos notorios de sangre, en cuya posesión de tales han estado, y están de tiempo inmemorial, sin cosa en contrario, logrando y disfrutando cuantas honras, distinciones y prerrogativas corresponden a la nobleza de estos reinos, y siendo exentos y libres de todos los gravámenes y contribuciones que sufren y toleran los pecheros: de modo que todo esto ha servido a mi parte de fundamento para pensar que sus fueros y privilegios deben serla guardados en todos los pueblos de estos reinos: y para que así se verificase con la solemnidad que corresponde en la nominada villa de Villanueva de Mesía, donde se ha adquirido nuevamente hacienda, por medio de una continuación, a consecuencia de hallarse en la comarca de Loja, donde mi parte, y sus ascendientes han tenido y tienen la posesión de hijosdalgo, ocurrió aquel a esta Corte y obtuvo la real provisión compulsoria, que con las diligencias y justificaciones hechas en su virtud demuestro en debida forma. Y mediante a que de ellas aparece que mi parte en los varios sorteos que desde el año de mil setecientos setenta y seis hasta el de mil setecientos ochenta se echaron en Loja para reemplazos del regimiento provincial de milicias, y de los del ejército fue siempre excluido de entrar en suertes, por ser hijodalgo, poniéndosele la nota de tal en aquellas operaciones: que D. Miguel Velázquez su padre, habiendo acudido a la justicia de la propia ciudad, y hecho de ver su calidad y nobleza, consiguió providencia en el año pasado de mil setecientos treinta y ocho, para que se notificase al número de escribanos, y a las demás personas que correspondiese, le continuaran guardando las exenciones que le pertenecían como a caballero hijodalgo: lo cual así se ejecutó, y los autos quedaron protocolados para que siempre constase, y de ellos se diesen las copias que se pidieran: que D. Casimiro Velázquez su abuelo en pleito que siguió en la Audiencia Episcopal de Málaga con el fiscal general de ella, ejecutó la posesión de la capilla, patronato y sepultura que gozaba en la iglesia parroquial de la villa de Mijas, como descendiente de las nobilísimas familias de Velázquez, Gómez y Sepúlveda, que desde Fernán Núñez, reino de Córdoba, vinieron a la reconquista y expulsión de los moriscos de aquel pueblo, y quedaron en él para su población con suertes que le fueron repartidas en señal de su distinción; y que todos los demás ascendientes de mi parte, hasta su séptimo abuelo, fueron siempre tenidos y reputados como hijosdalgos notorios de sangre en los diferentes casos que aparecen de las diligencias que quedan 
demostradas: por tanto a V. A. suplico se sirva en vista de ellas, y en conformidad de la posesión de hijosdalgo que mi parte y sus ascendientes han tenido en la ciudad de Loja y villa de Mijas, mandar se le despache real provisión, para que el concejo, justicia y regimiento de la villa de Villanueva le haga guardar y guarde todas las exenciones, franquezas y libertades que según leyes de estos reinos, práctica y estilo de la misma villa se acostumbran guardar a los hijosdalgos notorios de sangre: no le incluya en carga alguna concejil: le anote como hijodalgo en los padrones que haga del vecindario: le proponga para los empleos propios de la nobleza, habiendo mitad de oficios: no le impida el uso del escudo y blasón de sus armas en las portadas de sus casas, capillas, enterramientos, alhajas de oro y plata y demás partes que tenga por conveniente: y haga que para que así conste en lo sucesivo se ponga en el libro capitular corriente una copia de la real provisión, y se devuelva a mi parte original con testimonio de su cumplimiento en guarda de su derecho, pues procede todo de justicia que pido, etc. y juro.

La providencia de la Sala que condesciende al despacho de la real provisión de continuación por comarca, es igual a la que manda expedir la de las otras continuaciones: y sólo tiene de especial una cláusula en que se dice: que si el interesado quiere recoger los papeles que presentó como fundamento del recurso se le entreguen, quedando una copia de ellos en el expediente: y el pedimento para requerir al ayuntamiento se hace con la misma relación de los que se forman en los otros requerimientos.

Algunas veces el hidalgo suele encontrar anulación en el concejo, y por esta causa no conseguir el cumplimiento llano de la provisión de continuación; en cuyo caso el remedio es acudir a la Sala y pedir la sobrecarta de ella, con demostración de la original y diligencias de su obedecimiento, porque si éstas no se presentan el nuevo real despacho deberá ser lo proveído.

\section{Expediente pidiendo la sobrecarta}

\section{P. S.}

F. en nombre de D. Francisco Velázquez, vecino de la ciudad de Loja, hacendado en el término de la villa de Villanueva de Messía, como mejor proceda de derecho me querello del concejo, justicia y regimiento de ella y digo: Tiene $\mathrm{V}$. A. noticia del recurso de continuación entablado por mi parte en esta Corte, y de la real provisión que le fue despachada, para que el mismo concejo continuándole en el estado y posesión de hijodalgo que su padre y abuelo habían tenido, le guardase e hiciese guardar todas las exenciones y preeminencias que son propias de los demás hijosdalgos, anotándole en los repartimientos y padrones con la nota correspondiente, y tratándole en todo como a los demás de su clase. Pues es así que habiéndose requerido con el real despacho al referido concejo, pretextando éste motivos que no hay, lo obedeció, pero no lo ha puesto en ejecución, según resulta de la real provisión original, que en debida forma demuestro con las diligencias extendidas en su razón. $Y$ mediante a que la respuesta del concejo es maliciosa, e infundada, sin otro objeto que la vejación y 
molestia de mi parte por ideas y fines particulares que no deben disimularse; por tanto y a efecto que todo se remedie a $\mathrm{V}$. A. pido y suplico se sirva en vista de la real provisión original y diligencias que quedan demostradas mandar se despache a mi parte la sobrecarta de ella, para que convocados a cabildo los capitulares que componen el ayuntamiento de Villanueva de Messía, le pongan llanamente su cumplimiento, y ejecuten todo cuanto contiene, y después de practicado si tuviesen algo que decir, lo hagan en juicio correspondiente: para todo lo cual se impongan las multas y apercibimientos que parezcan más convenientes en justicia, que pido costas, etc. y juro.

\section{JUICIO PLENARIO}

Por lo que queda expuesto en los juicios sumarios que anteceden, es fácil comprender cuando el que pretende la hidalguía debe por necesidad seguir un juicio ordinario con el concejo y el fiscal de S. M. partes formales, sin cuya intervención sería nulo cuanto se obrase.

Otras veces el mismo concejo es el que promueve la instancia contra el hidalgo: y en uno y otro caso éste solicita se le declare por tal y se condene a aquel a que le guarde las exenciones y libertades que le corresponden y le tilde y borre de los padrones en que le tenga anotado en clase de pechero: y el concejo pretende que el que se titula hidalgo sea declarado por hombre llano pechero, y se le condene a que peche y contribuya, sirva y ejerza los oficios y cargas que son propios de los demás hombres llanos pecheros.

Por un otrosí de estas demandas de los concejos siempre se pide y se manda por la Sala despachar provisión con inserción de la ley del Sr. D. Enrique, (A) para que mientras el pleito se sustancia, peche y contribuya el demandado a cuyo nombre se forma comúnmente artículo sobre que se recoja, y no haga uso del real despacho, alegando para ello estar a su favor alguna de las limitaciones que la misma ley señala.

En lo demás, los pasos y movimientos de los juicios plenarios de hidalguía vienen a ser iguales a los que se practican en los otros negocios civiles ordinarios con alguna muy rara diferencia, según se ve en el giro y sustanciación que sigue de la demanda del concejo contra el hidalgo: colocándose antes, para que nada se eche de menos, la que es propia de éste cuando intenta litigar con el cuerpo del ayuntamiento.

\section{Demanda del hidalgo contra el concejo}

$$
\text { M. P. S. }
$$

F. en nombre de D. Francisco de León y Luna, vecino de la villa de Manzanares, ante V. A. como mejor proceda de derecho, demando al concejo, justicia y regimiento de ella, y al vuestro fiscal en esta Corte y digo: Que siendo como es mi parte hijodalgo notorio de casa y solar conocido, y devengar quinientos sueldos, según fuero de España: y habiendo juntamente con su padre, abuelo y demás ascendientes en la posesión de tales, así en aquella villa como en los 
otros pueblos donde han vivido y morado, tenido y poseído bienes y hacienda de diez, veinte, treinta, cuarenta y cincuenta años, y de tanto tiempo que no hay memoria de hombres en contrario, no pechando ni contribuyendo con pechos algunos reales, o concejiles con que pechan y contribuyen los hombres llanos pecheros; antes guardándoseles todas las honras, franquezas, exenciones y libertades que se guardan y deben guardar a los hijosdalgos notorios de solar conocido, juntándose con ellos en su ayuntamiento y yendo a las guerras y llamamientos que en diversas ocasiones se han mandado hacer a los hijosdalgos de sangre: ahora de algún tiempo a esta parte, contraviniéndose a la hidalguía y posesión que la mía, su padre, abuelo y ascendientes han gozado quieta y pacíficamente, el referido concejo ha empadronado a mi parte y le ha sacado prendas por pecho de pecheros, según lo justifica el testimonio que en debida forma demuestro; y aunque esta novedad fue reclamada inmediatamente con la solicitud de que las tales prendas se devolviesen, y se borrase a mi parte de los padrones, guardándosele su hidalguía, y la posesión que tenía de tal, no ha podido conseguirlo: atento a lo cual, y no ser justo que lo referido se tolere, por tanto y para su remedio: a V. A. pido y suplico se sirva, habiendo por cierta y verdadera en lo que baste la relación de esta demanda, declarar a mi parte por hijodalgo notorio de casa y solar conocido, y haber estado juntamente con su padre y abuelo en la posesión de no pechar ni contribuir con pechos algunos, ni derramas reales, ni concejiles con que pechan y contribuyen los hombres buenos llanos pecheros: condenando al concejo de la nominada villa de Manzanares, y al vuestro fiscal a que de ahora en adelante le guarden todas las exenciones, franquezas y libertades que como a tal hijodalgo le corresponden; y en su consecuencia le quiten, tilden y borren de los padrones en que le tengan anotado en clase de pechero, y no le vuelvan a incluir en ellos, ni a repartirle lo que es propio del estado llano, restituyéndole inmediatamente a las prendas que por los referidos pechos le han sido tomadas, o en su defecto el valor de ellas; pues para que así todo se provea y mande, forme el expediente e intento el recurso, que sean más oportunos en justicia que pido costas, etc. y juro.

\section{Demanda del concejo contra el hidalgo}

$$
\text { M. P. S. }
$$

F. en nombre del concejo, justicia y regimiento de la villa de Manzanares, como más haya lugar por derecho, demando a D. Francisco de León y Luna, vecino de ella y digo: Que siendo éste hombre llano pechero, y habiéndolo sido igualmente su padre, abuelo y demás ascendientes por línea derecha de varón sin cosa en contrario, y de consiguiente pechado y contribuido con todos los hombres buenos llanos pecheros, sin que por razón de hidalguía se haya exceptuado alguno de ellos: el referido D. Francisco, sirviéndose de documentos supuestos, y de informaciones falsas por el mucho valimiento que ha tenido y tiene, ha podido introducirse al goce y reputación de hijodalgo, lo cual resulta en muy grave perjuicio de los demás vecinos, del bien común y del patrimonio real; por tanto, y para su remedio: a V. A. suplico se sirva admitir esta demanda 
cuanto ha lugar por derecho, y habiendo su relación por cierta y verdadera en la parte que baste, declarar al D. Francisco de León y Luna por hombre llano pechero, y haber estado en la posesión de tal, condenándole a que peche y contribuya en los pechos, derramas y contribuciones con que pechan y deben pechar y contribuir los demás hombres buenos llanos pecheros de la nominada villa: y a que sirva y ejerza los oficios y cargas que a estos son correspondientes, haciendo en el asunto las declaraciones y condenaciones que más convengan en justicia, que pido costas, etc. y juro.

Otro sí: a efecto de esta demanda se haga saber: Suplico a V. A. se sirva mandar despachar real provisión de emplazamiento contra el expresado D. Francisco de León y Luna: pido ut supra.

Otro sí: en atención a que éste, durante el pleito, debe pechar y contribuir como lo ejecutan los demás pecheros según la ley del Sr. D. Enrique: Suplico a V. A. sea servido mandar se libre real provisión con inserción de ella, para que el citado concejo la guarde, cumpla y ejecute: pido ut supra.

Otrosí, a V. A. suplico se sirva mandar que a su tiempo se haga igualmente saber la demanda al vuestro fiscal, para que salga a la voz y defensa de ella: pido ut supra.

\section{Auto}

Admítese esta demanda cuanto ha lugar en derecho: notifíquese al fiscal de S. M. y despáchese real provisión de emplazamiento, para hacerla saber a D. Francisco de León y Luna, y otra con inserción de la ley y pragmática del Sr. Rey D. Enrique, a fin que el concejo, justicia y regimiento de la villa de Manzanares haya y tenga por ahora y durante este pleito al mismo D. Francisco, como a los demás vecinos del estado general repartiéndole, y en caso necesario sacándole prendas: y de haberlo así ejecutado, remita testimonio a la Sala dentro de quince días. Proveído por los señores alcaldes del crimen y de hijosdalgo de la Audiencia y Chancillería de S. M. que lo vieron y rubricaron. Granada, etc.

\section{Contestación}

$$
\text { M. P. S. }
$$

F. en nombre de D. Francisco de León y Luna, vecino de la villa de Manzanares, como más haya lugar en derecho, y sin perjuicio de otro que a mi parte competa, de que protesto usar según le convenga, digo: Se ha hecho saber a mi parte una demanda puesta en esta Corte por el concejo, justicia y regimiento de ella, en que relacionando que aquél, su padre y abuelo, con los demás ascendientes, han sido hombres buenos, llanos y pecheros: y que indebidamente se ha introducido mi parte al estado de los hijosdalgos, concluye pretendiendo que a éste se declare por tal pechero, y se le condene a que peche y contribuya, y a que sirva los oficios correspondientes al estado general. Y en justicia V. A. se ha de servir absolver, y dar por libre a mi parte de la propuesta demanda, im- 
poniendo perpetuo silencio a la contraria, declarando a aquél por hijodalgo notorio de sangre, casa y solar conocido, condenando al concejo a que le haya, y tenga por tal, y a que le vuelva y restituya todas las cantidades que le haya exigido, y mandado y no le impida el uso y blasón de sus armas donde tenga por conveniente, le anote como hijodalgo en los padrones, le proponga para los oficios propios de la nobleza, con condenación de costas: que así todo es de hacer, atendiendo que mi parte es hijodalgo notorio de sangre, casa y solar conocido, como hijo legítimo de D. Juan Martínez de León, y de Doña Josefa Sánchez de Luna: nieto de Gabriel Martín de León, y de Francisca Díaz: segundo nieto de Alonso Martín de León, y de Catalina Alonso: tercero nieto de Francisco de León y de María Sánchez, vecinos todos de la expresada villa de Manzanares: cuarto nieto de Alonso de León y de Isabel Martín, que lo fueron de la de CubiIlos: y quinto nieto de García de León y de Teresa Garay, naturales del lugar de Cobrana en el reino y montaña de León, dueño y poseedor de la casa solar de este apellido, que era fuerte y murada de mucha nobleza solariega; la cual poseyeron igualmente todos los ascendientes de mi parte por varonía y mayoría, y como tales siempre fueron habidos y comúnmente reputados de inmemorial tiempo, sin cosa en contrario, portándose con el lustre y decencia correspondiente a su estado y calidad, manteniendo armas y caballos, y concurriendo e todos los actos y funciones de los demás hijosdalgos: y cuando casaron, lo ejecutaron con personas del mayor lustre y esplendor, conservando capillas y enterramientos con los escudos y armas de su apellido, iguales a los de las casas principales de su morada: siendo reservados y exentos de los pechos, derramas, cargas y repartimientos reales y concejiles con que contribuyen y pagan los hombres buenos llanos pecheros: y gozando de los oficios nobles que son propios de los hijosdalgos, por serlo verdaderamente, y no por otro algún respeto, sin que pueda acreditarse acto alguno en contrario; y así la demanda del concejo es absolutamente injusta y despreciable: por tanto y sin que sea visto dejar consentida especie alguna perjudicial a mi parte: Suplico a V. A. se sirva proveer y determinar a su favor, como aquí se contiene, y es justicia, que pido costas, etc.

Otro sí: protesto suspender el juicio de la propiedad según a mi parte sea conveniente: a V. A. suplico se sirva admitir esta protesta: pido ut supra.

Otro sí: en atención a que de lo expuesto en lo principal de este escrito se convence que mi parte es de casa y solar, y que éste y sus ascendientes han estado en posesión de hijosdalgo; cuyas circunstancias le exoneran de pechar durante el pleito: a V. A. suplico sea servido mandar recoger la real provisión enriqueña, y que para ello se libre la correspondiente: pido ut supra.

\section{Auto}

Traslado de todo. Granada, etc. 


\section{Réplica del concejo}

M. P. S.

F. en nombre del concejo, justicia y regimiento de la villa de Manzanares, en el pleito con D. Francisco de León y Luna, vecino de ella, digo: Que sin embargo de lo que en nombre de éste se alega en el pedimento de su contestación proveído en tal día: V. A., justicia mediante ha de ser servido resolver, y determinar como por mi parte está pretendido en el de su demanda, y aquí se contendrá: que así es de hacer por lo general que del proceso resulta. A que se llega que la contraria no es hijo, nieto ni descendiente de los que propone; cuya filiación niego en toda forma, como afectada y supuesta. Además que caso (no permitido) fuese cierta, le obstaría el no ser, como no es legítima, sino bastarda y adulterina, de modo que todas las personas que la contraria figura por sus ascendientes, fueron habidos de dañados y punibles ayuntamientos: y por esta causa tienen una notoria incapacidad para la hidalguía: siendo incierto que en algún tiempo hubiesen gozado la posesión de tales, ni tampoco los privilegios y exenciones que se refieren, y no podrán justificarse. Siendo de entender, que en las montañas de León ni hay, ni jamás ha habido casa solariega del apellido de la contraria: y cuando la hubiese, sería de hombres buenos llanos pecheros, como él y sus ascendientes han sido y son en Manzanares, donde tienen su origen y naturaleza: mediante lo cual, todo lo que D. Francisco de León y Luna alega, carece de realidad, y debe despreciarse; por tanto: a $\mathrm{V}$. A. suplico se sirva proveer, y determinar como en este escrito se contiene y corresponde en justicia que pido, etc.

Otro sí digo: Se ha conferido traslado a mi parte de la solicitud hecha de contrario en orden al recogimiento de la real provisión enriqueña. $Y$ mediante a que el caso no es como se figura, porque a la contraria no favorece de manera alguna la ley en sus limitaciones; por tanto e impugnando desde luego la referida pretensión: Suplico a V. A. se sirva denegarla: pido ut supra.

\section{Auto}

Traslado y autos. Granada, etc.

\section{Escrito de conclusión del hidalgo}

M. P. S.

F. en nombre de D. Francisco de León y Luna, vecino de la villa de Manzanares, en los autos con el concejo, justicia y regimiento de ella, digo: Que negando y contradiciendo lo perjudicial a mi parte, concluyo sin embargo de lo alegado de contrario en su pedimento de tal día: a V. A. suplico se sirva haberlos por conclusos, y para ello, etc.

\section{Auto}

Por su parte y traslado. Granada, etc. 
Escrito de conclusión del concejo

M. P. S.

F. en nombre del concejo, justicia y regimiento de la villa de Manzanares, en el pleito con D. Francisco de León y Luna, vecino de ella, digo: Que negando, y contradiciendo lo perjudicial a mi parte, concluyo sin embargo del pedimento presentado por la contraria en tal día: Suplico a V. A. se sirva haberlo por concluso, y para ello, etc.

\section{Auto}

Por su parte, y concluso. Granada, etc.

Respuesta del fiscal de S. M.

El fiscal de S. M. ha visto estos autos: y en consideración al estado que tienen, concluye sin embargo. Granada, etc.

\section{Auto recibiendo el pleito a prueba}

En la ciudad de Granada, etc. visto por los señores alcaldes del crimen y de hijosdalgo de la Audiencia y Chancillería de S. M. el pleito que en esa Corte está pendiente entre el concejo, justicia y regimiento de la villa de Manzanares, y el fiscal de S. M. de la una parte, y D. Francisco de León y Luna, vecino de ella, de la otra, sobre la filiación e hidalguía de éste, y lo demás en él contenido, dijeron: lo recibirían, y recibieron a prueba en forma y con término de los ochenta días de la ley comunes a las partes, para que en ellos hagan sus probanzas; y así lo proveyeron y rubricaron.

\section{Auto decisivo del artículo de recogimiento de la enriqueña}

En la ciudad de Granada, etc. visto por los señores alcaldes del crimen y de hijosdalgo de la Audiencia y Chancillería de S. M. el pleito que en esta Corte está pendiente entre el concejo, justicia y regimiento de la villa de Manzanares, y el fiscal de S. M. de la una parte, y D. Francisco de León y Luna, vecino de ella, de la otra, sobre la filiación e hidalguía de éste, y lo demás en él contenido: y el artículo formado por el mismo D. Francisco en segundo otro sí de su pedimento de contestación, a efecto de que se recoja la real provisión enriqueña despachada a la parte del citado concejo: de que se hizo relación a los expresados señores, dijeron: declaraban, y declararon no haber lugar al recogimiento de ella; y así lo proveyeron y rubricaron.

Si esta providencia se apela, se sigue la instancia del modo que se dirá cuando se trate del recurso de apelación de la definitiva: y el término de prueba queda suspenso hasta la confirmación, o revocación de la Sala de señores oidores desde cuando empieza a correr. Si no se hacen probanzas, con la nota de la publicación, tiene estado el pleito de tomarse la última resolución: y si se practican diligencias, se alega de bien probado, y se concluye como en cualquiera otro negocio de discusión ordinaria; y la sentencia definitiva dice de esta manera. 


\section{Sentencia definitiva}

En el pleito que es entre el fiscal de S. M. y el concejo, justicia y regimiento de la villa de Manzanares, y F. su procurador en su nombre de una parte, y de la otra D. Francisco de León y Luna, vecino de ella, y F. su procurador en el suyo de la otra.

Fallamos: que el fiscal de S. M. y el citado concejo, justicia y regimiento de Manzanares no provocaron su acción y demanda como les convenía: declarámosla por no probada, y que el referido D. Francisco de León y Luna lo hizo cumplidamente de sus excepciones y defensas: dámoslas y pronunciámoslas por bien probadas, en cuya consecuencia le debemos declarar, y declaramos por hijodalgo de casa y solar conocido de sí, sus padres y abuelos, como descendientes de la casa solariega de su apellido de León, y haber estado, y está en sus respectivos tiempos, y en las partes y lugares donde vivieron y moraron, viven y moran en la posesión de tales hijosdalgos, libres y exentos de pechar y contribuir en los pechos y tributos de pecheros reales y concejiles: y mandamos les sean guardadas todas las honras, franquezas, libertades y exenciones que se acostumbran guardar a los otros nobles hijosdalgos de estos reinos y señoríos: y debemos condenar, y condenamos al concejo, justicia y regimiento de la villa de Manzanares, y a todos los otros concejos de las demás ciudades, villas y lugares de estos reinos y señoríos de S. M. donde el D. Francisco de León y Luna viviere y morare, tuviere bienes y hacienda: a que ahora, y de aquí adelante no le echen, ni repartan pedidos, moneda, servicios, ni otros pechos o contribuciones algunas reales, ni concejiles con los hombres buenos pecheros, sus vecinos, en que los hijosdalgos no pechan, ni pagan, ni son tenidos de pechar y pagar: ni les prendan, ni tomen algunos de sus bienes, prendas ni maravedíes por ellos, ni por cosa alguna de ellos. Otro sí: condenamos al dicho concejo, justicia y regimiento de Manzanares, y le mandamos vuelva y restituya, haga volver y restituir, dar y entregar al mencionado D. Francisco de León y Luna, o a quien para ello su poder hubiere, todas y cualesquier prendas, bienes y maravedíes que por razón de los dichos pechos le hayan sido tomadas, prendadas o embargadas desde antes que este pleito se principiase, como después, tales y tan buenas: y en su defecto, su valor y estimación, lo que cumpla dentro de quince días siguientes al requerimiento con la carta ejecutoria que de esta sentencia se despache, quitándole y borrándole de cualesquiera padrones de pecheros en que estuviese puesto y empadronado, y no lo poniendo, ni consintiendo ponerlo más en ellos: e imponemos perpetuo silencio al fiscal de S. M. y a dicho concejo de Manzanares, y a todos los de las otras ciudades, villas y lugares de estos reinos y señoríos, para que ahora, ni en adelante no inquieten, perturben, ni molesten más al nominado D. Francisco de león y Luna, sobre y en razón de la propiedad solariega de su hidalguía y posesión vel quasi de ella: y sin costas por esta nuestra sentencia definitiva así lo pronunciamos y mandamos.

\section{Pedimento de apelación del concejo}

M. P. S.

F. en nombre del concejo, justicia y regimiento de la villa de Manzanares, en los autos con D. Francisco de León y Luna, vecino de ella digo: Que en ellos se ha pronunciado sentencia definitiva por los vuestros alcaldes de hijosdalgo en 
perjuicio de mi parte: de la que apelo, y me presento en grado de apelación; por tanto: Suplico a V. A. se sirva admitir esta presentación y mandar que para hacerla en forma se me entregue el proceso, y en el ínterin protesto no corra a mi parte término, ni pare el juicio: pido justicia, etc.

\section{Pedimento formalizando la apelación}

$$
\text { M. P. S. }
$$

F. en nombre del concejo, justicia y regimiento de la villa de Manzanares, en los autos con D. Francisco de León y Luna, vecino de ella, digo: Que la sentencia definitiva pronunciada por los vuestros alcaldes de hijosdalgo en tal día, es nula, y como tal, V. A. se ha de servir declararla, o al menos revocarla como injusta, determinando en todo a favor de mi parte, según éste tiene pretendido, y aquí se contendrá; pues así corresponde a los méritos que produce el expediente: porque según ellos, no admite duda que D. Francisco de León y Luna, sus padres y ascendientes son, y siempre han sido hombres buenos llanos pecheros, sin haber gozado jamás los fueros de la hidalguía, ni habérseles distinguido como tales en los pueblos donde han vivido y poseído bienes y hacienda, y así todo lo que se propone acerca de la casa y solar del apellido de León en las montañas, y de proceder de ella el D. Francisco, es supuesto y figurado, y no tiene prueba apreciable en el proceso: por lo cual la sentencia definitiva apelada merece que la rectitud del tribunal la revoque; a cuyo fin suplico a $\mathrm{V}$. A. se sirva proveer y determinar como aquí se contiene, y es justicia, que pido costas, etc.

\section{Pedimento solicitando la confirmación de la sentencia}

$$
\text { M. P. S. }
$$

F. en nombre de D. Francisco de León y Luna, vecino de la villa de Manzanares, en los autos con el concejo, justicia y regimiento de ella, y el vuestro fiscal de esta Corte, digo: Que la sentencia definitiva pronunciada tal día por los vuestros alcaldes de hijosdalgo, es justa, y como tal se ha de servir V. A. confirmarla, condenando en costas a la contraria, y determinando en favor de mi parte, como en este escrito se propondrá: que así es de hacer, reflexionando que la hidalguía, filiación y distinción de mi parte y sus mayores por línea recta de varón, es notoria dentro del proceso, sin embargo de las exageraciones que hace en sus alegatos el concejo de Manzanares; cuyas defensas no llevan otro espíritu que el de la emulación, y por lo mismo, conociéndolas la Sala de hijosdalgo, las despreció, y pronunció en favor de mi parte la providencia definitiva apelada, a que corresponde que ésta se confirme con las costas de la instancia: por tanto, y sin que sea visto dejar consentida especie alguna perjudicial, a $\mathrm{V}$. A. suplico se sirva proveer y determinar como aquí se contiene, y es justicia que pido, etc. 


\section{Pedimento de conclusión}

M. P. S.

F. en nombre del concejo, justicia y regimiento de la villa de Manzanares, en los autos con D. Francisco de León y Luna, vecino de ella digo: Que negando y contradiciendo lo perjudicial a mi parte concluyo sin embargo de lo alegado en contrario en su pedimento de tal día: suplico a V. A. se sirva haberlos por conclusos, y para ello, etc.

\section{Respuesta del fiscal de S. M.}

El fiscal de S. M. ha visto estos autos, y reproduciendo lo que anteriormente tiene expuesto en ellos con atención a su estado, concluye sin embargo. Granada, etc.

\section{Sentencia de vista}

En el pleito que es entre el fiscal de S. M. y el concejo, justicia y regimiento de la villa de Manzanares, y F. su procurador en su nombre de la una parte: y de la otra D. Francisco de León y Luna, vecino de ella, y F. su procurador en el suyo.

Fallamos: que los alcaldes de hijosdalgo de esta Corte que de él conocieron, en la sentencia definitiva que pronunciaron a tantos de tal mes, por la que declararon al D. Francisco por hijodalgo de casa y solar conocido de sí, sus padres y abuelos, como descendientes de la casa solariega de su apellido de León, y haber estado, y estar en sus respectivos tiempos, y en las partes, y lugares donde vivieron y moraron, viven y moran, en la posesión de tales hijosdalgos, libres y exentos de pechar y contribuir en los pechos y tributos de pecheros reales y concejiles: y mandaron les sean guardadas todas las honras, franquezas, libertades y exenciones que se acostumbran guardar a todos los nobles, hijosdalgos de estos reinos y señoríos: condenando al concejo, justicia y regimiento de la villa de Manzanares, y a todos los otros concejos de las demás ciudades, villas y lugares de estos reinos y señoríos de S. M. donde el D. Francisco de León y Luna viviere y morare, tuviere bienes y hacienda a que ahora y de aquí adelante no le echen, ni repartan pedidos, monedas, ni contribuciones algunas reales ni concejiles con los hombres buenos pecheros sus vecinos, en que los hijosdalgos no pechan, ni pagan, ni son tenidos de pechar y pagar: ni les prendan, ni tomen algunos de sus bienes, prendas ni maravedíes por ellos, ni por cosa alguna de ellos.

Otro sí: condenaron al dicho concejo, justicia y regimiento de Manzanares, y le mandaron volviese y restituyese, hiciese volver y restituir dar y entregar al nominado D. Francisco de León y Luna, o a quien para ello su poder hubiese, todas y cualesquier prendas, bienes y maravedíes que por razón de los dichos pechos y tributos de pecheros le han sido tomadas, prendadas o embargadas desde antes que este pleito se principiase, como después, tales y tan buenas: y en su defecto, su valor y estimación, lo que cumpla dentro de quince días siguientes al requerimiento con la carta ejecutoria que de esta sentencia se des- 
pache, quitándole y borrándole de cualesquiera padrones de pecheros en que estuviese puesto y empadronado, y no lo poniendo, ni consintiendo ponerlo más en ellos: e imponiendo perpetuo silencio al fiscal de S. M. y a dicho concejo de Manzanares, y todos los de las otras ciudades, villas y lugares de estos reinos y señoríos, para que ahora, ni en adelante no inquieten, perturben, ni molesten más al nominado $\mathrm{D}$. Francisco de León y Luna, sobre, y en razón de la propiedad solariega de su hidalguía y posesión vel quasi de ella: juzgaron y pronunciaron bien: confirmamos la referida sentencia, la cual mandamos se guarde, cumpla y ejecute en todo y por todo, según y como en ella se contiene: y sin costas por esta nuestra sentencia definitiva así lo pronunciamos y mandamos.

\section{Pedimento de suplicación del concejo}

$$
\text { M. P. S. }
$$

F. en nombre del concejo, justicia y regimiento de la villa de Manzanares, en los autos con D. Francisco de León y Luna, vecino de ella, suplico de la sentencia de vista pronunciada en ellos tal día, por algunos de vuestros oidores, y hablando debidamente digo: Es de reformar, suplir y enmendar; y para poderlo hacer más en forma con el abogado de mi parte a V. A. suplico se sirva mandar se me entreguen los autos: pido justicia, etc.

\section{Decreto}

Traslado. Pública. Granada, etc.

\section{Pedimento de suplicación en forma}

$$
\text { M. P. S. }
$$

F. en nombre del concejo, justicia y regimiento de la villa de Manzanares, en los autos con D. Francisco de León y Luna, vecino de ella, suplicando en forma de la sentencia definitiva pronunciada por algunos de vuestros oidores, y hablando debidamente, digo: Es de reformar, suplir y enmendar, proveyendo y determinando a favor de mi parte, según tengo pretendido en las instancias anteriores, y en este escrito se expresará: que así es de hacer con respecto al mérito y circunstancias del proceso. A que se llega por convencimiento de que la familia de D. Francisco de León y Luna es, y siempre ha sido de las más llanas de Manzanares, que algunos individuos de ella pretendieron ser recibidos al estado de los hijosdalgos, y otros solicitaron la continuación en diversos pueblos dentro y fuera de la comarca, y no pudieron conseguirlo, habiéndoseles denegado en todos los tiempos sus recursos: mediante lo cual, se deduce que la que el mismo D. Francisco llama posesión, no es otra cosa que una introducción mañosa y artificial, procedente de sus respetos y conexiones con los capitulares, y hombres de la primera clase de la república, la que de ningún modo le aprovecha, por tanto, a V. A. suplico se sirva proveer y determinar en favor de mi parte como aquí se contiene, por ser de justicia, que pido costas. etc. y ofrézcome a probar. 


\section{Pedimento solicitando la sentencia de vista}

M. P. S.

F. en nombre de D. Francisco de León y Luna, vecino de la villa de Manzanares, en los autos con el concejo, justicia y regimiento de ella, y el vuestro fiscal de esta Corte, digo: Que la sentencia de vista pronunciada tal día por algunos de vuestros oidores, es justa, y como tal, V. A. se ha de servir confirmarla, determinando en favor de mi parte, y condenando en costas la contraria; pues así debe hacerse sin embargo de cuanto se alega en su pedimento de tal día; porque aunque sea cierto que algún pariente de mi parte no consiguiese el recibimiento al estado de hijosdalgo, consistió la denegación en que había dejado pasar más de diez años después que se avecindó en el pueblo: y con este atraso de tiempo intentó el recurso; pero luego después, usando de su derecho, ejecutorió su hidalguía en la Real Chancillería de Valladolid. Y en orden a las continuaciones de otros parientes, se padece equivocación, y no se acreditará este particular por el concejo de Manzanares, mediante que en la ascendencia por varonía de mi parte no ha habido alguno que no haya gozado los fueros y privilegios de la nobleza; en cuyos términos la sentencia de vista es arreglada al mérito de la causa, y debe por lo mismo despreciarse la suplicación interpuesta de ella con las costas del recurso; a cuyo fin suplico a V. A. se sirva proveer y determinar en favor de mi parte como aquí se contiene, y es justicia, que pido, etc.

Otro sí: en atención a que la prueba que de contrario se ofrece, es maliciosa y dirigida a dilatar el pleito, para que mi parte continúe pechando en fuerza de la real provisión enriqueña, la contradigo en forma: Suplico a V. A. sea servido denegarla: pido ut supra.

En la cláusula con que finaliza el pedimento de suplicación en forma, se ve el modo de ofrecerse nuevas probanzas en las instancias de vista y revista: las cuales, si se consienten expresamente, o aunque se contradigan, el Tribunal Superior estima convenientes; se admiten y se reciben los autos a prueba. Y cuando la contradicción es fundada, y la Sala forma idea que el artículo conspira a dilatar, o por otro capítulo es inadmisible, deniega absolutamente la prueba, o la reserva para definitiva, y manda continuar la sustanciación.

\section{Pedimento de conclusión}

M. P. S.

F. en nombre del concejo, justicia y regimiento de la villa de Manzanares, en los autos con D. Francisco de León y Luna, vecino de ella, digo: Que negando y contradiciendo lo perjudicial, concluyo sin embargo de lo alegado de contrario en lo principal de su pedimento de tal día: a V. A: suplico se sirva haberlos por conclusos, y para ello, etc.

\section{Respuesta del fiscal}

El fiscal de S. M. ha visto esto autos, y atento a su estado, concluye sin embargo. Granada, etc. 


\section{Sentencia de revista}

En el pleito que es entre el fiscal de S. M. y el concejo, justicia y regimiento de la villa de Manzanares, y F: su procurador en su nombre de la una parte: y de la otra D. Francisco de León y Luna, vecino de ella, y su procurador en el suyo.

Fallamos: que la sentencia de vista dada y pronunciada en tal día por algunos de nos los oidores de la Audiencia de S. M., por la cual confirmamos la de los alcaldes de hijosdalgo de ella de tal día, en que declararon al D. Francisco por hijodalgo de casa y solar conocido de sí, sus padres y abuelos, como descendientes de la casa solariega de su apellido de León, y haber estado y estar en sus respectivos tiempos, y en las partes donde vivieron y moraron, viven y moran en la posesión de hijosdalgo, libres y exentos de pechar y contribuir en los pechos y tributos de pecheros reales y concejiles: y mandaron les sean guardadas todas las honras, franquezas, libertades y exenciones que se acostumbran guardar a los otros nobles hijosdalgos de estos reinos y señoríos: condenando al concejo, justicia y regimiento de la villa de Manzanares, y a todos los otros concejos de las demás ciudades, villas y lugares de estos reinos y señoríos de S. M. donde el D. Francisco de León y Luna viviere y morare, tuviere bienes y hacienda: a que ahora y de aquí adelante no le echen, ni repartan pedidos, monedas, servicios, ni otros pechos, ni contribuciones algunas reales, ni concejiles con los hombres buenos pecheros, sus vecinos, en que los hijosdalgos no pechan, ni pagan, ni son tenidos de pechar y pagar: ni les prendan, ni tomen algunos de sus bienes, prendas, ni maravedíes por ellos, ni por cosa alguna de ellos. Otro sí: condenaron al dicho concejo, justicia y regimiento de Manzanares y le mandaron volviese y restituyese, hiciese volver y restituir, dar y entregar al nominado D. Francisco de León y Luna, o a quien para ello su poder hubiese, todas y cualesquier prendas, bienes y maravedíes que por razón de los dichos pechos y tributos de pecheros le hayan sido tomadas, prendadas o embargadas desde antes que este pleito se principiase, como después, tales y tan buenas: y en su defecto su valor y estimación, lo que cumpla dentro de quince días siguientes al requerimiento con la carta ejecutoria que de esta sentencia se despache, quitándole y borrándole de cualesquiera padrones de pecheros en que estuviese puesto y empadronado, y no lo poniendo, ni consintiendo ponerlo más en ellos, e imponiendo perpetuo silencio al fiscal de S. M. y a dicho concejo de Manzanares y todos los de las otras ciudades, villas y lugares de estos reinos y señoríos, para que ahora, ni en adelante no inquieten, perturben, ni molesten más al nominado D. Francisco de León y Luna, sobre, y en razón de la propiedad solariega de su hidalguía y posesión vel quasi de ella: fue y es buena, justa y derechamente dada y pronunciada, y como tal, sin embargo de lo contra ella dicho y alegado en este grado de suplicación, la debemos confirmar, y confirmamos: la cual mandamos se guarde, cumpla y ejecute en todo y por todo, según y como en ella se contiene: y sin costas por esta nuestra sentencia definitiva en grado de revista, así lo pronunciamos y mandamos.

FIN 